\title{
ELUCIDATION OF NOBLE METAL/FORMIC ACID \\ CHEMISTRY DURING DWPF FEED PREPARATION (U)
}

by

L. F. Landon

Westinghouse Savannah River Company

Savannah River Site

Aiken, South Carolina 29808

\section{DOE Contract No. DE-AC09-89SR18035}

This paper was prepared in connection with work done under the above contract number with the U. S.

Department of Energy. By acceptance of this paper, the publisher and/or recipient acknowledges the U. S. Government's right to retain a nonexclusive, royalty-free license in and to any copyright covering this paper, along with the right to reproduce and to authorize others to reproduce all or part of the copyrighted paper. 


\section{TECHNICAL REPORT}

to the

Westinghouse Savannah River Laboratory

Aiken, South Carolina

on

\section{ELUCIDATION OF NOBLE METAL/FORMIC ACID CHEMISTRY DURING DWPF FEED PREPARATION}

by

R. B. King, Regents' Professor and Principal Investigator "

A. D. King, Jr., Professor and Faculty Associate

N. K. Bhattacharyya, Post-Doctoral Fellow

Report 1

March, 1991

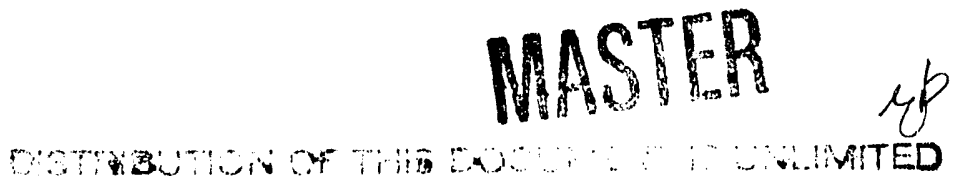




\section{PRELIMINARY EVALUATION OF NOBLE METALS AS CATALYSTS \\ FOR THE DECOMPOSITION OF FORMIC ACID}

\section{AEROBIC CONDITIONS}

R. B. King, A. D. King, Jr., N. K. Bhattacharyya

Department of Chemistry

University of Georgia

Athens, Georgia 30602

\section{Report prepared for the Savannah River Laboratory March, 1991}

Revised after discussions with C. M. King, March 7-8, 1991

Abstract:

The noble metal compound $\mathrm{RuCl}_{3} \cdot \mathrm{HH}_{2} \mathrm{O}, \mathrm{RhCl}_{3} \cdot 3 \mathrm{H}_{2} \mathrm{O}, \mathrm{PdCl}_{2}, \mathrm{AgNO}_{3}$, $\mathrm{OSCl}_{3}$, $\mathrm{IrCl}_{3} \cdot 3 \mathrm{H}_{2} \mathrm{O}, \mathrm{K}_{2} \mathrm{PtCl}_{4} \mathrm{O}$ and $\mathrm{HuCl}_{4} \cdot \mathrm{HH}_{2} \mathrm{O}$ have been evaluated as catalyate for the decomposition/dehydration/oxidation of formic acid in the presence of air. The course of the seaction was foilowed by monitoring the off gages for $\mathrm{CO}_{2}, \mathrm{CO}, \mathrm{O}_{2}$, and $\mathrm{H}_{2}$ by gas chromatogra iy. The predominant reaction under these conditions was formic acid oxidation by atmospheric oxygen, which was catalyzed to varying extents by the $R \mathrm{R}, \mathrm{Rh}, \mathrm{Pd}, \mathrm{Ag}$, and Pt derivatives. The most catalytically active derivative was the Ir derivative, which also exhibited catalytie activity for the decomposition of formic acid to $\mathrm{H}_{2}$ and the dehydration of formic acid to co.

These preliminary observations nuggest that oxygen in air may be a useful inhibitor of formic acid decomposition and hydrogen generetion in nuclear waste compositions. Experimente are now in progreas to confirm that anaerobic conditione (nitrogen blanketed experiments) in fact favor hydrogen generation catalyzed by noble metals. 


\section{Introduction}

The imulated feed preparation for the glase melter operation at Weatinghouse Savannah River Laboratory (WSRL)/TWX is now in pilot-acale campaigning in support. of the Defense waste Processing Facility (DWPF). In order to simulate the presence of transition metal figeion by-product, in actual high level nuclear waste, the four noble metale $\mathrm{Ru}, \mathrm{Rh}, \mathrm{Pd}$, and $\mathrm{Ag}$ as their chloride or nitrate salts are now being added to simulated DWPF sludge. Metal constituents in the oludge are reduced and, in most cases, solubilized by addition of formic acid. The primary reason for using formic acid rather ehan another acid is the reduction of $\mathrm{Hg}^{2+}$ to elemantal mercury for removal from the feed prior to glase melter aimulations. After formic addition, the mixture is heated at reflux at $101^{\circ} \mathrm{C}$ to bring the reaction to completion. During this heating period, recent campaigne at the INX pilot facility have observed gascous hydrogen in the off gases. The production of gaseous hydrogen during this etage of the preparation of the DWPF feed presents a major flre and explosion hazard during operation of the DWPF. Methode for eliminating this unwanted hydrogen production are therefore desperately needed.

The general objectives of this research project are the elucidation of the origin of this hydrogen production and the development of practleal methode for its inhibition. This initial phase of this research involved scouting noble matals of interest as catalyote for formic acid decomposition. In order to imulate process conditions the noble matale of intereat in their most fo Ally available soluble forms (Table 1) were hated with pure formic acid at its boiling point. The course of reactione taking place was monitored by measuring the off gases by gas chromatography as a function of time. This study included both the noble motals of the $4 d$ transition series $R u, R h, P d$, and $A g$ and their $5 d$ traneition series congeners 0 , Ir, Pt, and Au, respectively. The $4 d$ traneltion motals are all found in uranium fission product, (Table 1) (1). The 5d transition metale wero included in this study in order to explore the differences in catalytic activity between analogous 4d and 5d trancition metale.

\section{Backaround}

The following reactione of formic acid are of interent in the context of this study:

\section{(a) Decomposition:}

$$
\mathrm{HCO}_{2} \mathrm{H} \longrightarrow-\mathrm{H}_{2}+\mathrm{CO}_{2}
$$

This is the source of the unwanted hydrogen production during nuclear waste proces- 
sing using formic acid. This process can be recognized by the production of equal quantities of $\mathrm{H}_{2}$ and $\mathrm{CO}_{2}$ in the off gases. There are precedents in the technical literature for the catalyols of this reaction by oluble derivatives of a. number of metal including ruthenium (2) and rhodium (3).

(b) Dehydration:

$$
\mathrm{HCO}_{2} \mathrm{H}-\cdots-\mathrm{H}_{2} \mathrm{O}+\mathrm{CO}
$$

This procese can be recognized by the presence of co in the off gases. However, if this reaction occurs in the presence of a metal forming a etable carbonyl derivative, the co can bond to the metal to form a carbonyl. Examples of matale forming carbonyls with formi: acid include rhenium $[4]$, ruthenium $(5,6,7,8,9\}, 5$ hodium $[8,9,10\}$, oamium $[8,9]$, iridium $[8,9]$, and platinum $[8,9]$.

(c) Metal Reduction:

$$
\mathrm{M}^{\mathrm{n}}+\mathrm{HCO}_{2} \mathrm{H}-\ldots--\rightarrow \mathrm{M}^{(\mathrm{n}-2)+}+2 \mathrm{H}^{+}+\mathrm{CO}_{2}
$$

This process can be recognized by the production of $\mathrm{CO}_{2}$ not accompanied by the production of $\mathrm{H}_{2}$ or the depletion of $\mathrm{O}_{2}$. Each equivalent of $\mathrm{CO}_{2}$ corresponds to a two-electron reduction.

\section{(d) Oxidation:}

$$
2 \mathrm{HCO}_{2} \mathrm{H}+\mathrm{O}_{2}--\infty-2 \mathrm{H}_{2} \mathrm{O}+2 \mathrm{CO}_{2}
$$

This procese can be recognized by the production of $\mathrm{CO}_{2}$ in the off gases at twice the rate of depletion of $\mathrm{O}_{2}$ in the off gaees. In order to def ct clearly the origin of the $\mathrm{CO}_{2}$ produced in the interaction of formic acid with transition metals, the figures show a plot of the wum $\left(\mathrm{CO}_{2}\right)+2\left(\mathrm{O}_{2}\right)$. If this line is horizontal, then all of the $\mathrm{CO}_{2}$ produced ariees from formic acid oxidation in accord with the fact that two equivalents of $\mathrm{CO}_{2}$ are produced for each equivalent of $\mathrm{O}_{2}$ consumed in the oxidation of formic acid according to equation 4 . If this line moves upward as the reaction proceeds, then there are eources of $\mathrm{CO}_{2}$ other than formic acid oxidation such as decomposition (equation 1 ) or metal reduction (equation 3). The oxidation of formic acid can be suppressed by running the experiment in an inert atmosphere such as nitrogen. The oxidation of formic actd is known (11) to be catalyzed by giant palladium clusters.

The formate chemietry of some of the noble metale is of interest. One characteristic of the carboxylate chemietry of many of the od and 5d transition motals is the tendency to form binuclear carboxylates with the general etructure I containing four carboxylate bridges between a palr of motal atoms. In wost cases there is a direct metal-metal bond. The axial positions of this so-called "lantern" structure are Lowis acidic and can complex with beses $[12,23,14]$. Rhodlum readlly forms 
rhodium(II) carboxylates with the general formula $R_{2}\left(O_{2} \mathrm{CR}\right)_{4}(22,13,14)$. Undex normal reaction conditione ruthenium forme mixed oxidation state Ru(II)$-R u(I I I)$ carboxylates such as $R_{2}\left(\mathrm{O}_{2} \mathrm{CR}\right)_{4} \mathrm{Cl}(15,16)$ but under reducing. conditione pure Ru(II) carboxylates $R u_{2}\left(O_{2} C R\right)_{4}(17)$ can aleo be lormed. Ruthenium also form some trinuclear carboxylates such as the formate $\mathrm{Ru}_{3} \mathrm{O}\left(\mathrm{O}_{2} \mathrm{CH}\right)_{6}^{+}$with an oxo-conterad $R u_{3}$ triangle with two formate bridges on each edge of the triangle (II) (18).

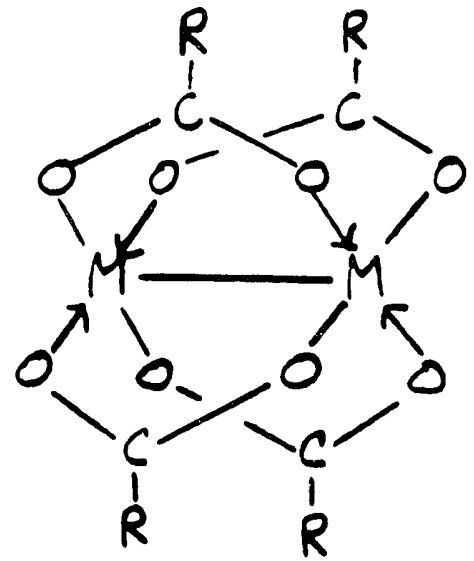

$\mathbf{I}$

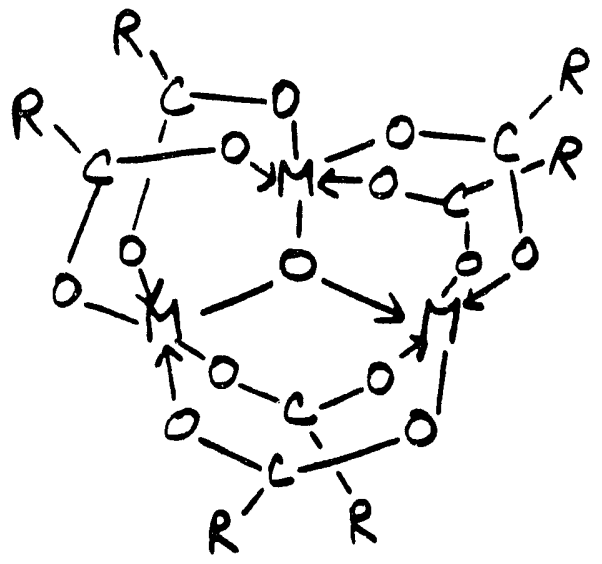

II

\section{Experimentel Mnthode}

Hydrogen andyee were pertormed ueing a Varian $90 p$ gav chromatograph. The hydrogen peak was eluted on $8^{\circ} \times 1 / 4^{\prime}$ column packed with a $40 / 60 \mathrm{mesh} 13 \times \mathrm{mole}-$ cular sieve material obtained from varian corporation using argon as the carrier gas. The column temparature was malntalned at $80^{\circ} \mathrm{C}$. Carbon monoxide, carbon dioxide, and other gaees were monitored ueing a rlaher Model 1200 gae partitioner. The gases were separated on the besis of thelr elas anc polarity by means of two columne, a 6.5 ft. $80 / 100$ moeh columpak pQ and an 11 ft. $13 x$ molecular oleve colums mounted in series using helium as the carrier gas. The temperatures of both columne were malntalnod at $50^{\circ} \mathrm{C}$.

A welghed quantity ( 50 to $150 \mathrm{mg}$ ) of the desired metal compound was placed in a $250 \mathrm{ml}$ ono-nock reaction flakk. To thle was added 40 mi of 885 formic acid. An adapter, conaloting of a r-folnt connoeted to a rubber eoptum and a rubber bulb, was attached to the flack. The solution was ot lered at room temperature. Gas samples were taken perlodically using a cas-loc oyringe and analyzed by gae chromatography. After a fow determinatione at roon temparaturo, the solution was rapidly warmed up to $\sim 80^{\circ}$ C. Samples of the gas phase were analyzed at varlous intervale 
during the period of interest. The amounts of reactants and products consumed and formed (expreseed as moles) were calculated from the pakk height data thus obtained using predetermined seneitivity factors. The reported etoichiometries of. the reactione discuseed in this report are based on the last data pointe taken.

Figures are appended showing the most intereating results obtained to date. In these figures the quantities $[\mathrm{CO}),\left[\mathrm{H}_{2}\right],\left[\mathrm{CO}_{2}\right],\left[\mathrm{O}_{2}\right],\left[\right.$ and $\left[\mathrm{CO}_{2}\right]+2\left[\mathrm{O}_{2}\right]$ (see above) are plotted as croved circles, triangles, circles, diamonds, and squares, respectively.

\section{Regulte}

\section{(a) Blank eun with pure formic acid in the absence of metale (Fioure il:}

Ae control experiment, pure formic acid was heated in the absence of metals and the production of $\mathrm{H}_{2}, \mathrm{CO}_{2}$, and $\mathrm{CO}$ monitored by gas chromatography. Formation of up to 0.2 moles each of $\mathrm{CO}$ and $\mathrm{CO}_{2}$ was obeerved. The formation of co indicates small amounte of formic acid dehydration in the absence of added metale (equation 2). The $\left(\mathrm{CO}_{2}\right)+2\left(\mathrm{O}_{2}\right)$ line for formie acid is nearly horizontal indicating that the primary cource of $\mathrm{CO}_{2}$ from pure formic acid upon heating in air is oxidation (equation 4 ). The amounts of lo and $\mathrm{Co}_{2}$ produced by heating pure formic acid in the abeence of motale although detectable are relatively minor. (b) Ruthenium (Pioure 21:

An old deliquesed sample of commercial hydrated ruthentum trichloride was used so that the amount of motal introduced into the syatem can be only crudely estimated as 0.9 moles. This produced 1.91 mmoles of $\mathrm{CO}_{2}$ with the consumption of 0.53 mmoles of $\mathrm{O}_{2}$ which accounts for 1.06 mmoles of the $\mathrm{CO}_{2}$ produced by oxidation (equation 4) leaving 0.85 moles of $\mathrm{CO}_{2}$ arieing from other sources. Some decomposition of formic acld is obeerved indicated by the production of 0.15 mnoles of $\mathrm{H}_{2}$ and by equation 1 accounting for another 0.15 moles of the $\mathrm{CO}_{2}$ produced. This leaves $1.91-1.06-0.15=0.70 \mathrm{mmoles}_{\text {of }} \mathrm{CO}_{2}$ to arise from reduction of the Ru. The ratio $0.7 / 0.9$ of $\left(\mathrm{CO}_{2}{ }^{\mathrm{red}}\right] /[\mathrm{Ru}]=0.78$ corresponde to an average of 1.56 electron reduction/Ru by equation 3 . However, reletively $11 t t l e$ can be inferred from thle observation for the following reasons (1) The amount of Ru introduced to only crudely known eince the osmple of hydrated ruthenium erichloride had dellquesced (2) comercial hydrated ruthontum trichloride is actually a crude mixture containing Ru nitrosyl derivativeo and Ru in oxidation etates other than +3 . No co was observed. However, co lo known $(5,6,7,8,9)$ to complex with Ru in formic acid media leading to Ru carbonyle. Boiling hydrated 
ruthenium trichloride with formic acid under conditions imilar to those used in this experiment is reported [8] to result in reduction of the Ru to give the yellow polymeric ruthenium carbonyl chloride (Ru(CO) ${ }_{2} \mathrm{Cl}_{2} l_{n}$ in which the oxidation state of the Ru is +2 .

(c) Rhodium (Figure 3):

Commercial hydrated rhodium trichloride was introduced corresponding to 0.12 moles of the metal. This produced 2.81 moles of $\mathrm{CO}_{2}$ with the concurrent consumption of 1.42 mmoles of $O_{2}$ indicating that essentially all of the $\mathrm{CO}_{2}$ was produced by a rhodium-catalyzed formic acid oxidation (equation 4). Only 0.01 mmoles of $\mathrm{H}_{2}$ was produced indicating that undur aeroble conditions formic acid decomposition (equation 1) catalyzed by $R h$ is negligible. In this experiment, which was the first performed, we did not measure co so no information is available on formic acid dehydration (equation 2 ). Some interesting color changes occurred during the course of this reaction. The initially pink solution became yellow and then green and finally blue as the reaction proceeded. This color change is suggestive of the formation of the known $(12,13,14)$ binuclear rhodium(II) formate $\mathrm{Rh}_{2}\left(\mathrm{O}_{2} \mathrm{CH}\right)_{4}$

(d) Paltadium (Figure 4): :

Commercial anhydrous palladium chloride was introduced corresponding to 0.20 mmoles of the metal. This produced a total of 0.60 mmoles of $\mathrm{CO}_{2}$ with the consumption of 0.20 mnoles of $\mathrm{O}_{2}$ accounting for 0.40 mmoles of the $\mathrm{CO}_{2}$ by formic acid oxidation (equation 4). As noted above giant palladium clusters are known (11) to catalyze the oxidation of formic acid. Insignificant amounts of $H_{2}$ and co are produced. Thus the ramaining $0.60-0.40=0.20$ moles of $\mathrm{CO}_{2}$ must arige from the reduction of the $\mathrm{PdCl}_{2}$ according to the following oquation: $\mathrm{PdCl}_{2}+\mathrm{HCO}_{2} \mathrm{H}-\ldots-\mathrm{Pd}+2 \mathrm{HCl}+\mathrm{CO}_{2}$

This equation is consistent with the ratio $\left[\mathrm{CO}_{2}{ }^{\mathrm{red}} / /(\mathrm{Pd})\right.$ ratio $0 \mathrm{f} 0.20 / 0.20=$ 1.

\section{(e) Silver (Flaure 51:}

silver nitrate rather than eilver chloride was used as a source of eilver in order to heve a more soluble derivative. Howerer, this introduces the poseible complication of the presence of nitrate, which can in principle serve as formic acid oxidant. However, nitrate eyeteme are of importance ince they approximate more closely DWPF procese conditions and in future work studien with the other motale will also be extended to nitrates.

silver nitrate corresponding to 0.88 moles of motal produced $3.15 \mathrm{mmolea}$ of 
$\mathrm{CO}_{2}$ with the consumption of 0.7 mmoles of $\mathrm{O}_{2}$. Thus $1.4 \mathrm{mmoles}^{\circ}$ the $\mathrm{CO}_{2}$ produced must arise from formic acid oxidation (equation 4). This leaves 3.15 $1.4=1.75$ mooles of $\mathrm{CO}_{2}$ to come from other sources. No $\mathrm{H}_{2}$ is observed indicating that formic acid decomposition (equation 1) cannot be a source of this extra $\mathrm{CO}_{2}$. Thus this "extra" $\mathrm{CO}_{2}$ must arise from reduction of the ilver nitrate. The equation

$$
\mathrm{AgNO}_{3}+2 \mathrm{HCO}_{2} \mathrm{H}-\ldots-\mathrm{Ag}+\mathrm{NO}+2 \mathrm{H}_{2} \mathrm{O}+2 \mathrm{CO}_{2}
$$

can account for the obeerved $\left(\mathrm{CO}_{2}{ }^{\mathrm{red}}\right) /(\mathrm{Ag})$ ratio of $1.75 / 0.88 \mathrm{~m} 2.0$. Alternatively, reduction of nitrate to $\mathrm{N}_{2} \mathrm{O}$ without reduction of the eilver could also account for the obeerved $\mathrm{CO}_{2}$ production. However, the presence of a gray precipitate in the mixture after completion of the reaction le consistent with reduction of the eilver nitrate to elemental oilver. Further experiments are planned in order to detect any nitrogen oxide producte and to establieh the nature and amount of the gray precipitate.

\section{(E) Osmium:}

Commercial oamium trichluride $(0.27$ moles $)$ appeared to be catalytically inactive under the experimental conditione used in this work. The initial reaction mixture was blue and it turned purple during the course of the heating.

\section{(a) Iridium (Figure 61:}

The behavior of hydrated iritium trichloride upon heating with formic acid was the most complicsted of any of the metals included in this investigation. Thus commercial hydrated iridium trichloride $\left(0.35\right.$ mmoles) produced 4.45 mmoles of $\mathrm{co}_{2}$ with the consumption of 1.87 mmoles of $O_{2}$ indieating that 3.74 mmoles of the $\mathrm{CO}_{2}$ produced arises from formic acid oxidation (eguation 4). During the course of this experiment (Figure 5) the oxidation proceeded to the extent that 94 of the original oxygen was consumed indicating the efficiency of leidium trichloride as a formic acid oxidation catalyot. The initial brown color of the reaction mixture faded to a very pale yellow during the course of the oxygen consumption. After moet of the oxygen was depleted, the color of the solution began to deepan and evolution of both $\mathrm{H}_{2}$ and $\mathrm{co}$ began. At the ond of the reaction the mixture was deep arange and 0.61 moles of $\mathrm{H}_{2}$ were obeerved indieating that 0.61 moles of the $\mathrm{CO}_{2}$ measured at the end of the experiment arove from formle actd decomposition (equation 1). Oxidation and decomposition accounted for eaventially all of the $\mathrm{CO}_{2}$ production within experimental error. $(3.74+0.61=4.35$ out of 4.45 mmoles): the amal amount of remaining $\mathrm{CO}_{2}$ (only 0.1 mole) might arise from reduction of come of the Ir(IV) in comericial "hydrated iridium trichloriden to 
Ir(III). The production of 0.77 mmoles of co indicates that iridium triehloride can dehydrate formic acid (equation 2) beyond the extent required to form the iridium carbonyl derivative obeerved by cleare and Griffith $(9,10)$. Iridium tri-. chloride appeare to be the mout catalytically active of the noble metals investigated, at least under these conditione (concentrated formic acid and chloride complexes) contrary to expectations before this project that 5d transition metals would be lese active catalytically than 4d transition motale in accord with the stronger metal-ligand bonde generally formed by sd traneition motale.

(i) Platinum (Figure 71:

A 0.1 mmole ample of commercial $\mathrm{K}_{2} \mathrm{PtCl}_{4}$ produced $2.52 \mathrm{mnoles}$ of $\mathrm{CO}_{2}$ with the consumption of 1.29 mmoles of $\mathrm{O}_{2}$. The colution was nearly colorless during this reaction. The $\left[\mathrm{CO}_{2}\right] /\left[\mathrm{O}_{2}\right]$ ratio of $2.52 / 1.29$. 1.95 indicates that all of the $\mathrm{CO}_{2}$ was produced by formic acid oxidation (oquation 4). The turnover number of $2.52 / 0.1$ - 25.2 indicates that platinum under these conditione has eignificant catalytic activity for formic acid oxidation. Only 0.2 mole of co was observed indicating that formic acid dehydration (equation 2 ) is a minor reaction under these conditions. The solid deposit on the walls of the reaction flask appeared to be Pt metal; complete reduction of the 0.1 mole of $K_{2}$ Ptcl 4 to Pt netal would produce only 0.1 mmole of $\mathrm{CO}_{2}$.

i) Gold:

An old deliquesced sample of hydrated chloroauric acid was used so that the amount of gold introduced into the system can be only crudely estimated as 0.2 mmoles. The absence of significant $\mathrm{O}_{2}$ consumption, $\mathrm{H}_{2}$ production, and co production indicates the absence of formic acid oxidation (equation 4), formic acid decomposition (equation 1), and formic acid dehydration (aquation 2 ), respectively. Thus 11 of the $\mathrm{CO}_{2}$ production must come from reduction of the Au(III) to motallic gold. Thle is consiotent with the precipitation of gold after the reaction is completed.

\section{Discunetion}

The most common procese ablerved in these experimente, run under aerobic conditione, was the oxidation of formic acid to $\mathrm{CO}_{2}$ (equation 4 ) which occurred in the experimente with Ru, Rh, $\mathrm{Pd}, \mathrm{Ag}, \mathrm{Ir}$, and $\mathrm{Pt}$. Only in the experiments with Os and Au was no evidence for formic acid oxidation observed. This observation suggeste that the oxidation process (equation 4) dominates over decomposition (equation 1) and dehydration (equation 2). Furthormore, the oxidation of formic 
acid (equation 4) is the oum of the formic acid decomposition to $\mathrm{CO}_{2}$ and $\mathrm{H}_{2}$ (equation 1) and the oxidation of $\mathrm{H}_{2}$ to $\mathrm{H}_{2} \mathrm{O}$ by the following equation:

$$
2 \mathrm{H}_{2}+\mathrm{O}_{2}-\ldots \rightarrow 2 \mathrm{H}_{2} \mathrm{O}
$$

since $\mathrm{H}_{2}$ oxidation (equation 7 ) is highly exothermic, formic acid oxidation is favored thermodynamically over formic acid decomponition when both oxygen and a catalytically active metal are present. The ability of many noble metale to catalyze the oxidation of $\mathrm{H}_{2}$ to $\mathrm{H}_{2} \mathrm{O}$ may account for our oblervation of $\mathrm{H}_{2}$ production in only a limited number of cases in these aeroble experimente. We are initiating some experiments under anaerobic conditions in order to suppress oxidation reactions (equations 4 and 7 ) in order to obtain more information on decomposition and dehydration reactione which may be unable to compete with oxidation reactions. If formic acid oxidation (equation 4) is a sum of formic acid decomposition (equation 1) and hydrogen oxidation (equation 7), then metale catalyzing formic acid oxidation under aeroble conditione will catalyze formic acid decomposition under anaerobic conditions. If this is the case, then hydrogen production from formic acid decomposition during the treatment of nuclear wastes might be reduced by running the formic acid treatment in the presence of alr. Under euch aerobic conditions $\mathrm{H}_{2}$ will be smoothly oxidized catalytically to innocuous $\mathrm{H}_{2} \mathrm{O}$ by the noble metale before it can be evolved to caur an explosion hazard in the proceseing

By comparison with formic acid oxidation to $\mathrm{CO}_{2}$ formic acid decomposition to $\mathrm{CO}_{2}$ and $\mathrm{H}_{2}$ was only infrequently observed in these aeroble experiments. Major amounte of $\mathrm{H}_{2}$ under aerobic conditione were only obeerved in the case of Ir although minor amounte of $\mathrm{H}_{2}$ were also observed in the Ru experimente. Formic acid dehydration to co (equation 2) was only obeerved in ignificant guantities in the If experiment.

The experiment with AgNo 3 is interest eince nitrate is present in large quantities in the nuclear waste procesed with formic acid in the DWPF plant. The stoichiometry of the production of $\mathrm{CO}_{2}$ relative to $\mathrm{AgNO}_{3}$ coupled with the lack of $\mathrm{H}_{2}$ pror uction and $\mathrm{O}_{2}$ dopletion suggeets that concentrated formic acid can reduce nitrate to No. Thle obearvation may be particularly elgniflcant whon extended to Ru, since Ru form a variety of stable nitrouyl dorivatives (19) which might well have different catalytic activity than Ru in the aboence of No 11 gands. Experiments with all of the metals Included in this etudy in the presence of excese nitrate relative to motal are planned in the near future in order to asese the role of nitrate and No ligande produced by nitrate reduction in their catalytic 
activity for formic acid reactiona.

\section{Literature Referencen}

(1) G. R. Choppin and J. Rydberg, "Nuclear Chemietry: Theory and Applications," Pergamon, Oxford, 1980, p. 505.

(2) R. M. Laine, R. G. Rinker, and P. C. Ford, I. Ame Cheme sore, 99,252 (1977).

(3) S. H. Strause, K. H. Wittmire, and D. F. Shrivar, J. Oraanometal. chem., 174, C59 (1979).

(4) R. Colton and J. E. Knapp, Aunt. J. Cheme, 25, 9 (1972).

(5) R. Colton and R. H. Farthing, Aurt, J. Chem., 20, 1283 (1967).

(6) R. Colton and R. H. Farthing, Aurt. J. Cheme, 22, 2011 (1969).

(7) R. Colton and R. H. Farthing, Augt. J.Cheme, 24, 903 (1971).

(8) M. J. Cleare and W. P. Giffith, Jechem. Soc, A. 372 (1969).

(9) M. J. Cleare and W. P. Geiffith, I. Chem, Soc. A, 2788 (1970).

(10) R. Colton, R. H. Farthing, and J. E. Knapp, Aunt. J. Cheme, 23, 1351 (1970).

(11) N. M. zhavoronkoy, Ya. A. Pazderaky, M. R. Starcheveky, P. I. Pasychik, M. N. Vargaftik, and I. I. Moiseov, 2, Anorg. Mllon, Cheme, 576, 284 (1989).

[12] E. B. Boyar and S. D. Robinson, Coord. Chem, Reve., 50, 109-208 (1983).

(13) T. R. Eelthouse, Prog. Inerg, Chnn, 29, 73-166 (1982).

(14) P. P. Pruchnj :, Pure Apole Cheme, 61, 795 (1989).

(15) T. A. Stephenwon and G. Wikincon, J. Inorg. Nucle Chme, 28, 2285 (1966).

[16] A. Bino, F. A. Cotton, and T. R. Felthouse, Inorg. chem., 18, 2599 (2979).

(17) A. J. Lindsay, G. MLlkineon, M. Motevalli, and K. B. Hurathouse, J, Cham. Soc, Dalton, 2723 (1987).

(18) H. Lohmann, and G. Wilkinson, Jecheme Soc.e Delton, 191 (1981).

(19) E. A. Seddon and K. R. Seddon, "The Chemistry of Ruthenium," Elsevier, Amsterdam, 1984, PP.1105-1162. 
TABLE 1

THE NOBLE METALS USED IN THIS STUDY

\begin{tabular}{|c|c|c|c|c|c|}
\hline Metal & $\begin{array}{c}\text { Valence } \\
\text { Electrons }\end{array}$ & $\begin{array}{l}\text { Fission } \\
\text { Yield }^{a}\end{array}$ & $\begin{array}{c}\text { Compciund } \\
\text { Used }\end{array}$ & $\begin{array}{l}\text { Quantity } \\
\text { Used. mmol }\end{array}$ & Eiqure \\
\hline \multicolumn{6}{|c|}{ 4d Transition Metals } \\
\hline Ruthenium & 8 & 2.15 & $\mathrm{RuCl}_{3} \cdot \times \mathrm{H}_{2} \mathrm{O}^{\mathrm{b}}$ & 0.9 & 2 \\
\hline Rhodium & 9 & 0.39 & $\mathrm{RhCl}_{3} \cdot 3 \mathrm{H}_{2} \mathrm{O}$ & 0.12 & 3 \\
\hline Palladidm & 10 & 1.16 & $\mathrm{PdCl}_{2}$ & 0.20 & 4 \\
\hline silver & 11 & 0.06 & $\mathrm{AgNO}_{3}$ & 0.88 & 5 \\
\hline
\end{tabular}

\section{5d Transition Metals}

osmium

Iridium

Platinum

Gold

8

3

10

11

0
0
0
0
$\mathrm{OsCl}_{3}$
$\mathrm{IrCl}_{3} \cdot 3 \mathrm{H}_{2} \mathrm{O}$
$\mathrm{K}_{2}$ PtCl $_{4}$

$\mathrm{HAUCl}_{4} \cdot \mathrm{xH}_{2} \mathrm{O}$
0.27

0.35

0.1

6

7

(a) These fiselion yields are quoted in kilograms produced from 1 ton of spent uranium fual originally enriched to 3.36 in $235 \mathrm{~V}$ after $33,000 \mathrm{wWd} / \mathrm{t}$ uranium burn-up at a flux of $3 \times 10^{13} \mathrm{n} \mathrm{ca} \mathrm{cm}^{-1}$ at a cooling time of 10 years.

(b) These noble motal chloride samples were about 15 years old and had deliquesced on standing becoming liquid. Therefore the amount of motal introduced into the experiment was estimated only very crudely. 
Figure 1: Decomposition of 88 formie acid at its boiling point in the abaence of addad noble matale.

Figure 2: Decomposition of 88 formic acid in the presence of hydrated ruthonium trichloride (ca. 0.9 moles Ru).

Figure 3: Decomposition of 88 formic acid in the presence of hydrated rhodium trichloride $(0.12 \mathrm{mmoles} \mathrm{Rh})$.

Figure 4: Decomposition of 88 formic acid in the presence of palladium chloride (0.20 mmoles Pd).

Figure 5: Decomposition of 88 tormie acid in the presence of eslver nitrate $(0.88$ mmoles $\mathrm{Ag})$.

Figure 6: Decomposition of 88 formic acid in the preaence of hydrated 1ridium trichloride $(0.35$ moles Ir).

Figure 7: Decomposition of 888 formic acid in the presence of $\mathrm{R}_{2} \mathrm{PtCl} 4 \mathrm{lO.1}$ mnoles $\mathrm{Pt}$ ). 
Formic Acid

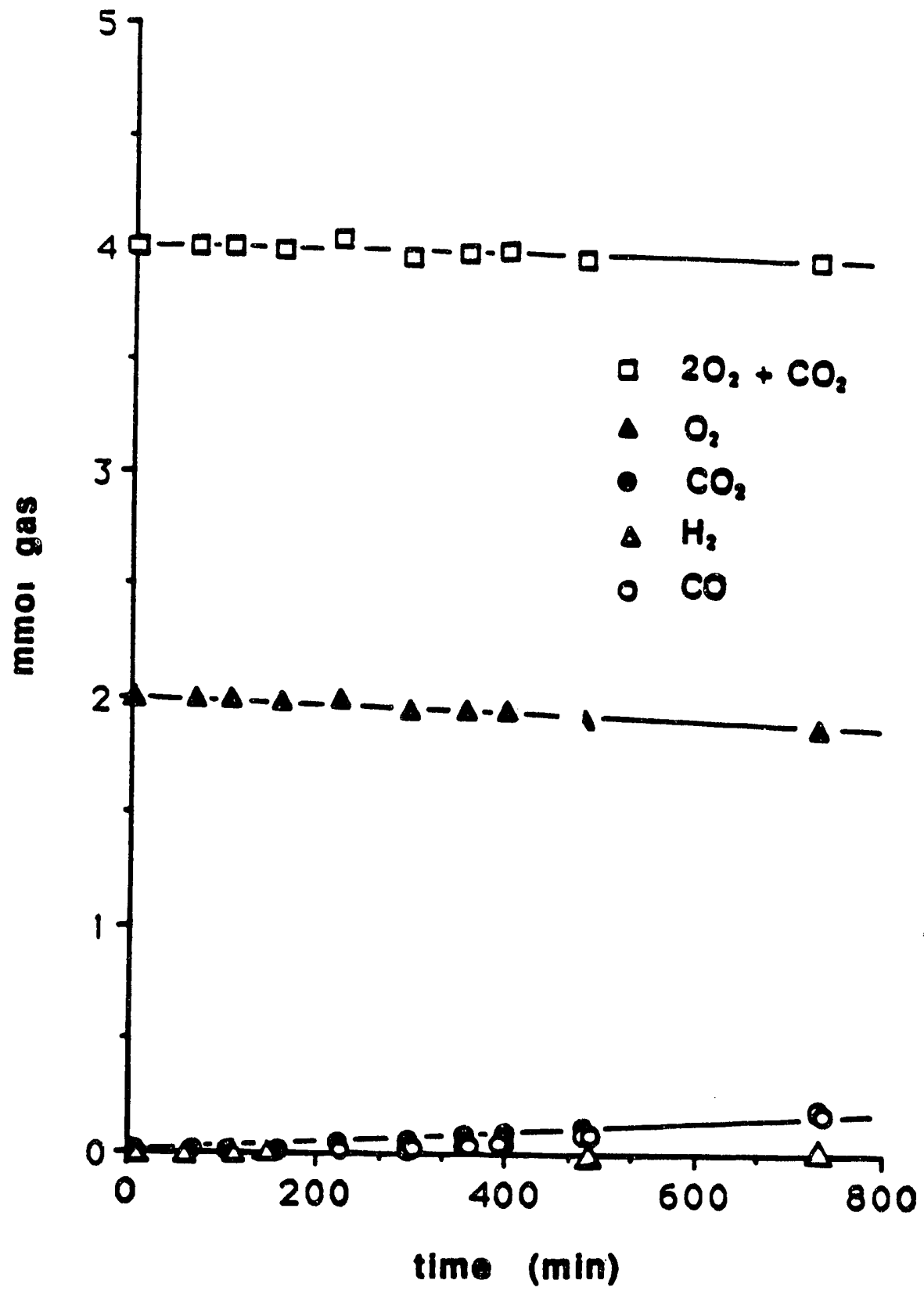


$\mathrm{RuCl}_{3}+$ Formic Acld

(approx. $0.89 \mathrm{mmol}$ )

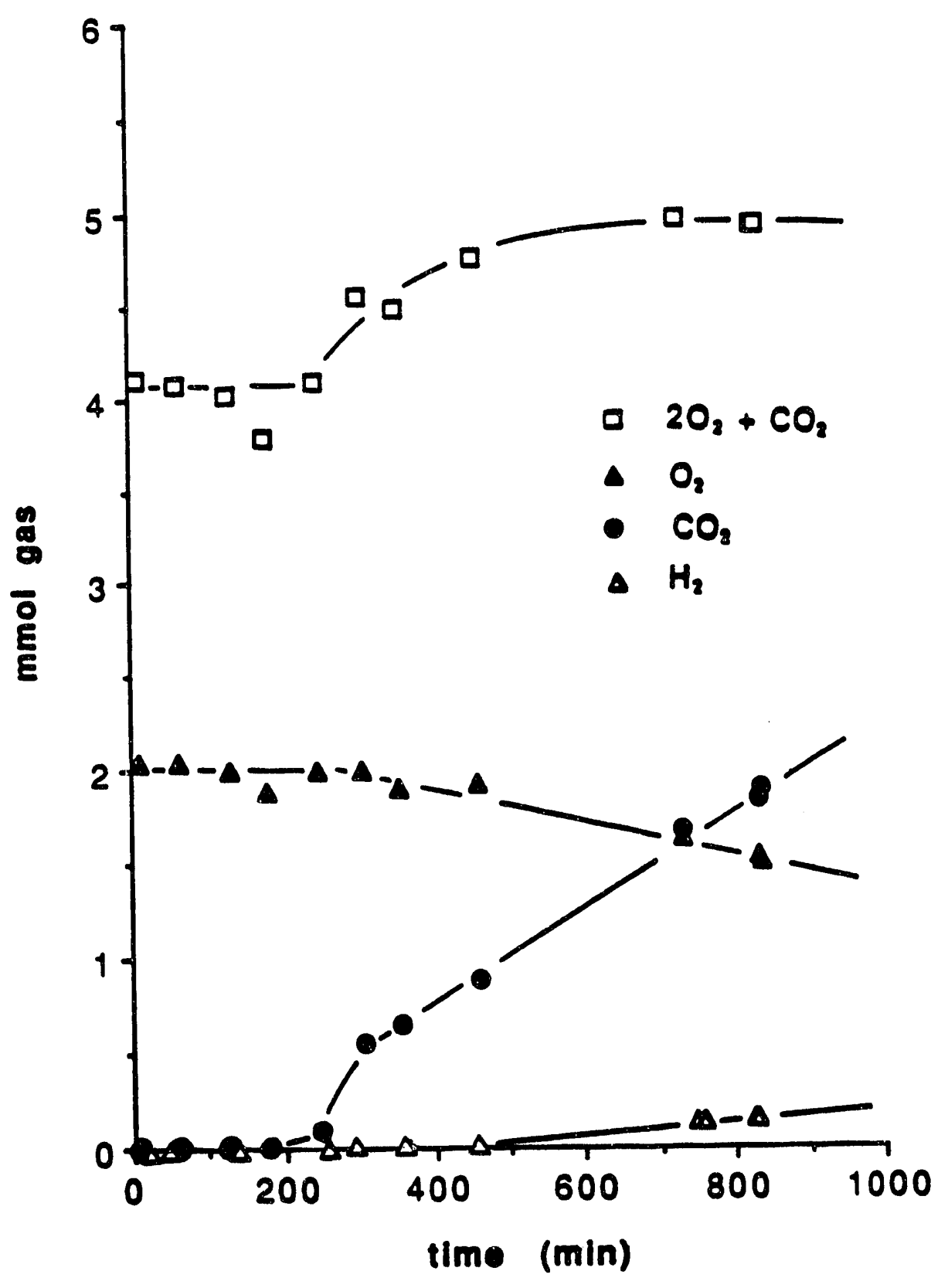


$\mathrm{RhCl}_{3}+$ Formlc Acld (0.12 $\mathrm{mmol}$ )

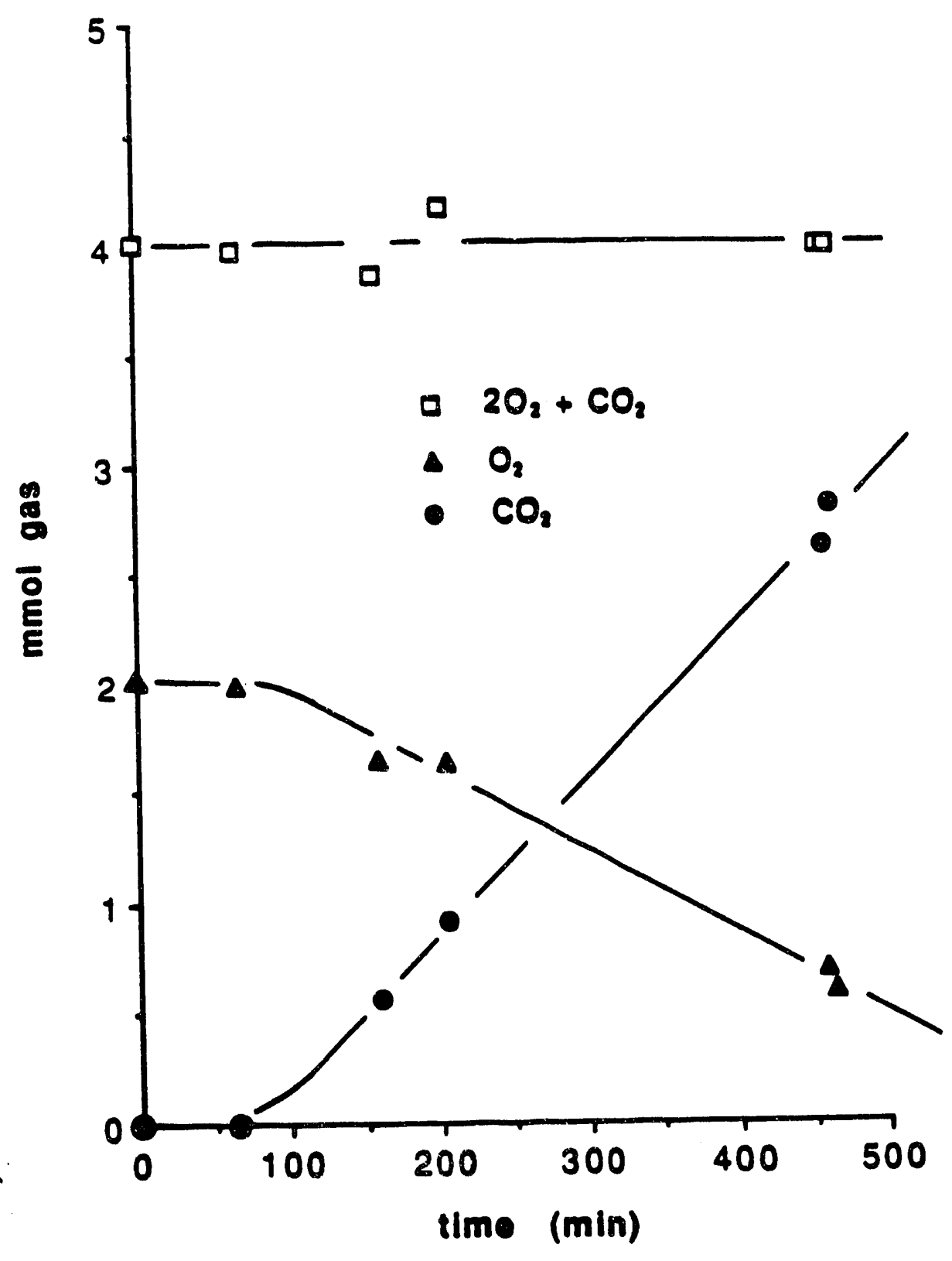




\title{
$\mathrm{PdCl}_{2}+$ Formic Acid $\left.0.20 \mathrm{mmol} \mathrm{Pd}\right)$
}

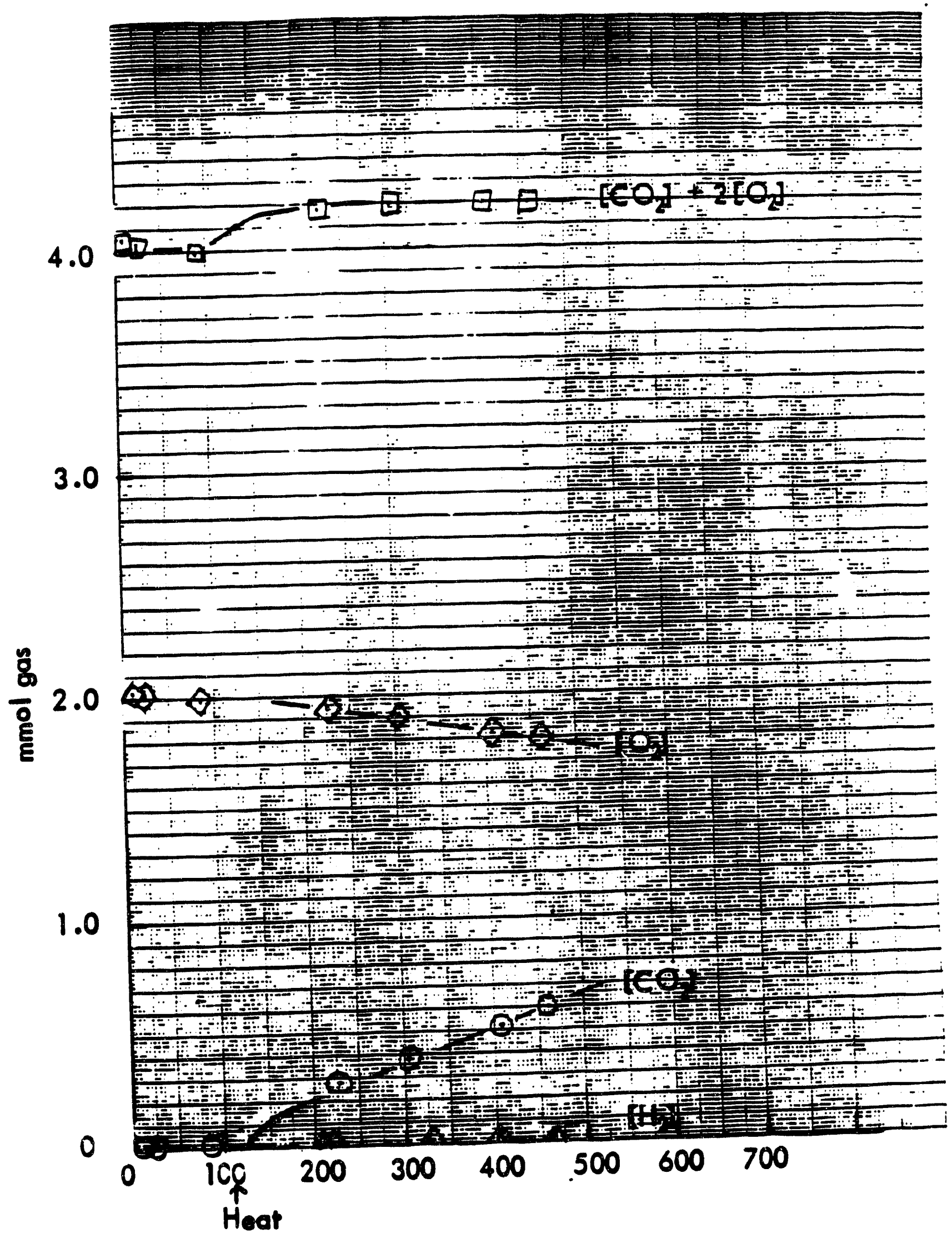

\author{
Time (minutes)
}


$\mathrm{AgNO}_{3}+$ Formic Acld (0.88 $\mathrm{mmol}$ )

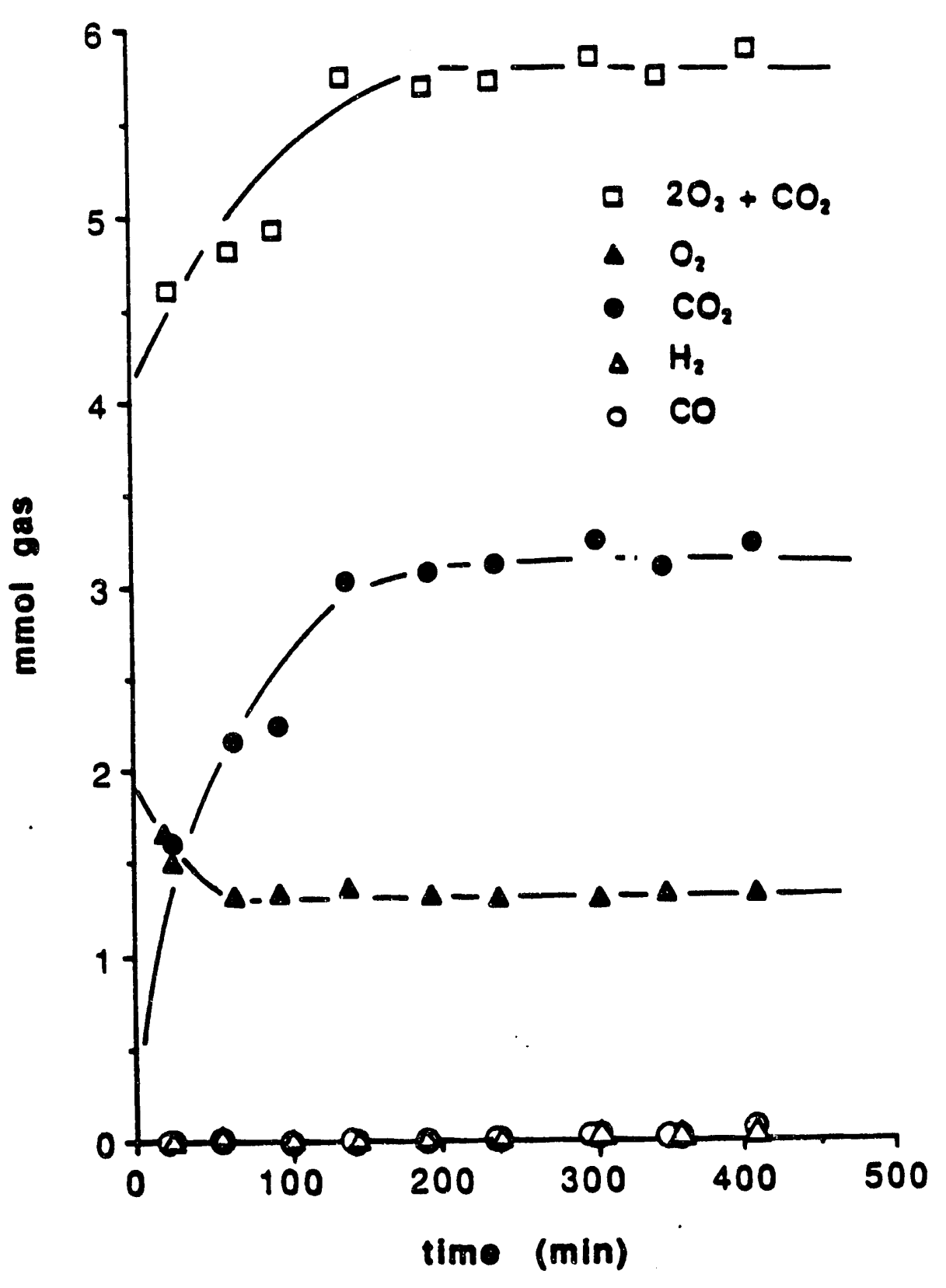


$\mathrm{IrCl}_{3}+$ Formlc Acld

(0.35 mmol)

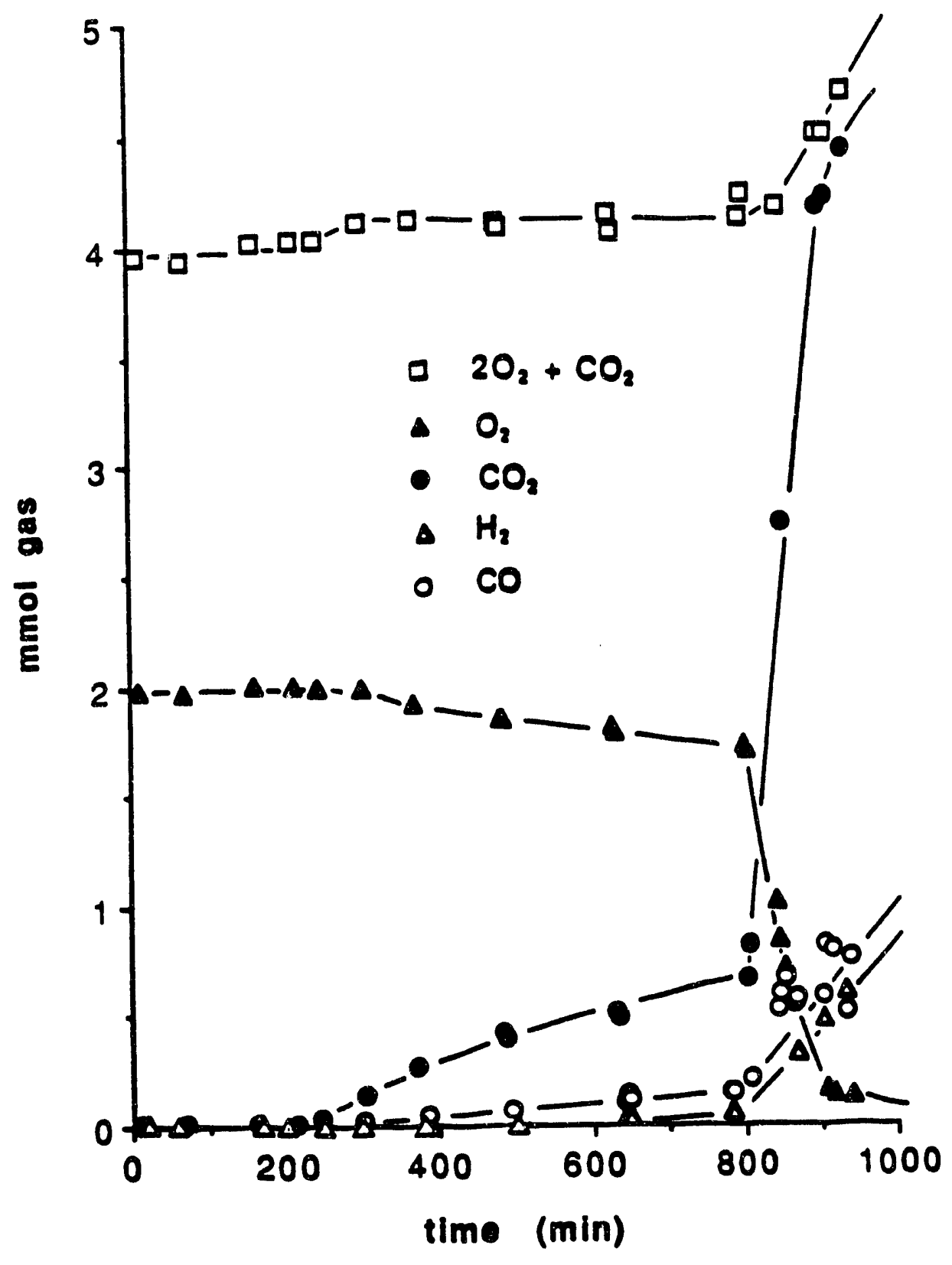


$\mathrm{K}_{2} \mathrm{PtCl}_{4}+$ Formic Acld

(0.10 mmol)

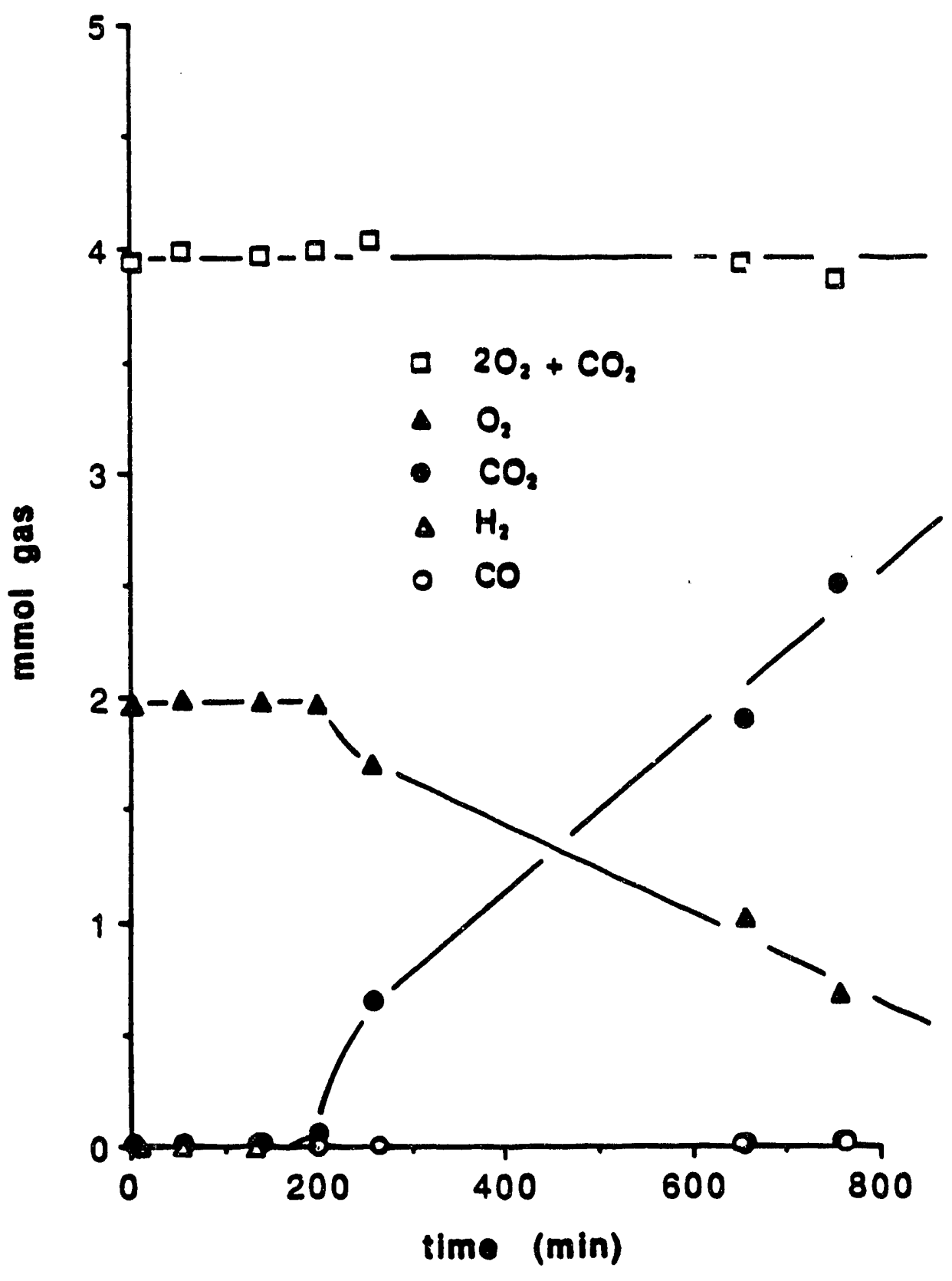




\section{TECHNICAL REPORT}

to the

Westinghouse Savannah River Laboratory

Aiken, South Carolina

on

\section{ELUCIDATION OF NOBLE METAL/FORMIC} ACID CHEMISTRY DURING DWPF FEED PREPARATION

by

R. B. King, Regents' Professor and Principal Investigator

A. D. King, Jr., Professor and Faculty Associate

N. K. Bhattacharyya, Post-Doctoral Fellow

Y.-H. Lim, Graduate Student

Report 2

April, 1991 
Studies of the Reaction of NaNO/3 with Formic Acid Under an Argon Blanket

Treatment of 2 mmoles of $\mathrm{NaNO}_{3}$ with $\mathbf{4 0} \mathrm{ml}$ of formic acid resulted in the evolution of $8.5 \mathrm{mmol}$ of $\mathrm{CO}_{2} 1.5 \mathrm{mmol}$ of $\mathrm{N}_{2} \mathrm{O}, 2.7 \mathrm{mmol}$ of $\mathrm{N}_{2}$, and $0.4 \mathrm{mmol}$ of $\mathrm{CO}$ at the end of the experiment. The production of $1.5 \mathrm{mmol}$ of $\mathrm{N}_{2} \mathrm{O}$ and $2.7 \mathrm{mmol}$ of $\mathrm{N}_{2}$ would require the presence of at least $8.4 \mathrm{mmol}^{\circ} \mathrm{NO}_{3}{ }^{-}$in the system and would produce $19.5 \mathrm{mmol}$ of $\mathrm{CO}_{2}$ whereas actually a maximum of $2 \mathrm{mmol}$ of $\mathrm{NO}_{3}$-could be consumed and the production of only $8.5 \mathrm{mmol}$ of $\mathrm{CO}_{2}$ was observed. This discrepancy lead to a detailed investigation of possible sources of error in the experimental methods.

In this experiment the amounts of gases were calculated by comparing the peak heights with that of argon taken as an internal standard. So if some gas leaked out from the system at a time prior to completion of the reaction, the depleted argon would yield an inflated value for the calculated number of mmoles of the product gases. Other possible sources of an increase in the apparent $\mathrm{N}_{2}$ production towards the end of the reaction could be due to:

(1) Air leaking into the system;

(2) Production of som other oxide of nitrogen which has the same retention time as $\mathrm{N}_{2}$. The possibility of misuken identity (2) can be checked by producing $\mathrm{NO}$ and $\mathrm{NO}_{2}$ by authentic synthetir nethods and determining their retention times under the same conditions of the experim .tt. These two gases are the only other gaseous products possible from the reduction of $\mathrm{NO}_{3}{ }^{-}$. Thus the next logical step was to produce some $\mathrm{NO}$ and $\mathrm{NO}_{2}$ and to try to determine their behavior in our gas chromatography system.

The reaction of $8 \mathrm{M} \mathrm{HNO}_{3}$ with copper wire under an argon blanket was used to generate NO. The ensuing gas, when introduced into the gas chromatograph showed a strong peak with a retention time of $\sim 3.5$ mins. The retention time of $\mathrm{N}_{2}$ is $\sim 2.6$ mins. and therefore the peak identified as $\mathrm{N}_{2}$ cannot be attributed to NO. When $\mathrm{O}_{2}$ was deliberately injected into the $\mathrm{HNO}_{3} / \mathrm{Cu}$ reaction flask, a yellow-brown gas was produced which presumably was $\mathrm{NO}_{2} / \mathrm{N}_{2} \mathrm{O}_{4}$. When the headgas from the flask was injected into the gas chromatograph, the $3.5 \mathrm{~min}$. peak was no longer observed, but no new peak assignable to $\mathrm{NO}_{2} \mathrm{~N}_{2} \mathrm{O}_{4}$ was found. Interestingly, the gas mixture in the flask became colorless within a minute apparently due to dissolution of $\mathrm{N}_{2} / \mathrm{N}_{2} \mathrm{O}_{4}$ in water (see equation 2 below). To ascertain the behavior of $\mathrm{NO}_{2} \mathrm{~N}_{2} \mathrm{O}_{4}$ on the gas chromatography columns, pure $\mathrm{NO}_{2}$ was generated by the reaction of concentrated $\mathrm{HNO}_{3}$ on copper and was injected into the gas chromatograph. Again no peak assignable to $\mathrm{NO}_{2} / \mathrm{N}_{2} \mathrm{O}_{4}$ was observed. We suggest that 
the failure to observe a peak assignable to $\mathrm{NO}_{2} / \mathrm{N}_{2} \mathrm{O}_{4}$ arises from establishment of the equilibrium $2 \mathrm{NO}_{2}=\mathrm{N}_{2} \mathrm{O}_{4}$ during the passage of the gas through the gas chromatography column. Generation of $\mathrm{NO}_{2}$ from this equilibrium mixture as it passes through the column would merely broaden the baseline of the chromatogram instead of leading to a sharp $\mathrm{NO}_{2}$ peak.

According to the literature, the reaction of $\mathrm{N}_{3}$. with formic acid produces $\mathrm{NO}$, but no peak assignable to NO was observed on the shromatogram. If there was an air leak into the system, the absence of NO could possibly be explained by the following sequence of reactions:

$$
\begin{aligned}
& 2 \mathrm{NO}(\mathrm{g})+\mathrm{O}_{2}(\mathrm{~g}) \text { [from air] } \longrightarrow 2 \mathrm{NO}_{3}(\mathrm{~g}) \\
& \mathrm{NO}_{2}(\mathrm{~g})+\mathrm{H}_{2} \mathrm{O}(\mathrm{l}) \longrightarrow 2 \mathrm{HNO}_{3}+\mathrm{NO}(\mathrm{g})
\end{aligned}
$$

leading to the overall reaction

$$
4 \mathrm{NO}(\mathrm{g})+3 \mathrm{O}_{2}(\mathrm{~g})+2 \mathrm{H}_{2} \mathrm{O}(\mathrm{l}) \longrightarrow 4 \mathrm{HNO}_{3}(\mathrm{l})
$$

It is apparent from the overall reaction that a leakage of air (an $\mathrm{O}_{2} / \mathrm{N}_{2}$ mixture) could result in an increase of the $\mathrm{N}_{2}$ concentration in the product gas mixture with no concurrent increase in the $\mathrm{O}_{2}$ concentration. It is interesting to note in this regard that the addition of $\mathrm{O}_{2}$ to $\mathrm{NO}$ intended to produce $\mathrm{NO}_{2}$, in fath, created a strong vacuum just as predicted by reaction (3), which consumes gaseous $\mathrm{NO}$ and $\mathrm{O}_{2}$ leading to liquid aqueous $\mathrm{HNO}_{3}$.

\section{Studies on the reaction of $\mathrm{NaNO}_{2}$ with Formic Acid under an Argon Blanket}

The gases observed in this reaction are $\mathrm{CO}_{2}, \mathrm{~N}_{2} \mathrm{O}$, but no $\mathrm{CO}$. The absence of the $\mathrm{NO}_{2}$ peak confirms the observation outlined above that an $\mathrm{NO}_{2}$ peak cannot be observed under these experimental conditions.

In addition, it is interesting to note that at low temperatures the reduction of $\mathrm{NaNO}_{2}$ with formic acid proceeded more slowly than the corresponding reduction of $\mathrm{NaNO}_{3}$.

\section{Experiments with IDMS (pH $=11.0$ ) Sludge}

(a) $3.5 \mathrm{~g}$. of the sludge was added to $40 \mathrm{ml}$. of chilled formic acid. The mixture was flushed with argon while the temperature was maintained at $0^{\circ} \mathrm{C}$. The gases observed by gas chromatography were $\mathrm{CO}_{2}$ and $\mathrm{N}_{2} \mathrm{O}$ and a small amount of $\mathrm{CO}$ after heating. $\mathrm{No}_{2}$ was observed. The solution remaining at the end of the experimeni was strongly acidic (negative $\mathrm{pH}$ recorded by the $\mathrm{pH}$ meter).

(b) In this experiment $30 \mathrm{ml}$. of sludge and $10 \mathrm{ml}$. of formic acid was used under the same experimental conditions as above. In addition to the gases observed above in (a) a significant amount of $\mathrm{NO}$ was observed. However, the production of $\mathrm{H}_{2}$ was negligible. 
(c) Under the same experimental conditions $30 \mathrm{ml}$. of sludge, $10 \mathrm{ml}$. of formic acid, and $0.3 \mathrm{~g}$. of hydrated ruthenium chloride were used. In this experiment $\mathrm{CO}_{2}$ and $\mathrm{N}_{2} \mathrm{O}$ were observed but no NO. Some $C U$ was observed after prolonged heating of the reaction mixture. The production of $\mathrm{H}_{2}$ again was negligible ( $<0.02$ mmole). 


\title{
TECHNICAL REPORT
}

to the

Westinghouse Savannah River Laboratory

Aiken, South Carolina

\section{ELUCIDATION OF NOB ACID CHEMISTRY DURING DWPF FEED PREPARATION}

by

R. B. King, Regents' Professor and Principal Investigator

A. D. King, Jr., Professor and Faculty Associate

N. K. Bhattacharyya, Post-Doctoral Fellow

Y.-H. Lim, Graduate Student

Report 3

May, 1991

Revised July, 1991

\begin{abstract}
The effect of the noble metals Ru, Rh, and Pd, added as chlorides, on the decomposition of formic acid in the presence of IDMS $(\mathrm{pH}=11.0)$ sludge has been in the experiments $\mathrm{H}_{2}$ gas is produced in the experiments with $\mathrm{Rh}$, some $\mathrm{H}_{2}$ is produced in the experiments with $\mathrm{Pd}$, but no $\mathrm{H}_{2}$ is produced in the experiments with $\mathrm{Ru}$. The $\mathrm{H}_{2}$ evolution with $\mathrm{Rh}$ in the sludge is not inhibited by the addition of equimolar amounts of stannous chloride. Contml experiments show that treatment of pure formic acid with $R h$ does not give $\mathrm{H}_{2}$ indicating that one or more components in the sludge are essential for the catalytic activity of the Rh. Further experiments are planned in order to identify the component or components in the sludge that are essential for the catalytic activity of the Rh.
\end{abstract}

Addendum (July, 1991). The composition of the IDMS $(\mathrm{pH}=11.0)$ sludge used in this work is given in Table 1A. 
Table 1A

Composition of the IDMS (pH 11.0) HM Sludge Simulant Used in this Work

Amount, $\%$ by weight

\begin{tabular}{|c|c|}
\hline $\mathrm{Al}(\mathrm{OH})_{3}$ & 25.031 \\
\hline $\mathrm{BaSO}_{4}$ & 0.219 \\
\hline $\mathrm{Ca}_{3}\left(\mathrm{PO}_{4}\right)_{2}$ & 0.097 \\
\hline $\mathrm{CaCO}_{3}$ & 1.478 \\
\hline $\mathrm{CaSO}_{4}$ & 0.000 \\
\hline $\mathrm{Cr}_{2} \mathrm{O}_{3}$ & 0.220 \\
\hline $\mathrm{CsNO}_{3}$ & 0.028 \\
\hline $\mathrm{CuO}$ & 0.054 \\
\hline $\mathrm{Fe}(\mathrm{OH})_{3}$ & 25.893 \\
\hline $\mathrm{Nd}_{2} \mathrm{O}_{3}$ & 2.342 \\
\hline KOH & 0.170 \\
\hline MgO & 0.342 \\
\hline $\mathrm{MnO}_{2}$ & 6.650 \\
\hline $\mathrm{Na}_{2} \mathrm{CO}_{3}$ & 0.107 \\
\hline $\mathrm{Na}_{2} \mathrm{SO}_{4}$ & 0.471 \\
\hline $\mathrm{Na}_{3} \mathrm{PO}_{4}$ & 0.041 \\
\hline $\mathrm{NaCl}$ & 0.476 \\
\hline $\mathrm{NaF}$ & 0.259 \\
\hline $\mathrm{NaI}$ & 0.000 \\
\hline $\mathrm{NaNO}_{2}$ & 12.083 \\
\hline $\mathrm{NaNO}_{3}$ & 0.478 \\
\hline $\mathrm{NaOH}$ & 1.367 \\
\hline $\mathrm{Ni}(\mathrm{OH})_{2}$ & 1.308 \\
\hline $\mathrm{PbSO}_{4}$ & 0.220 \\
\hline $\mathrm{SeO}_{2}$ & 0.002 \\
\hline $\mathrm{SiO}_{2}$ & 5.039 \\
\hline $\mathrm{SrCO}_{3}$ & 0.408 \\
\hline $\mathrm{TeO}_{2}$ & 0.028 \\
\hline Zeolites & 9.342 \\
\hline $\mathrm{ZnO}$ & 0.043 \\
\hline $\mathrm{ZrO}_{2}$ & 1.842 \\
\hline
\end{tabular}




\section{Introduction}

This report describes the initial experiments performed to scout the effect of the noble metals found in fission products ( $\mathrm{Ru}, \mathrm{Rh}$, and $\mathrm{Pd}$ ) on the decomposition of formic acid upon treatment with a sludge simulant under conditions resembling actual process conditions. These experiments represent an initial phase in efforts to find a practical inhibitor for this unwanted $\mathrm{H}_{2}$ generation which can be used under actual process conditions.

\section{Experimental Methods}

Sludge ( $30 \mathrm{ml}$ ) and $10 \mathrm{ml}$ of $88 \%$ formic acid were placed in a $250 \mathrm{ml}$ one-neck reaction flask. An adapter consisting of a $T$-joint connected to a rubber septum and a rubber bulb was attached to the flask. The flask was placed in an ice bath and the contents were flused with argon for approximately 15 minutes. In some experiments a weighed quantity of the metal compound was added. Samples of the gas phase were analyzed at various intervals as the solution was heated.

\section{Results}

A. Blank run with IDMS (pH 11.0) sludge and formic acid in the absence of metals: As a control experiment IDMS sludge and formic acid were mixed and heated under an argon blanket and $\mathrm{CO}_{2}, \mathrm{~N}_{2} \mathrm{O}$, and $\mathrm{NO}$ was observed but no significant amount of $\mathrm{H}_{2}$ was produced.

B. Sludge with $\mathrm{RuCl}_{3}$ : Sludge $(30 \mathrm{ml}$.), $10 \mathrm{ml}$. of formic acid, and $0.3 \mathrm{~g}$. of hydrated ruthenium trichloride were used. $\mathrm{CO}_{2}$ and $\mathrm{N}_{2} \mathrm{O}$ were observed but no NO. Some $\mathrm{CO}$ was observed after prolonged heating. The production of $\mathrm{H}_{2}$ was negligible.

C. Sludge with $\mathrm{PdCl}_{2}$ : Three experiments were done with different amounts of palladiurn chloride (Table 1). Under an argon atmosphere a large amount of $\mathrm{CO}_{2}$ was produced. In addition, a small amount of $\mathrm{H}_{2}$ and other gases were produced. The large amount of gas evolved created a very high pressure inside the system causing a leak. Thus the absolute amount of the gases produced could not be determined but the volume composition of the product gases in the flask at three different elapsed times are given in Table 1. 
D. Sludge with $\mathrm{RhCl}_{3}$ : Sludge $(30 \mathrm{ml}), 10 \mathrm{ml}$. of formic acid, and $51 \mathrm{mg} .(0.2$ mmoles) of hydrated thodium trichloride were used. As in the case of palladium dichloride the large gas evolution caused a leak and the result can only be reported as volume percent at varying times. Very large amounts of $\mathrm{CO}$ and $\mathrm{H}_{2}$ were produced with smaller amounts of $\mathrm{N}_{2} \mathrm{O}$ and NO. Volume percent of the product gases in the flask at three different time intervals are given in Table 2 . The very large surge of $\mathrm{H}_{2}$ was observed in the temperature range 78 to $83^{\circ} \mathrm{C}$.

In contrast when $\mathrm{RhCl}_{3}$ was allowed to react with formic acid under anaerobic conditions, no significant amount of $\mathrm{H}_{2}$ was produced (Figure 1). Under aerobic conditions oxidation of formic acid was the primary reaction and no significant amount of $\mathrm{H}_{2}$ was produced (Figure 2).

To confirm the production of a large amount of gas in this experiment, an apparatus consisting of a thin rubber latex membrane was used. Although ballooning of the membrane confirmed the production of a significant amount of gas, their absolute amounts could not be calculated because $\mathrm{CO}_{2}$ permeated through the membrane. We plan to explore possible ways of modifying this experiment in order to avoid this difficulty.

These experiments indicate that some of the components in the IDMS sludge are essential for the catalytic activity of rhodium trichloride in the decomposition of formic acid to give $\mathrm{H}_{2}$.

E. Sludge with $\mathrm{RhCl}_{3}$ and $\mathrm{SnCl}_{2}$ : This experiment is the first of a series of experiments in order to find a poison for the noble-metal catalyzed decomposition of formic acid to give $\mathrm{H}_{2}$. Tin(II) chloride was chosen as the initial candidate for investigation because of the known tendency of tin(II) derivatives to complex with transition metals thereby blocking catalytic sites. In addition $\mathrm{SnO}$ and $\mathrm{SnO}_{2}$ arising from the tin compounds should be compatible with the waste vitrification process. The experiment with hydrated thodium trichloride ( 1 mmole) and the sludge was conducted as above but with the addition of an equimolar amount of added stannous chloride. In this experiment the added stannous chloride was found to have no effect on the production of $\mathrm{H}_{2}$ gas. Thus sittr an interval of 483-490 minutes, the reaction flask contained $50.5 \%$ of $\mathrm{CO}_{2}$ and $36.7 \%$ of $1 \mathrm{H}_{2}$ by volume.

\section{Tentative Conclusions}

The remarkable enhancement in catalytic activity of rhodium trichlorids; observed when IDMS $(\mathrm{pH}=11.0)$ sludge is present may be the result of several factors, all of which will be examined in the near future. First, the enhanced activity may reflect the existence of a heterogeneous catalyst system since the sludge is not completely dissolved under the 
conditions of the experiment. Second, the enhancement may be traceable to the somewhat elevated $\mathrm{pH}$ of the sludge/formic acid system, measured after heating to be 2.2, compared to the negative $\mathrm{pH}$ of pure formic acid. 
Figure 1: Reaction of formic acid with $0.19 \mathrm{mmol}$ hydrated rhodium trichloride under anerobic conditions. Note that insignificant $\mathrm{H} 2$ is produced.

Figure 2: Reaction of formic acid with $0.12 \mathrm{mmol}$ hydrated rhodium trichloride under aerobic conditions. Note the oxidation of formic acid to $\mathrm{CO}_{2}$ 
-

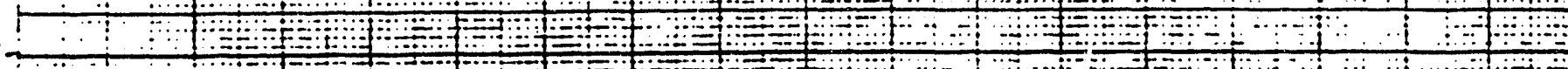
HOP

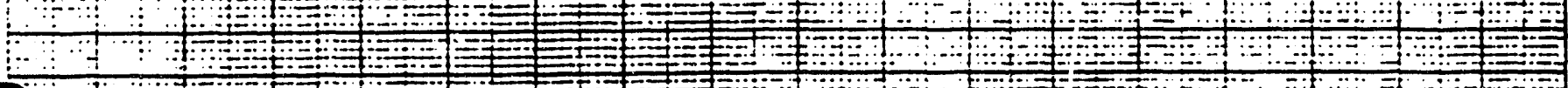

(a)

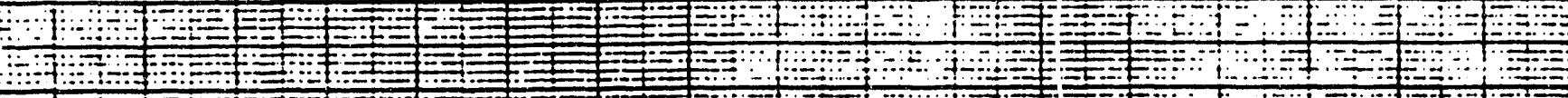

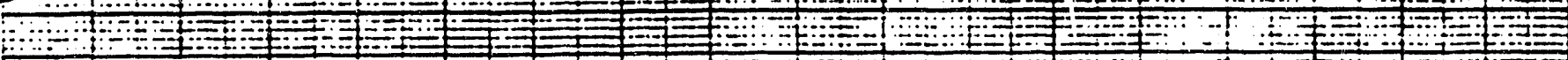

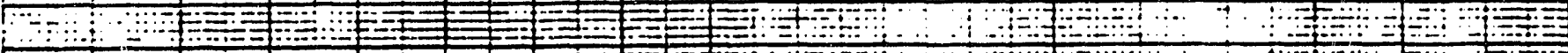

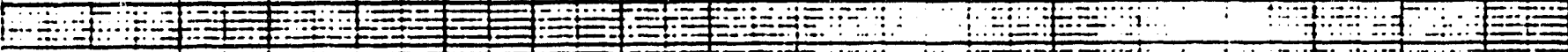
.

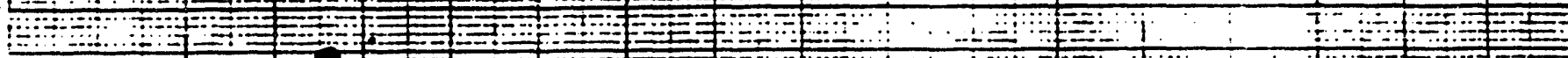
-

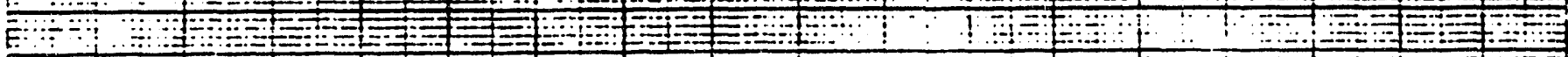

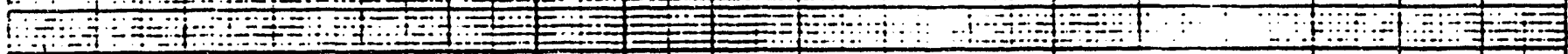

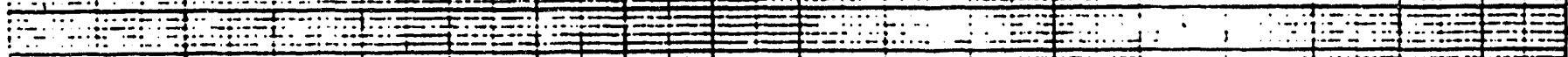

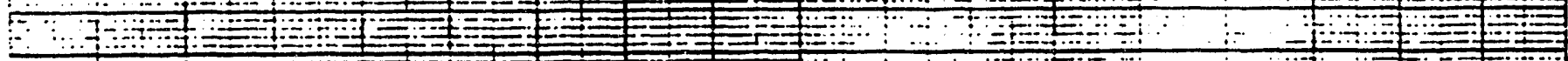
a.

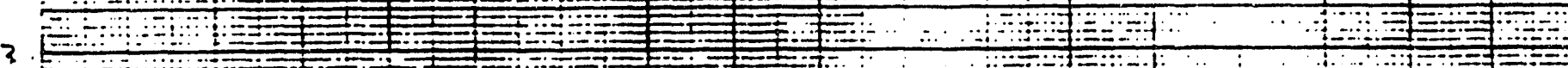

$3.5=3$

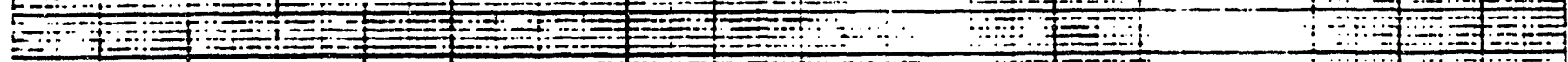
I 物 ${ }^{2} \mid$

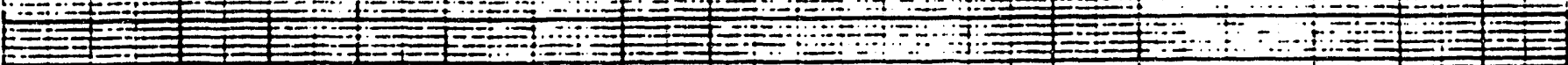
I

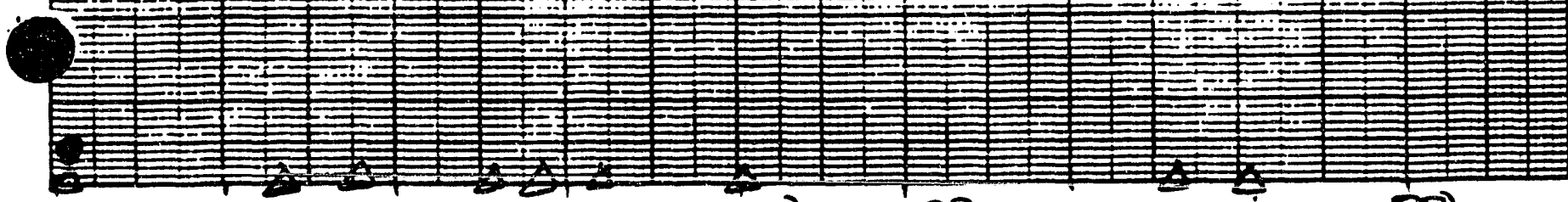


$\mathrm{RhCl}_{3}+$ Formic Acld

(0.12 $\mathrm{mmol}$ )

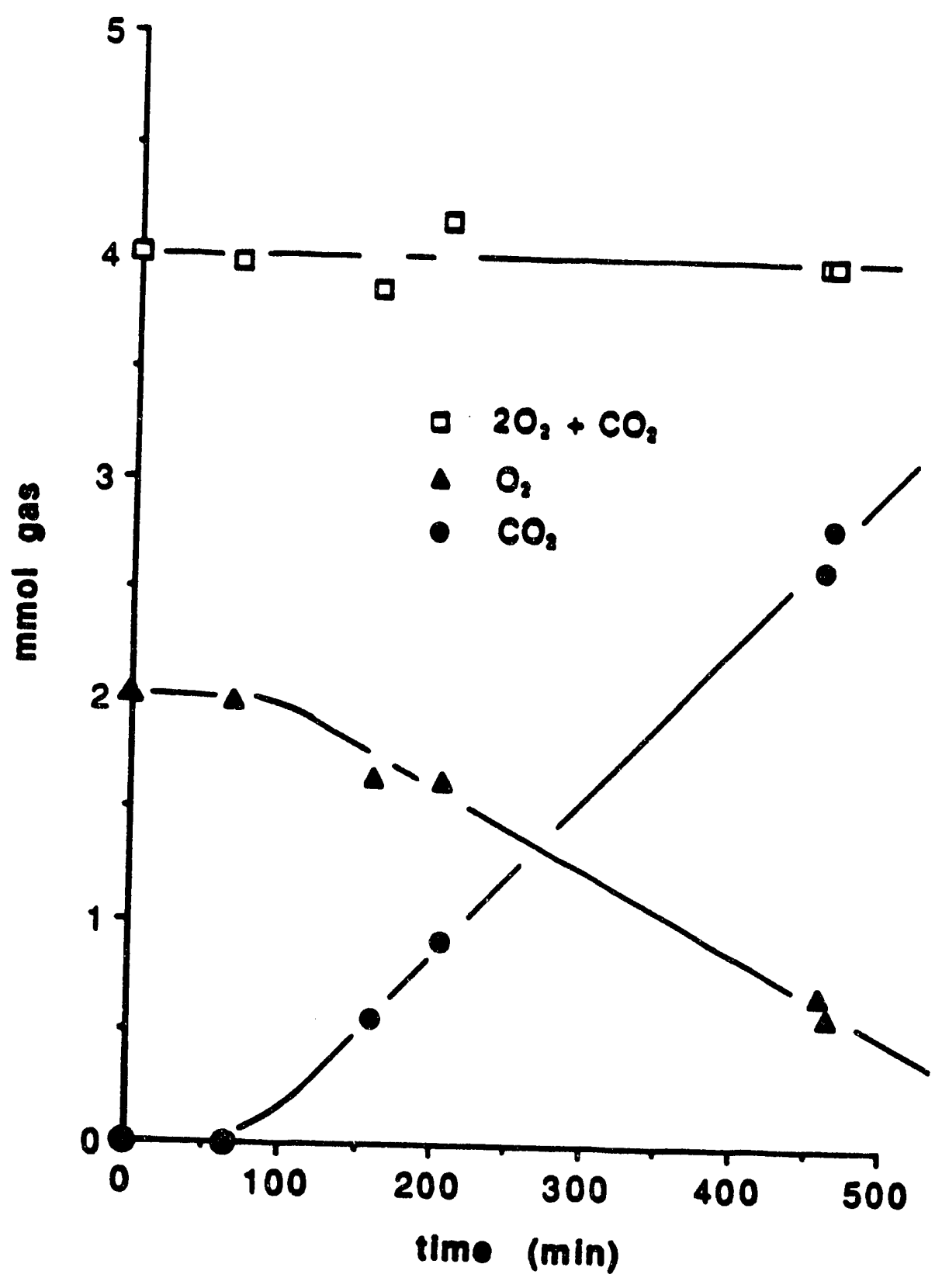

Fis (2) 


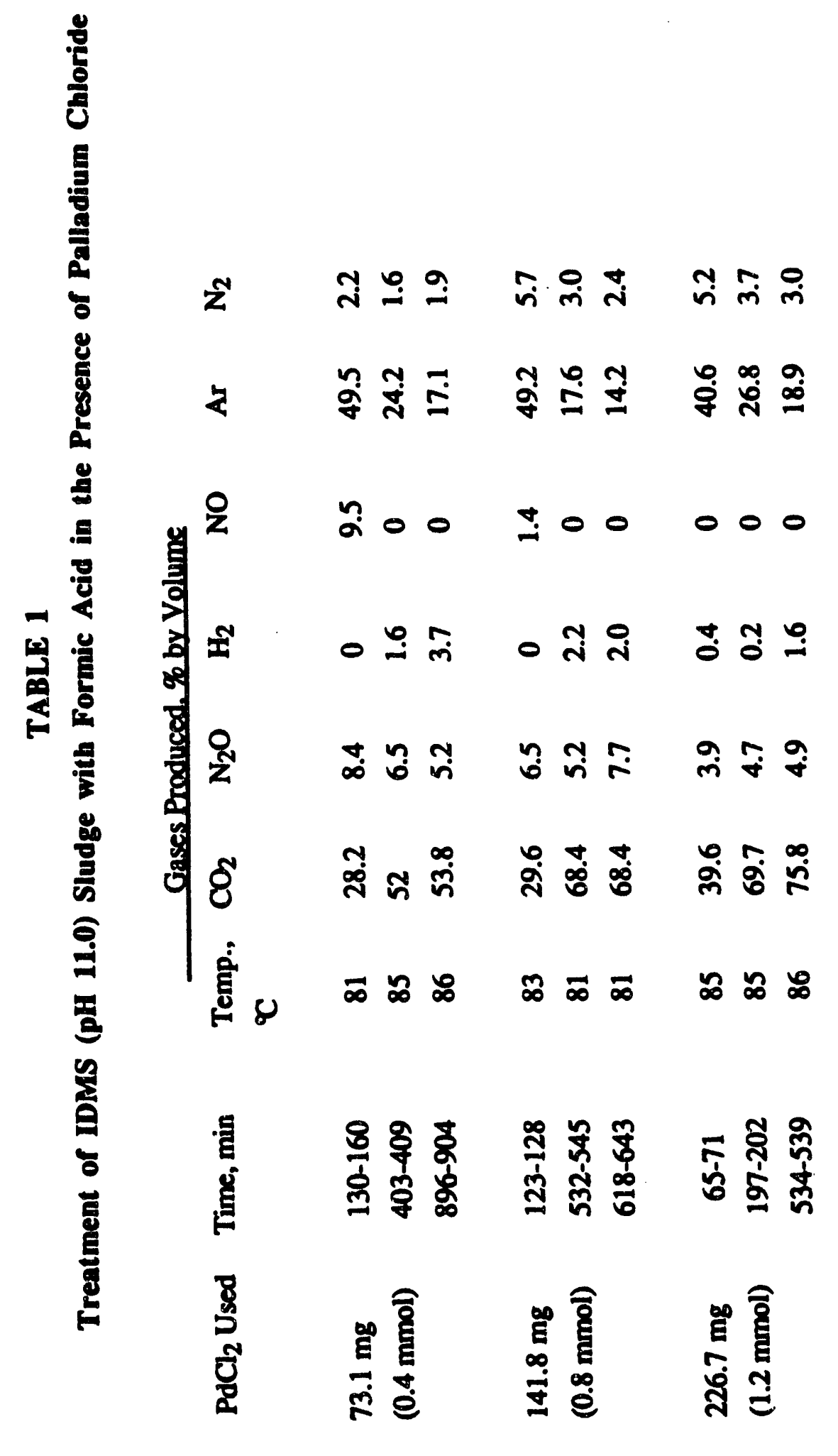




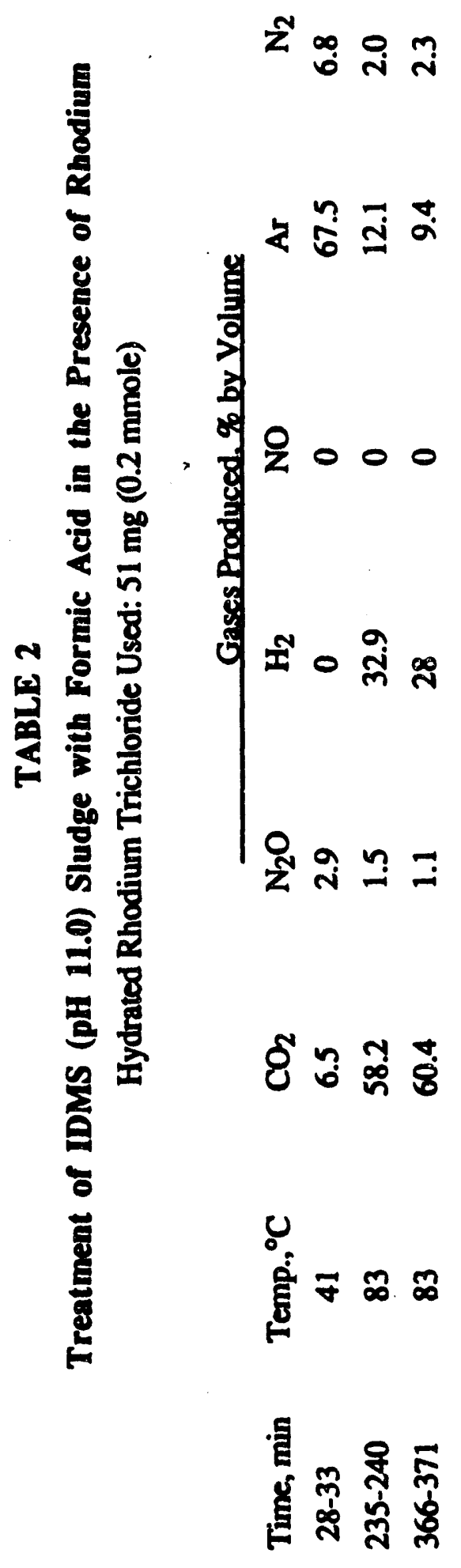




\title{
TECHNICAL REPORT
}

to the

Westinghouse Savannah River Laboratory

Aiken, South Carolina

\section{ELUCIDATION OF NÖBLE METAL/FORMIC ACID CHEMISTRY DURING DWPF FEED PREPARATION}

\author{
by
}

R. B. King, Regents' Professor and Principal Investigator

A. D. King, Jr., Professor and Faculty Associate

N. K. Bhattacharyya, Post-Doctoral Fellow

Y.-H. Lim, Graduate Student

G. Vemparala, Graduate Student

\section{Report 4}

June, 1991

Revised July, 1991

\begin{abstract}
:
Two noble metal systems have been found to be active catalysts for the decomposition of formic acid to evolve hydrogen at $80^{\circ} \mathrm{C}$ : (1) Rhodium in the presence of nitrite; (2) Palladium in basic media. The rhodium catalyst system is inhibited completely by ethylenediamine tetraacetic acid (EDTA) but not by dimethylglyoxime or oxalic acid whereas the palladium catalyst system is unaffected by EDTA. Upon treatment of IDMS (pH 11.0) DWPF sludge simulant with formic acid at $80-90^{\circ} \mathrm{C}$ ihodium catalyzes the rapid evolution of hydrogen, palladium catalyzes the slow evolution of hydrogen, and ruthenium is catalytically inactive.
\end{abstract}

Addendum (July, 1991). The composition of the IDMS $(\mathrm{pH}=11.0)$ sludge simulant used in this work is given in Table 1. 
Table 1

Composition of the IDMS (pH 11.0) HM Sludge Simulant Used in this Work

\begin{tabular}{|c|c|}
\hline & Amount, $\%$ by weight \\
\hline $\mathrm{Al}(\mathrm{OH})_{3}$ & 25.031 \\
\hline $\mathrm{BaSO}_{4}$ & 0.219 \\
\hline $\mathrm{Ca}_{3}\left(\mathrm{PO}_{4}\right)_{2}$ & 0.097 \\
\hline $\mathrm{CaCO}_{3}$ & 1.478 \\
\hline $\mathrm{CaSO}_{4}$ & 0.000 \\
\hline $\mathrm{Cr}_{2} \mathrm{O}_{3}$ & 0.220 \\
\hline $\mathrm{CsNO}_{3}$ & 0.028 \\
\hline $\mathrm{CuO}$ & 0.054 \\
\hline $\mathrm{Fe}(\mathrm{OH})_{3}$ & 25.893 \\
\hline $\mathrm{Nd}_{2} \mathrm{O}_{3}$ & 2.342 \\
\hline KOH & 0.170 \\
\hline $\mathrm{MgO}$ & 0.342 \\
\hline $\mathrm{MnO}_{2}$ & 6.650 \\
\hline $\mathrm{Na}_{2} \mathrm{CO}_{3}$ & 0.107 \\
\hline $\mathrm{Na}_{2} \mathrm{SO}_{4}$ & 0.471 \\
\hline $\mathrm{Na}_{3} \mathrm{PO}_{4}$ & 0.041 \\
\hline $\mathrm{NaCl}$ & 0.476 \\
\hline $\mathrm{NaF}$ & 0.259 \\
\hline $\mathrm{NaI}$ & 0.000 \\
\hline $\mathrm{NaNO}_{2}$ & 12.083 \\
\hline $\mathrm{NaNO}_{3}$ & 0.478 \\
\hline $\mathrm{NaOH}$ & 1.367 \\
\hline $\mathrm{Ni}(\mathrm{OH})_{2}$ & 1.308 \\
\hline $\mathrm{PbSO}_{4}$ & 0.220 \\
\hline $\mathrm{SeO}_{2}$ & 0.002 \\
\hline $\mathrm{SiO}_{2}$ & 5.039 \\
\hline $\mathrm{SrCO}_{3}$ & 0.408 \\
\hline $\mathrm{TeO}_{2}$ & 0.028 \\
\hline Zeolites & 9.342 \\
\hline $\mathrm{ZnO}$ & 0.043 \\
\hline $\mathrm{ZrO}_{2}$ & 1.842 \\
\hline
\end{tabular}




\section{Table 2}

Summary of the Catalytic Activity of Noble Metals in Formic Acid Decomposition to Hydrogen

(Numbers are moles of $\mathrm{H}_{2}$ produced per day per mole of noble metal)

$\begin{array}{lll}\text { Buthenium } & \text { Rhodium } & \text { Palladium } \\ \text { Hydrated } \mathrm{RuCl}_{3} & \text { Hydrated } \mathrm{RhCl}_{3} & \mathrm{PdCl}_{2}\end{array}$

\begin{tabular}{|c|c|c|c|}
\hline 88\% Formic Acida & Active & Inactive & Inactive \\
\hline 3.3\% Formic Acid & 4 & 0 & 3 \\
\hline $3 \% \mathrm{HCO}_{2} \mathrm{H} / \mathrm{NaNO}_{2}$ & 3 & 118 & 5 \\
\hline $0.76 \mathrm{M} \mathrm{NaCO}_{2} \mathrm{H}$ & 40 & 2.4 & 78 \\
\hline $\begin{array}{l}\text { IDMS sludge } \\
\text { simulant (pH 11.0) }\end{array}$ & 0 & 112 & 8 \\
\hline
\end{tabular}

(a) Data taken from Technical report 1 prepared March, 1991, entitled Preliminary Evaluation of Noble Metals as Catalysts for the Decomposition of Formic Acid. 


\section{Table 3}

Effect of Additives on the Catalytic Activity of Rhodium

in Formic Acid Decomposition to Hydrogen

(Numbers are moles of $\mathrm{H}_{2}$ produced per mole of noble metal)

mmoles $\mathrm{Rh}$

$$
\text { mmoles }
$$

$\mathrm{NaNO}_{2}$ mmoles Additive additive
Turnover per

Tempic $24 \mathrm{hr}$

A. Experiments with $0.76 \mathrm{M}$ Aqueous Sodium Formate:
0.2
0
none
0
95
2.4

B. Experiments with $0.76 \mathrm{M}$ Aqueous Formic Acid:

$\begin{array}{rlcllr}0.19 & 0 & \text { none } & 0 & 83 & 0 \\ 0.22 & 1.16 & \text { none } & 0 & & 118 \\ 0.21 & 1.18 & \text { dimethylglyoxime } & 0.44 & 90 & 167 \\ 0.19 & 1.17 & \text { oxalic acid } & 0.41 & 95 & 79 \\ 0.20 & 1.17 & \text { EDTA } & 0.43 & 85 & 0\end{array}$

C. Experiments with the IDMS (pHU.0) Sludge Simulant (see Table 1)

$\begin{array}{llcllr}0.18 & 0 & \text { none } & 0 & 82 & 112 \\ 0.21 & 0 & \text { air } & & 84 & 100 \\ 0.19 \mathrm{a} & 0 & \mathrm{Na}_{2} \mathrm{~S} & 2.17 & & \text { high } \\ 0.21 & 0 & \mathrm{TeO}_{2} & 2.0 & 80 & 62 \\ 0.20 & 0 & \left(\mathrm{MeO}_{3} \mathrm{P}\right. & 2.0 & 82 & 117 \\ 0.13 & 0 & \mathrm{HgCl}_{2} & 0.97 & 85 & 7\end{array}$

QQuantitative data could not be obtained because refluxing liquid punctured the safety device. However, rapid $\mathrm{H}_{2}$ production was observed during the fist few minutes. 


\section{Introciustion}

The simulated feed preparation for the glass melter operation at the Westinghouse Savannah River Laboratory (WSRL/TNX) is now in pilot-scale campaigning in support of the Defense Waste Processing Facility (DWPF). In order to simulate the presence of transition metal fission by-products in actual high level nuclear waste, the four noble metals $\mathrm{Ru}, \mathrm{Rh}, \mathrm{Pd}$, and $\mathrm{Ag}$ as their chloride or nitrate salts are now being added to DWPF sludge simulant. Metal constituents in the sludge are reduced and, in most cases, solubilized by addition of formic acid. The primary reason for using formic acid rather than another acid is the reduction of $\mathrm{Hg}^{2+}$ to elemental mercury for removal from the feed prior to glass melter simulations. After formic acid addition, the mixture is heated to $101^{\circ} \mathrm{C}$ to bring the reaction to completion. During this heating period, recent campaigns at the TNX pilot facility have observed gaseous hydrogen in the off gases.

The general objectives of this research project are the elucidation of the origin of this hydrogen production and the development of practical methods for its inhibition. In the initial phase of this research, presented in the first technical report, ${ }^{1}$ salts of the noble metals of interest were scouted as catalysts for the decomposition of $88 \%$ formic acid at $80^{\circ} \mathrm{C}$. Under these conditions only Ru (and Ir) were found to be catalytically active for the production of hydrogen and even the catalytic activity of $R u$ was rather limited. The next phase of this research 2,3 involved a study of the effects of noble metals on hydrogen evolution when the IDMS ( $\mathrm{pH} 11.0$ ) sludge simulant was treated with formic acid at $80^{\circ} \mathrm{C}$. The composition of this sludge simulant is given in Table 1. To our surprise rhodium (introduced as $\mathrm{RhCl}_{3} \cdot \mathrm{H}_{2} \mathrm{O}$ ) was an active catalyst for hydrogen evolution from the sludge simulant under these conditions even though it was inactive as a catalyst for hydrogen evolution from pure formic acid at the same temperature. Apparently some component of the sludge simulant was critical in promoting the catalytic activity of rhodium for the decomposition of formic acid. Major objectives during this phase of the research project were to elucidate the components in the sludge simulant responsible for promoting this catalytic activity of the rhodium and to find practical means for suppressing this

\footnotetext{
${ }^{1}$ Technical report 1 prepared March, 1991, entitled Preliminary Evaluation of Noble Metals as Catalysts for the Decomposition of Formic Acid.

${ }^{2}$ Technical report 2 prepared April, 1991.

${ }^{3}$ Technical report 3 prepared May, 1991.
} 
unwanted hydrogen evolution. The research described in this report can be divided into the following areas: (1) Experiments using the IDMS (pH 11.0) sludge simulant (Table 1); (2) Experiments using 3.3\% formic acid in order to elucidate the effect of formic acid concentration on trie catalytic activity; (3) Experiments using $0.76 \mathrm{M}$ sodium formate solution in order to elucidate the effects of $\mathrm{pH}$ on the catalytic activity. The general experimental techniques particularly with respect to the gas analyses are described in the earlier reports. A summary of some of the results from these experiments is given in Tables 2 and 3. The results are frequently reported in terms of the turnover number for $\mathrm{H}_{2}$ production, i.e. the moles of $\mathrm{H}_{2}$ produced per day per mole of metal. Since all of the experiments wert done with $40 \mathrm{~mL}$ of solution the reported turnover numbers can be converted to productivity per milliliter by dividing by 40 .

\section{Experiments with the IDMS (pH 11.0) Sludge Simulant}

\section{Experimental Procedure}

The IDMS (pH 11.0) sludge (38.5 mL) and $88 \%$ formic acid (1.5 mL) were placed in a $250 \mathrm{~mL}$ flask equipped with an adapter connected to a rubber septum. The mixture was flushed with argon for approximately 10 minutes. To this mixture a weighed quantity of the metal compound was added against an argon countercurrent. The solution was stirred and gas samples were analyzed. The solution was then warmed to $\sim 80^{\circ} \mathrm{C}$ and gas samples were analyzed by the standard methods. 1

The presence of large quantities of carbonates and nitrites in the sludge (Table 1) led to the rapid build up of gas pressure, which caused leakage problems. In some experimer.ts when the gas pressure inside the flask reached $\sim 1.3 \mathrm{~atm}$. the system was flushed with argon. After completing the flushing, gas samples were analyzed until the pressure again reached 1.3 atmospheres.

\section{Results}

Experiments with the effect of various metals on the treatment of the DMS (pH 11.0) siudge simulant with formic acid:

1) a) $\mathrm{RhCl}_{3}\left(0.18\right.$ mmole) gave a turnover number of 112 day-1 $^{-1}$ for $\mathrm{H}_{2}$ production at $82^{\circ} \mathrm{C}$. The $\mathrm{pH}$ at the end of the experiment was 6.94 . 
b) $\mathrm{RhCl}_{3}$ (0.22 mmoles) gave a turnover number of 142 day-1 for $\mathrm{H}_{2}$ production at $84^{\circ} \mathrm{C}$. The $\mathrm{pH}$ at the end of the experiment was 6.60 .

(2) $\mathrm{RhCl}_{3}\left(0.21\right.$ mmoles) was heated for $100 \mathrm{~min}$. No $\mathrm{H}_{2}$ was produced at this point. The mixture was then flushed with air. Subsequent heating for the next $100 \mathrm{~min}$. at $80^{\circ} \mathrm{C}$ gave a turnover number of 366 day-1 $^{-1}$ for $\mathrm{H}_{2}$ production. The mixture was again flushed

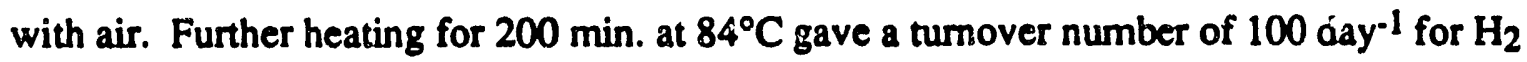
production. The $\mathrm{pH}$ at the end of the experiment was 6.5.

(3) $\mathrm{CuCl}_{2}(0.35 \mathrm{mmol})$ was heated for $\sim 330 \mathrm{~min}$. at $84^{\circ} \mathrm{C}$. The gas mixture at this point contained only $0.4 \% \mathrm{H}_{2}$. The $\mathrm{pH}$ at the end of the experiment was 3.6.

(4) $\mathrm{PdCl}_{2}(0.43 \mathrm{mmol})$ gave a turnover number of 8 day-1 for $\mathrm{H}_{2}$ production at $84^{\circ} \mathrm{C}$. The $\mathrm{pH}$ at the end of the experiment was 6.7.

Effect of potential catalyst poisons on the hydrogen evolution from the treatment of sludge simulant, with formic acid in the presence of $\mathrm{RhCl}_{3}$ :

The reaction conditions were basically the same as described above. The only difference was that a weighed amount of the potential catalyst poison was added to the sludge along with the $\mathrm{RhCl}_{3}$.

(1) Sodium Sulfide: $\mathrm{RhCl}_{3}\left(0.19\right.$ mmoles) and $\mathrm{Na}_{2} \mathrm{~S}$ (2.17 mmoles) were used. This reaction could not be monitored for a long period because refluxing liquid punctured the rubber safety device. However, $\mathrm{H}_{2}$ production was observed during the first few minutes.

(2) Tellurium Dioxide: In order to evaluate tellurium as a possible poison for the rhodium catalyst 2.0 mmoles of $\mathrm{TeO}_{2}$ was added to the mixture of sludge and formic acid and the mixture was heated for $4 \mathrm{hr}$. The reaction mixture was then flushed with argon and $0.21 \mathrm{mmoles}$ of $\mathrm{RhCl}_{3}$ was added. No nitric oxide was observed after the addition of $\mathrm{RhCl}_{3}$. The average $\mathrm{H}_{2}$ production was 62 day-1 at $^{-1} 80^{\circ} \mathrm{C}$. The $\mathrm{pH}$ at the end of the experiment was 6.46. However, in a separate experiment, when $\mathrm{RhCl}_{3}$ and $\mathrm{TeO}_{2}$ were added together, there was a burst of $\mathrm{H}_{2}$ which caused leakage problems. After purging with argon for $1 \mathrm{~min}$. the rate of $\mathrm{H}_{2}$ production dropped off dramatically.

(3) Trimethyl Phosphite: $\mathrm{RhCl}_{3}$ (0.20 mmoles) and trimethyl phosphite (2.0

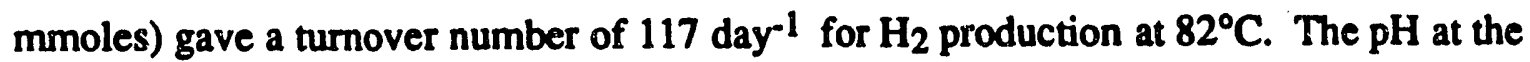
end of the experiment was 8.48 .

(4) Mercuric Chloride: $\mathrm{HgCl}_{2}$ (0.97 mmoles) was added to a mixture of the sludge simulant and formic acid. The mixture was heated to $85^{\circ} \mathrm{C}$ for $7 \mathrm{hr}$, cooled to room temperature, flushed with argon, and then 0.13 mmoles of $\mathrm{RhCl}_{3}$ was added. The initial 
turnover rate for $\mathrm{H}_{2}$ production was 7 day $^{-1}$. The $\mathrm{pH}$ at the end of the experiment was 6.01 .

\section{Experiments Using 0.76 M Aqueous Formic Acid}

\section{Experimental Procedure}

Distilled water $(38.5 \mathrm{~mL}$ ) and $88 \%$ formic acid $(1.5 \mathrm{~mL})$ to give $0.76 \mathrm{M}$ formic acid with a pH of 1.63 were placed in a $250 \mathrm{~mL}$ flask equipped with an adapter connected to a rubber septum. The system was flushed with argon for approximately 10 minutes. To this mixture a weighed quantity of the metal salt was added against a countercurrent of argon. The gas phase was analyzed both at room temperature and at higher temperatures.

\section{Results}

Experiments on the effects of various metals on the decomposition of 0.76 $M$ aqueous formic acid:

(1) Palladium: $\mathrm{PdCl}_{2}\left(0.44\right.$ mmoles) at $90^{\circ} \mathrm{C}$ led to an average turnover of 3 day-1 for $\mathrm{H}_{2}$ production. At the end of the reaction there was a black precipitate and the $\mathrm{pH}$ was 1.35 .

(2) Ruthenium: Hydrated ruthenium trichloride $\left(0.23\right.$ mmoles) at $90^{\circ} \mathrm{C}$ led to an average turnover of 4 day $^{-1}$ for $\mathrm{H}_{2}$ production. At the end of the experiment the solution was clear and yellow-green and the $\mathrm{pH}$ was 1.45 .

(3) Rhodium: Hydrated $\mathrm{RhCl}_{3}$ (0.19 mmoles) did not produce significant quantities of $\mathrm{H}_{2}$ at $83^{\circ} \mathrm{C}$. At the end of the experiment there was a black precipitate and the $\mathrm{pH}$ was 1.45 .

Experiments on the effects of various metals on the decomposition of 0.76 $M$ aqueous formic acid in the presence of nitrite ion:

(1) Palladium: $\mathrm{PdCl}_{2}$ (0.47 mmoles) and $\mathrm{NaNO}_{2}\left(1.90\right.$ mmoles) at $90^{\circ} \mathrm{Cled}$ to an initial turnover of 5 day-1 $^{-1}$ for $\mathrm{H}_{2}$ production. At the end of the experiment there was a black precipitate and the $\mathrm{pH}$ was 2.16 . 
(2) Ruthenium: Hydrated ruthenium trichloride (0.21 mmoles) and $\mathrm{NaNO}_{2}$ (1.15 mmoles) at $95^{\circ} \mathrm{C}$ led to an initial turnover number of 3 day-1 for $\mathrm{H}_{2}$ production. At the end of the experiment the $\mathrm{pH}$ was 2.04 and the solution was light red with no precipitate.

(3) Rhodium: Hydrated $\mathrm{RhCl}_{3}$ (0.22 mmoles) and $\mathrm{NaNO}_{2}$ (1.16 mmoles) led to an initial turnover number of 118 day-1 $^{-1}$ for $\mathrm{H}_{2}$ production. This $\mathrm{H}_{2}$ was produced in a burst and led to leakage problems. The mixture therefore had to be flushed with argon. After flushing the rate of $\mathrm{H}_{2}$ production dropped to 5-6 day-1. At the end of the experiment the $\mathrm{pH}$ was 1.94 and the solution contained a black precipitate.

Experiments on the effects of various complexing agents on the decomposition of $0.76 \mathrm{M}$ aqueous formic acid by rhodium trichloride in the presence of nitrite ion:

(1) Dimethylglyoxime: Hydrated $\mathrm{RhCl}_{3}$ (0.21 mmoles), $\mathrm{NaNO}_{2}$ (1.18 mmoles), and dimethylglyoxime ( 0.44 mmoles) led to turnovers of 92,183 , and 167 day-1 at 80 , 85 , and $90^{\circ} \mathrm{C}$, respectively, for $\mathrm{H}_{2}$ production during the first 175 minutes, the next 72 minutes after an argon flush, and the next 95 minutes after a second argon flush. At the end of the experiment the $\mathrm{pH}$ was 2.29 and there was a black precipitate.

(2) Oxalic Acid: Hydrated $\mathrm{RhCl}_{3}$ (0.19 mmoles), $\mathrm{NaNO}_{2}$ (1.17 mmoles), and oxalic acid ( 0.41 mmoles) led to a turnover of 79 day $^{-1}$ for $\mathrm{H}_{2}$ production at $95^{\circ} \mathrm{C}$. At the end of the experiment the $\mathrm{pH}$ was 1.96 and there was a black precipitate.

(3) Ethylenediamine Tetraacetic Acid (EDTA): Hydrated $\mathrm{RhCl}_{3}(0.20$ mmoles), $\mathrm{NaNO}_{2}$ (1.17 mmoles), and EDTA (0.43 mmoles) led to insignificant $\mathrm{H}_{2}$ production over a period of 475 minutes at $85^{\circ} \mathrm{C}$. At the end of the reaction period the $\mathrm{pH}$ was 1.99 and the solution was a clear lemon yellow. The EDTA thus appeared to inhibit both the $\mathrm{H}_{2}$ production from formic acid by the $\mathrm{RhCl}_{3} / \mathrm{NaNO}_{2}$ system as well as the reduction to thodium metal.

\section{Experiments Employing 0.76 M Sodium Formate}

\section{Experimental Procedure}

A $0.76 \mathrm{M}$ sodium formate solution (same molarity as that of formic acid in the previous series of experiments) was made by dissolving $2.06 \mathrm{~g}$. of sodium formate in 250 mL of distilled water. The pH of the solution was 7.92. The solution was flushed with argon for 10 minutes and then a weighed quantity of the metal salt was added against a 
countercurrent of argon. Gas samples were analyzed both a room temperature and higher temperatures.

\section{Results}

(1) Ruthenium: Hydrated ruthenium trichloride $(0.21 \mathrm{mmoles})$ at $95^{\circ} \mathrm{C}$ led to an initial burst of $\mathrm{H}_{2}$. The turnover of $\mathrm{H}_{2}$ production then slowed down to $40 \mathrm{day}^{-1}$. At the end of the experiment the solution contained a black precipitate and the $\mathrm{pH}$ was 8.02 .

(2) Ruthenium with added EDTA: Hydrated ruthenium trichloride $(0.21 \mathrm{mmoles})$ in the presence of 0.42 mmoles of EDTA at $95^{\circ} \mathrm{C}$ led to the smooth production of $\mathrm{H}_{2}$ with a

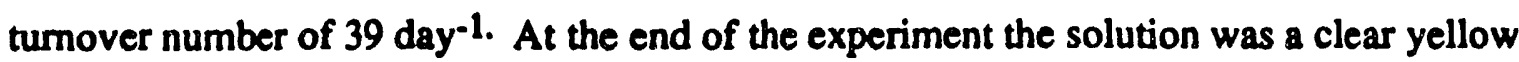
and the $\mathrm{pH}$ was $\mathbf{5 . 5 2}$.

(3) Rhodium: Hydrated $\mathrm{RhCl}_{3}\left(0.2\right.$ mmoles) at $95^{\circ} \mathrm{C}$ led to a turnover of 2.4 day-1 for $\mathrm{H}_{2}$ production. At the end of the experiment the solution contained a black precipitate and the $\mathrm{pH}$ was 6.64 .

(4) Palladium: $\mathrm{PdCl}_{2}$ ( 0.46 mmoles) when placed into the sodium formate solution led to the immediate formation of black particles. The turnover for $\mathrm{H}_{2}$ production was 78 day 1 at $88^{\circ} \mathrm{C}$ for the first $137 \mathrm{~min}$. and 20 day $^{-1}$ for the next 212 minutes after an argon flush. At the end of the experiment the solution contained a black precipitate and its $\mathrm{pH}$ was 9.05 .

(5) Palladium with added EDTA: $\mathrm{PdCl}_{2}(0.45$ mmoles) in the presence of 0.9 mmoles of added EDTA resulted in the immediate formation of a black precipitate. The turnovers for $\mathrm{H}_{2}$ production were 107,256 , and 74 day $^{-1}$ for the first 79 minutes, the next 52 minutes after an argon flush, and the next 82 minutes after a second argon flush. At the end of the experiment the solution contained a black precipitate and its $\mathrm{pH}$ was 9.06 .

(6) Palladium with added $\mathrm{NaNO}_{2}: \mathrm{PdCl}_{2}$ ( 0.45 mmoles) in the presence of 1.9 mmoles of added $\mathrm{NaNO}_{2}$ led to turnovers of 53 and 29 day $^{-1}$, respectively, for $\mathrm{H}_{2}$ production at $93^{\circ} \mathrm{C}$ initially and after an argon flush.

\section{Discussion}

Previous experiments ${ }^{3}$ have shown that addition of $\mathrm{RhCl}_{3}$ to the $\mathrm{IDMS}(\mathrm{pH} 11.0$ ) sludge simulant before formic acid treatment leads to the copious evolution of $\mathrm{H}_{2}$ upon heating to $\sim 80^{\circ} \mathrm{C}$ whereas heating aqueous $90 \%$ formic acid with $\mathrm{RhCl}_{3}$ under similar conditions led to no $\mathrm{H}_{2}$ evolution. We have now shown that addition of sodium nitrite to a solution of $\mathrm{RhCl}_{3}$ in aqueous formic acid leads to rapid evolution of $\mathrm{H}_{2}$ upon heating. This suggests that the nitrite ion present in the IDMS sludge simulant is responsible for this 
difference in behavior. An aqueous solution of $\mathrm{RhCl}_{3}$ is known ${ }^{4}$ to react with nitrite ion to give the hexanitrorhodate(III) anion, $\mathrm{Rh}\left(\mathrm{NO}_{2}\right)_{6}{ }^{3-}$. Furthermore three of the nitro ligands in $\mathrm{Rh}\left(\mathrm{NO}_{2}\right)_{6}{ }^{3-}$ are known to be labile 5.6 towards substitution giving, for example, $\mathrm{Rh}\left(\mathrm{NO}_{2}\right)_{3}\left(\mathrm{H}_{2} \mathrm{O}\right)_{3}$ upon acid hydrolysis. This suggests that trinitrorhodium(III) derivatives might play an important role in the catalytic processes leading to $\mathrm{H}_{2}$ evolution upon treatment of the sludge simulant with formic acid in the presence of rhodium. In addition, the catalytically active $\mathrm{RhCl}_{3} / \mathrm{NaNO}_{2}$ mixture gradually deposited rhodium metal upon treatment with formic acid. The effect of this on the catalytic activity of the system for $\mathrm{H}_{2}$ generation requires more work for its elucidation.

The objective of this research project is to find methods for inhibiting this unwanted production of $\mathrm{H}_{2}$. Therefore, various strongly coordinating ligands were evaluated as possible poisons for the $\mathrm{RhCl}_{3} / \mathrm{NaNO}_{2}$ catalyst system. In this connection, EDTA was found to suppress completely the production of $\mathrm{H}_{2}$ and thus merits further attention as a means of inhibiting $\mathrm{H}_{2}$ production in the actual sludges. The effect of EDTA on the $\mathrm{RhCl}_{3} / \mathrm{NaNO}_{2} / \mathrm{HCO}_{2} \mathrm{H}$ system was not only the complete inhibition of $\mathrm{H}_{2}$ production but also the complete inhibition of the reduction to rhodium metal. Thus a solution of $\mathrm{RhCl}_{3} / \mathrm{NaNO}_{2} / \mathrm{HCO} / \mathrm{H}$ upon boiling with EDTA remained yellow.

Some experiments using formate ion rather than formic acid were initiated. In this connection sodium formate was found to reduce $\mathrm{PdCl}_{2}$ rapidly to palladium metal and then rapid $\mathrm{H}_{2}$ evolution began. The $\mathrm{H}_{2}$ production from sodium formate by palladium was not inhibited by EDTA.

The results summarized in this report suggest that EDTA might have potential in inhibiting the unwanted $\mathrm{H}_{2}$ production from the sludge simulant by treatment with formic acid in the presence of rhodium. Further experiments are planned during the next several weeks in order to find whether the many other components of the sludge simulant (Table 1) interfere with the inhibition by EDTA. Thus the many metals other than the noble metals, e.g. Fe, Mn, Ni, etc., could complex preferentially with the EDTA thereby no longer making it an effective inhibitor.

${ }^{4}$ E. Leidie, Compt. Rend. 111, 106 (1890).

5V. S. Syrokomskii and N. P. Proshenkova, Zhur. Anal. Khim. 3, 274 (1947).

${ }^{6}$ A. V. Belyaev, Russ. J. Inorg. Chem. 12, 577 (1967). 


\title{
TECHNICAL REPORT
}

to the

Westinghouse Savannah River Laboratory

Aiken, South Carolina

on

\section{ELUCIDATION OF NOBLE METAL/FORMIC ACID CHEMISTRY DURING DWPF FEED PREPARATION}

by

R. B. King, Regents' Professor and Principal Investigator

A. D. King, Jr., Professor and Faculty Associate

N. K. Bhattacharyya, Post-Doctoral Fellow

L. Colletti, Graduate Student

G. Vemparala, Graduate Student

V. Vemparala, Graduate Student

\section{Report 5}

July, 1991

\begin{abstract}
This report discusses further studies on the rhodium-catalyzed decomposition of formic acid to give hydrogen in the temperature range $80-95^{\circ} \mathrm{C}$ and in the initial pH range of $\sim 3.5$. Experiments have been done both on ideal systems and on lownitrite Purex $(\mathrm{pH}=12)$ sludge simulant. The presence of nitrite ion appears to be essential for significant catalytic activity. Under such conditions turnover numbers in the range of 300-600 moles $\mathrm{H}_{2}$ /moles $\mathrm{Rh} /$ day have been observed. The production of $\mathrm{H}_{2}$ from the $\mathrm{NO}_{2}-/ \mathrm{Rh}$ systems is inhibited not only by EDTA but also by mercury, even in the elemental form.
\end{abstract}




\section{Experimental Conditions}

The reactions were conducted in $250 \mathrm{~mL}$ glass vessels equipped with a thread and O-ring adapter. A pressure gauge was attached to the system. The two side-arms of the vessel near the top were capped with rubber septa through which needles could be inserted to flush the system or for gas sampling purposes. The flask has two thermocouple wells: in one a thermocouple attached to a cycle heater was placed to maintain a constant temperature and the other well was used to check the temperature of the reaction mixture independently with a second thermocouple. In other experiments the glass vessel was heated with a hot water bath using a thermocouple to monitor the temperature.

\section{Experiments with Sludge Simulants (see Table 1)}

The experiments on the rhodium-catalyzed formic acid decomposition with the IDMS $\mathrm{pH}=11 \mathrm{HM}$ sludge simulant are summarized in Table 2. The effects of mercuric chloride and ethylenediamine tetraacetic acid (EDTA) as an inhibitor are documented. A strong temperature effect on the rate of $\mathrm{H}_{2}$ evolution was observed. Finally, an experiment at a much lower rhodium concentration ( 0.0056 mmoles) was performed. This latter experiment indicated that the turnover number at this much lower rhodium concentration more nearly corresponding to those estimated to be in the wastes to be treated in the DWPF plant is roughly similar to those obtained using 0.1 to 0.4 mmoles $R h$ under our standard experimental conditions.

Our supply of IDMS pH = $11 \mathrm{HM}$ sludge simulant was exhausted and we received some new sludge simulant designated as low nitrite purex $(\mathrm{pH}=12)$. Unfortunately, this new sludge simulant had a very different composition than the earlier sludge simulant (Table 1). The most significant difference in the composition of the new sludge simulant was the presence of only $1 / 5$ of the relative amount of nitrite as in the earlier sludge simulant. The presence of twice the relative amount of iron in the $\mathrm{pH}=12$ sludge simulant compared with the $\mathrm{pH}=11$ sludge simulant may also prove to be significant in view of the redox properties of the $\mathrm{Fe}^{\mathrm{II}} / \mathrm{Fe}^{\mathrm{II}}$ couple although the effect of this redox couple on the noble metal-catalyzed formic acid decomposition has not yet been investigated.

Our initial experiments with the rhodium-catalyzed formic acid decomposition in the low nitrite purex $(\mathrm{pH}=12)$ sludge simulant indicated high turnover numbers $(\sim 660$ moles $\mathrm{H}_{2}$ /mole $\mathrm{Rh} /$ day) as indicated in Figure 1. Insignificant amounts of $\mathrm{NO}$ or $\mathrm{N}_{2} \mathrm{O}$ were observed during this formic acid decomposition apparently reflecting the much lower nitrite concentration in the sludge simulant. At the end of these high-turnover formate decomposition reactions, the $\mathrm{pH}$ was in the range 6.2-6.4 reflecting the loss of the original 
formic acid. Interestingly enough, hydrogen production was completely inhibited by the addition of liquid mercury $\left([\mathrm{Hg} / /[\mathrm{Rh}]=11.5)\right.$. Thus the apparent inhibition of $\mathrm{H}_{2}$ production when $\mathrm{HgCl}_{2}$ was added to the system cannot simply be attributed to the easier reduction of $\mathrm{Hg}^{2+}$ to $\mathrm{Hg}^{0}$ relative to the reduction of $\mathrm{H}^{+}$to $\mathrm{H}_{2}$. The reaction of $\mathrm{Rh}$ (III) derivatives with elemental mercury to form $\mathrm{Rh}-\mathrm{Hg}$ complexes which inhibit the catalytic activity of nitrorhodium derivatives may be mechanistically significant.

\section{Study of the Effect of Nitrite Concentration on Hydrogen Production Catalyzed by Rhodium in Ideal Systems.}

A series of experiments was performed in a simple aqueous system using a $\left[\mathrm{NaCO}_{2} \mathrm{H}\right] /\left[\mathrm{HCO}_{2} \mathrm{H}\right]$ ratio of 0.64 corresponding to a $\mathrm{pH}$ of 3.5. The results are summarized in Figures 2A and 2B. In the absence of nitrite, the turnover number for $\mathrm{H}_{2}$ production was only $\sim 21$ mmoles of $\mathrm{H}_{2}$ per mmole of $\mathrm{Rh}$ per day and the production of $\mathrm{H}_{2}$ leveled off at 1.5 mmoles of $\mathrm{H}_{2}$ /mmole of $\mathrm{Rh}$ indicating very little catalytic activity. In the presence of nitrite at $\left[\mathrm{NO}_{2}-\right] /[\mathrm{Rh}]$ ratios of 10 to 20 , considerable $\mathrm{H}_{2}$ evolution was observed as indicated by turnover numbers of $\sim 300$ estimated from the straight line portions of the $\mathrm{H}_{2}$ evolution curves. 


\section{Table 1}

Composition of the IDMS and Purex Sludge Simulants IDMS pH $=11 \mathrm{HM}$ Sludge Low Nitrite Purex

Amount, $\%$ by weight

$$
(\mathrm{pH}=12) \text { Sludge }
$$

$\mathrm{Al}(\mathrm{OH})_{3}$

$\mathrm{BaSO}_{4}$

$\mathrm{Cs}_{3}\left(\mathrm{PO}_{4}\right)_{2}$

$\mathrm{CaCO}_{3}$

$\mathrm{CaSO}_{4}$

$\mathrm{Cr}_{2} \mathrm{O}_{3}$

$\mathrm{CsNO}_{3}$

$\mathrm{CuO}$

$\mathrm{Fe}(\mathrm{OH})_{3}$

$\mathrm{Nd}_{2} \mathrm{O}_{3}$

$\mathrm{KOH}$

$\mathrm{MgO}$

$\mathrm{MnO}_{2}$

$\mathrm{Na}_{2} \mathrm{CO}_{3}$

$\mathrm{Na}_{2} \mathrm{SO}_{4}$

$\mathrm{Na}_{3} \mathrm{PO}_{4}$

$\mathrm{NaCl}$

$\mathrm{NaF}$

$\mathrm{NaI}$

$\mathrm{NaNO}_{2}$

$\mathrm{NaNO}_{3}$

$\mathrm{NaOH}$

$\mathrm{Ni}(\mathrm{OH})_{2}$

$\mathrm{PbSO}_{4}$

$\mathrm{SeO}_{2}$

$\mathrm{SiO}_{2}$

$\mathrm{SrCO}_{3}$

$\mathrm{TeO}_{2}$

Zeolites

$\mathrm{ZnO}$

$\mathrm{ZrO}_{2}$
25.031

0.219

0.097

1.478

0.000

0.220

0.028

0.054

25.893

2.342

0.170

0.342

6.650

0.107

0.471

0.041

0.476

0.259

0.000

12.083

0.478

1.367

1.308

0.220

0.002

5.039

0.408

0.028

9.342

0.043

1.842
Amount, \% by weight

12.298

0.505

0.254

5.148

0.468

0.409

0.003

0.182

51.204

0.253

0.397

0.246

7.320

0.148

0.169

0.012

1.545

0.275

0.027

2.455

0.358

3.507

4.507

0.505

0.003

1.672

0.038

0.031

1.661

0.341

3.828 
Table 2

Experiments with IDMS pH $=11 \mathrm{HM}$ Sludge on the RhodiumCatalyzed Formic Acid Decomposition

mmoles $\mathrm{Rh}$

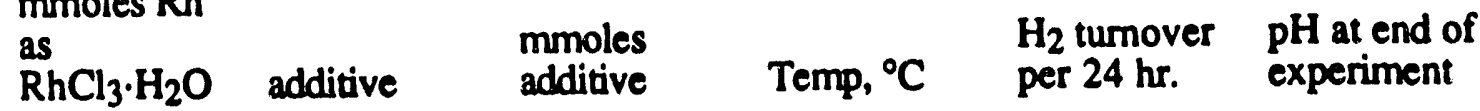
A. Effect of Potential Catalyst Poisons

0.2

EDTA

2.2

96

16

4.7

0.2

EDTA

21.5

95

0

2.9

0.2

$\mathrm{HgCl}_{2}$

2.0

96

1.3

6.0

0.2

$\mathrm{HgCl}_{2}$

19.6

96

0.01

3.8

B. Effect of Temperature on the Rate of $\mathrm{H}_{2}$ Production from IDMS ( $\mathrm{pH}=$ 11.0) Sludge

$\begin{array}{lllcc}0.21 & \text { none } & 70 & 0 & 6.9 \\ 0.21 & \text { none } & 80 \pm 2 & 2.5 & 5.2 \\ 0.20 & \text { none } & 90 \pm 2 & 144 & 7.4\end{array}$

C. Experiment with a Low Rhodium Concentration ( $\approx 0.02 \% \mathrm{Rh}$ in Sludge)

0.0056 none

95

55

5.4 


\section{Figure 1}

High Turnover Numbers of $\mathrm{H}_{2}$ Evolution from the Low Nitrite Purex ( $\mathrm{pH}=12$ ) Sludge with Rhodium

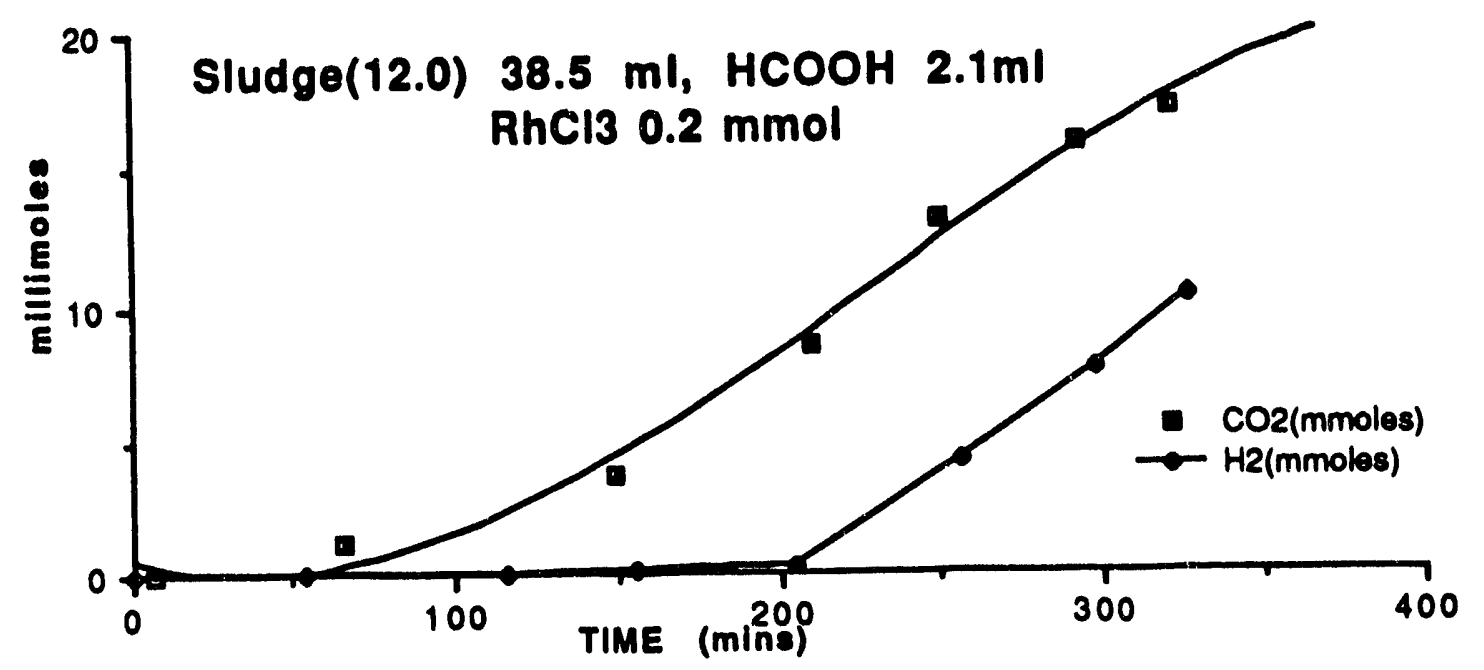

Turnover number $=580 \mathrm{mmoles} \mathrm{H}_{2} / \mathrm{mmole} \mathrm{Rh} / 24 \mathrm{hr}$. $\left(95^{\circ} \mathrm{C}\right)$

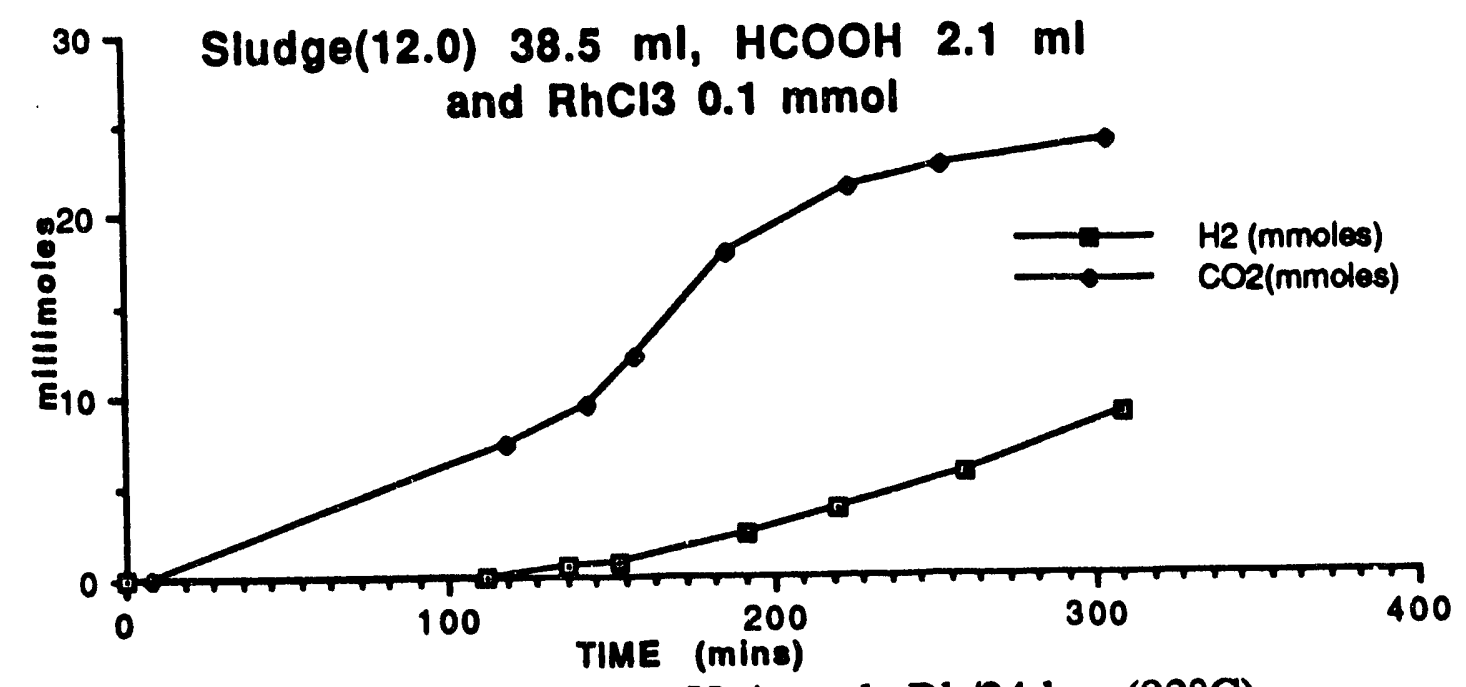

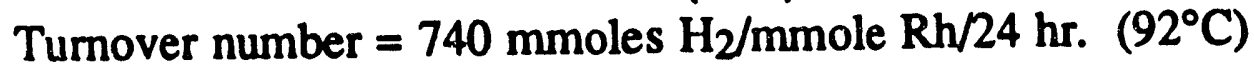

$\Rightarrow$ Reaction appears approximately first order in $\mathrm{Rh}$ with a turnover of $660 \pm 80 \mathrm{H} 2 / \mathrm{mmole} \mathrm{Rh} / 24 \mathrm{hr}$. 
Figure 2A

Effect of Nitrite Concentration on $\mathrm{H}_{2}$ Production when $\left[\mathrm{NaCO}_{2} \mathrm{H}\right] /\left[\mathrm{HCO}_{2} \mathrm{H}\right]=0.64(\mathrm{pH}=3.5)$

HCOONa $31.4 \mathrm{mmol}, \mathrm{HCOOH} 49.4 \mathrm{mmol}$

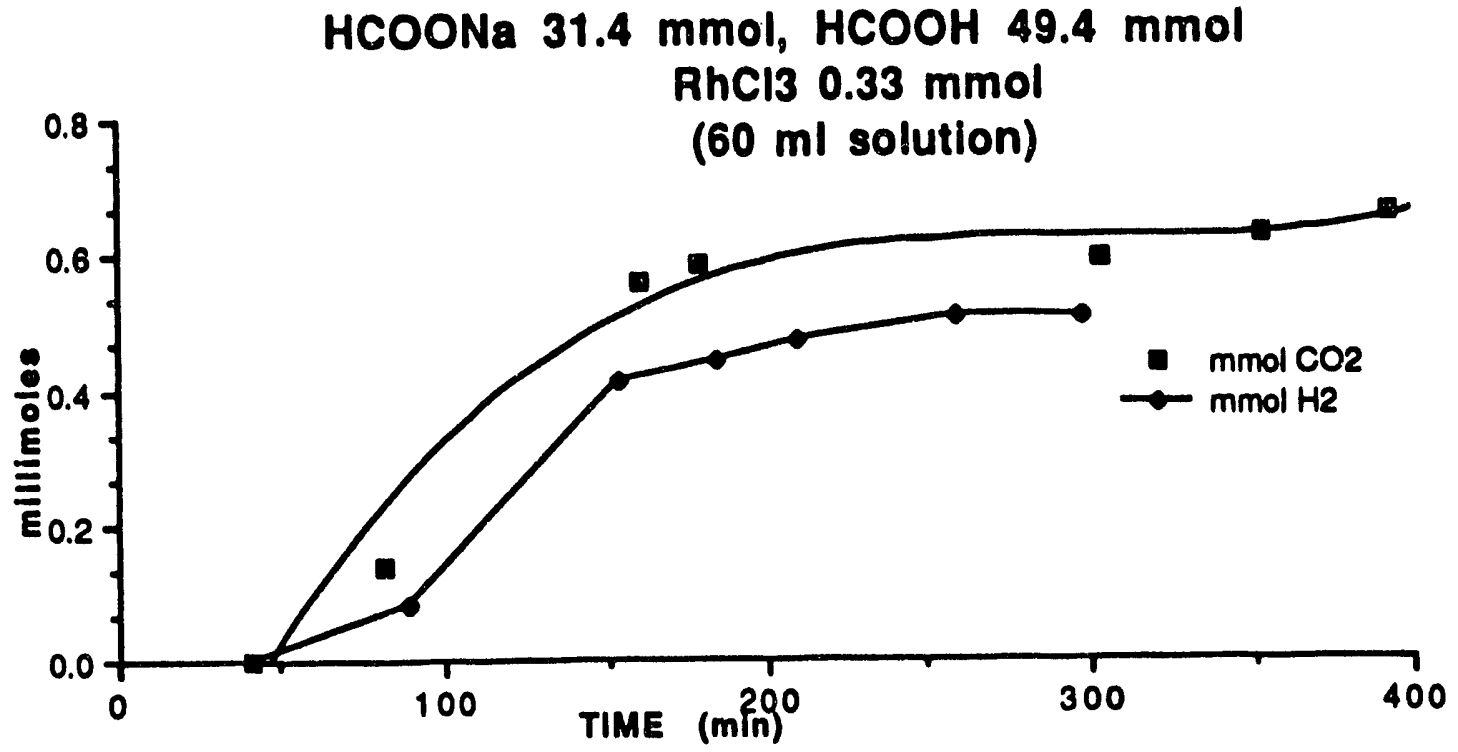

mmoles $\mathrm{H}_{2}$ at $\mathrm{end} / \mathrm{mmoles} \mathrm{Rh}=0.5 / 0.33 \approx 1.5 \quad\left(\right.$ at $90^{\circ} \mathrm{C}$ )

Turnover number $\sim 21$ mmoles $\mathrm{H}_{2} /$ mmole $\mathrm{Rh} /$ day

HCOONa $31.4 \mathrm{mmol}$, HCOOH $49.4 \mathrm{mmol}$

RhCl3 $0.33 \mathrm{mmol}$ and $\mathrm{NaNO} 23.91 \mathrm{mmol}$

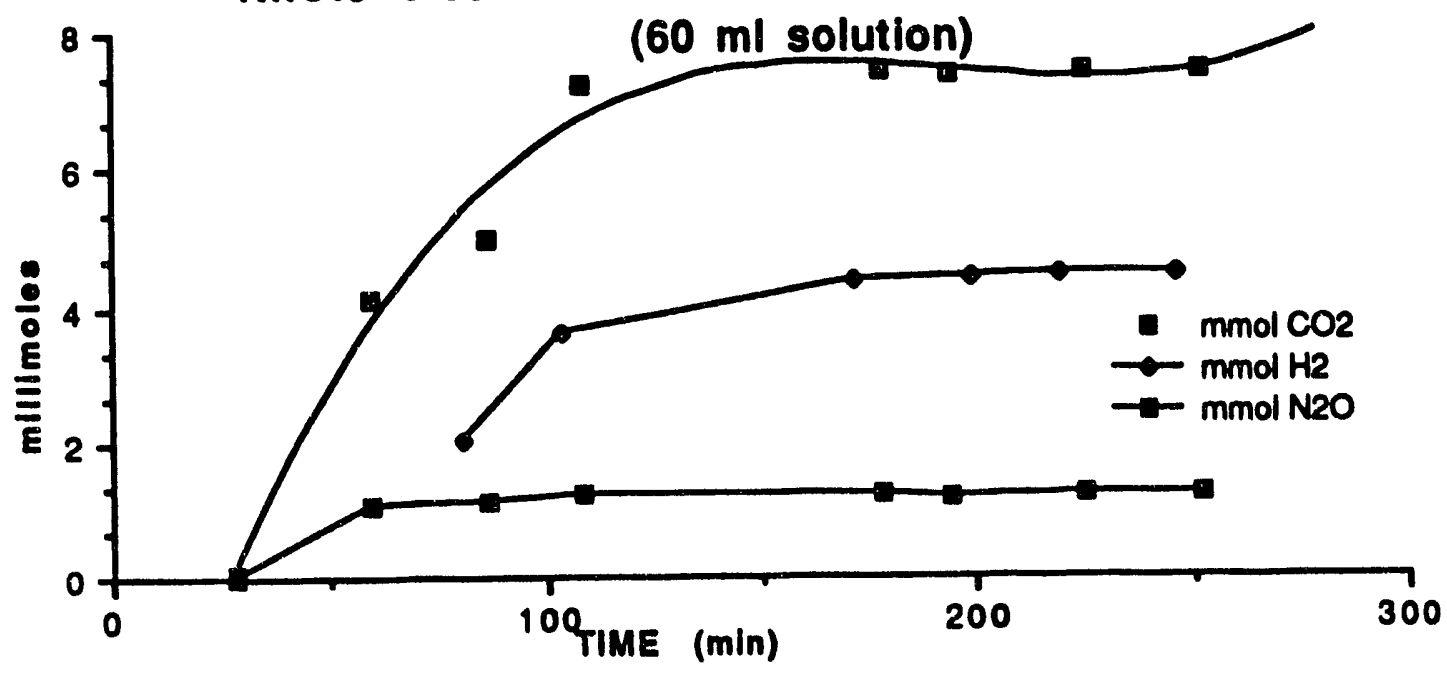

Turnover number $=275 \mathrm{moleH} / \mathrm{mole} \mathrm{Rh} /$ day at $83^{\circ} \mathrm{C}$ 
Figure 2B

Effect of Nitrite Concentration on $\mathrm{H}_{2}$ Production when $\left[\mathrm{NaCO}_{2} \mathrm{H}\right] /\left[\mathrm{HCO}_{2} \mathrm{H}\right]=0.64(\mathrm{pH}=3.5)$

HCOONa $31.4 \mathrm{mmol}$, HCOOH $49.4 \mathrm{mmol}$

RhCl3 $0.33 \mathrm{mmol}$ and $\mathrm{NaNO2} 7.82 \mathrm{mmol}$

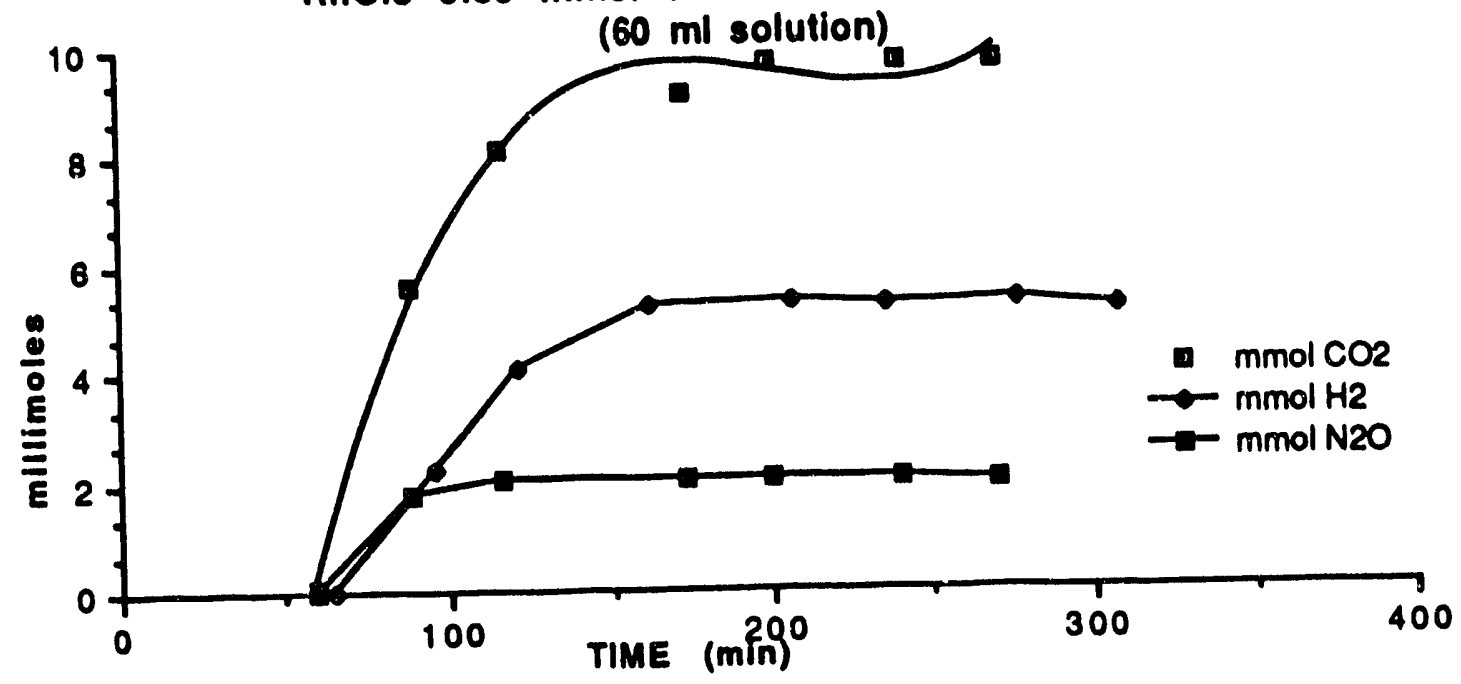

Turnover number $=275$ moles $\mathrm{H}_{2} /$ mole $\mathrm{Rh} /$ day

HCOONa $31.4 \mathrm{mmol}$, HCOOH $49.4 \mathrm{mmol}$

RhCl3 $0.2 \mathrm{mmol}$ and NaNO2 $3.9 \mathrm{mmol}$

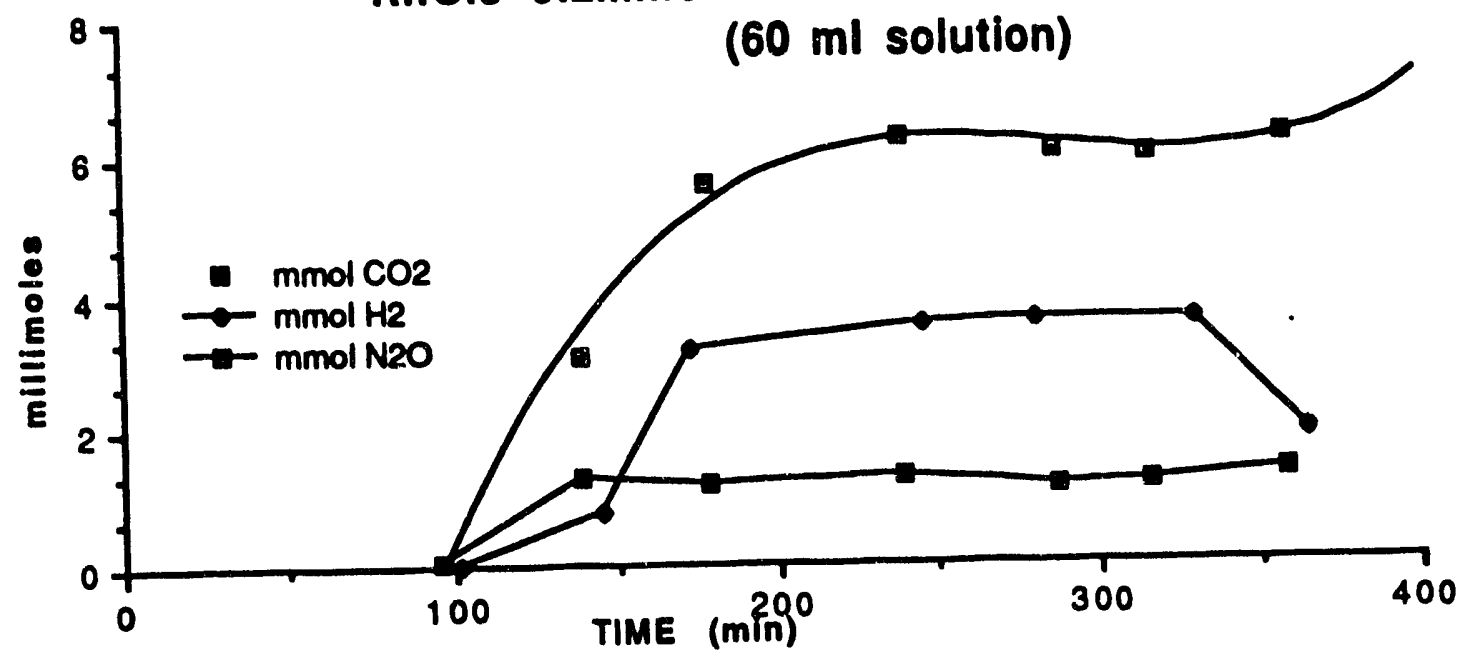

Turnover number $\approx 315$ moles $\mathrm{H}_{2} /$ mole $\mathrm{Rh} /$ day based on the two points at 101 and 173 mins. 


\section{TECHNICAL REPORT}

to the

Wescinghouse Savannah River Laboratory

Aiken, South Carolina

on

\section{ELUCIDATION OF NOBLE METAL/FORMIC ACID CHEMISTRY DURING DWPF FEED PREPARATION \\ by}

R. B. King, Regents' Professor and Principal Investigator

A. D. King, Jr., Professor and Faculty Associate

N. K. Bhattacharyya, Post-Doctoral Fellow

L. Colletti, Graduate Student

G. Vemparala, Graduate Student

V. Vemparala, Graduate Student

Report 6

August, 1991

Abstract. Currently available information suggests that the rhodium-catalyzed decomposition of formic acid to give hydrogen can be interpreted as a heterogeneous process in which the catalytically active species consists of small particles of thodium metal which lose their activity upon aggregation. Such information includes studies on ideal $\mathrm{NaNO}_{2} / \mathrm{RhCl}_{3} / \mathrm{HCO}_{2} \mathrm{H}$ systems at $-95^{\circ} \mathrm{C}$ and $\mathrm{NO}_{2} / \mathrm{Rh}$ ratios in the $1-100$ range as well as studies on the rhodium-catalyzed decomposition of formic acid in $\mathrm{pH}=12$ low-nitrite Purex sludge simulant in the $95-100^{\circ} \mathrm{C}$ temperature range.

The reduction of nitrite and nitrate with formic acid at $\mathrm{pH} 3.5 \mathrm{has}$ also been studied. In this $\mathrm{pH}$ range nitrate has been found to be unreactive towards formic acid whereas nitrite undergoes both disproportionation into nitrate and nitric oxide as well as reduction to nitrous oxide. This suggests that treatment of sludge simulant containing nitrite with formic acid can lead to buildup of nitrate ion during processing with the possibility of correlating nitrate formation with nitric oxide production. 


\section{Homogeneous Versus Heterogeneous Catalysis?}

We have been assuming that the rhodium-catalyzed decomposition of formic acid to give hydrogen in the presence of nitrite, which we described in previous technical reports, 1.2 is a homogeneous process catalyzed by nitrorhodium complexes. Thus thodium trichloride was reported more than a century ago ${ }^{3}$ to react with excess nitrite ion in boiling water to give salts of the hexanitrorhodate ion, $\left[\mathrm{Rh}\left(\mathrm{NO}_{2}\right)_{6}\right]^{3-}$. Three of the six nitro groups in the hexanitrorhodate ion are reported to be labile upon treatment with strong oxidants $^{4}$ or amidosulfuric acid 5 indicating the feasibility of opening up catalytic sites on the central rhodium atom under the conditions of formic acid decomposition. We now question this interpretation of our experimental observations and suggest that the rhodiumcatalyzed decomposition of formic acid to give hydrogen in the presence of nitrite might actually be a heterogeneous process involving small thodium metal clusters formed in the reduction of rhodium(III) precursors with the formic acid substrate. The system appears to be catalytically active only when rhodium metal is initially formed in the reduction of rhodium(III). Furthermore, the rhodium catalyst becomes inactive when the initially produced small clusters of rhodium atoms aggregate to form larger units. This aggregation process appears to be retarded in the presence of a sclid matrix such as the insoluble metal oxides present in the DWPF sludge simulants. Rhodium, like all other platinum metals, has long been known to be an active heterogeneous catalyst for the decomposition of formic acid to carbon monoxide and hydrogen at $100^{\circ} \mathrm{C} .6$

The following experimental observations, many of which are described in this report, suggest heterogeneous rather than homogeneous catalysis of the hodium-catalyzed decomposition of formic acid:

1. The $\mathrm{RhCl}_{3} \mathrm{NaNO}_{2}$ "ideal" catalyst system for the decomposition of formic acid to carbon dioxide and hydrogen has a much shorter lifetime, at least at $\mathrm{pH} \sim 2$, than the rhodium catalyst in nitrite-containing DWPF sludge simulants. Furthermore, the "bursts" of hydrogen production with this "ideal" catalyst system occur exactly when the originally

\footnotetext{
'Technical Report 4 to WSRL on Elucidation of Noble MetalFormic Acid Chemistry during DWPF Feed Preparation prepared June 1991.

2Technical Report 5 to WSRL on Elucidation of Noble MetaVFormic Acid Chemistry during DWPF Feed Preparation prepared July 1991.

${ }^{3}$ Leidié, E., Compt. Rend., 1890, 111, 106.

${ }^{4}$ Kukushkin, Yu. N.; Stoianova, O. V., Russ. J. Inorg. Chem., 1977, 22. 1844.

${ }^{5}$ Mel'chakova, N. V.; Ozerova, G. P.; Peshkova, V. M., Russ. J. Inorg. Chem., 1967, 12, 577.

6Müller, E.; Loofpabel, W., Monatshefte für Chemie, 1929, 53, 825.
} 
orange thodium(III) solution begins to turn gray indicating incipient reduction to rhodium metal.

2. The thodium-catalyzed decomposition of formic acid in the DWPF sludge simulants exhibits poorly reproducible behavior, particularly with regard to induction periods before hydrogen production, suggestive of the role of the solid metal oxide particles in the sludge simulants. Random inhomogeneities in the metal oxide particle sizes upon sampling the sludge simulant could lead to variation in behavior owing to widely varying stabilities of the small aggregates of thodium atoms needed for catalytic activity.

If this interpretation of the rhodium-catalyzed formic acid decomposition to hydrogen as a heterogeneous rather than a homogeneous process is correct, then measured tumover numbers as a function of the concentrations of rhodium, nitrite, $\mathrm{pH}$, etc. have relatively little fundamental significance because of the variability in paricle sizes and thereiore surface areas of the solid particles involved in the catalytic process including both thodium metal and the metal oxides in the sludge simulant. Nevertheless, such information is still necessary in connection with anticipating the amounts of hydrogen generation in the operation of the DWPF plant.

The interpretation of the rhodium-catalyzed decomposition of formic acid to carbon dioxide and hydrogen in the presence of nitrite ion as a heterogeneous process based on small particles of thodium metal suggests the following experiments which are planned for the near future:

1. Catalysis of formic acid decomposition in "ideal" $\mathrm{RhCl} / 3 / \mathrm{NaNO}_{2}$ systems will be studied in which alumina has been added in amounts approximating the total insoluble metal oxides in the sludge simulant. In such systems the surface of the alumina should stabilize the small rhodium metal particles formed in the formic acid reduction of thodium(III) leading to longer catalyst lifetimes.

2. The promotion of the catalytic activity of thodium by the presence of nitrite need not depend upon any specific complexing ability of the nitrite to form nitrorhodium complexes. Instead, the presence of any anion in sufficient quantities might inhibit aggregation of the small thodium metal particles to form larger catalytically inactive units. We therefore. plan to investigate the effects of substituting other simple anions such as fluoride, chloride, nitrate, sulfate, and/or methanesulfonate for nitrite in the rhodium catalyst system. The correlation between catalytic activity and complexing ability of the added anions will be of interest.

The interpretation of the rhodium-catalyzed decomposition of formic acid to carton dioxide and hydrogen in the presence of nitrite ion as a heterogeneous process has the following implications conceming inhibition of unwanted hydrogen generation: 
1. The inhibition of hydrogen generation by strong complexing agents such as ethylenediamine tetraacetic acid (EDTA) is consistent with heterogeneous as well as homogeneous catalysis since complexation of rhodium with a sufficiently strong complexing agent appears to inhibit its reduction. Therefore approaches to the inhibition of hydrogen generation by finding suitable strong complexing agents favoring binding to rhodium as much as possible are still valid.

2. An alternative approach to the inhibition of hydrogen generation might be based on finding an agent which can accelerate the aggregation of the initially formed thodium metal particles to catalytically inactive aggregates.

\section{New Experimental Results}

\section{A. Experiments with Sludge Simulants (N. K. Bhattacharyya and V. Vemparala)}

We have experienced some difficulties in getting reproducible results with the $\mathrm{pH}=$ 12.0 low nitrite Purex sludge simulant. A new bottle of this sludge simulant was therefore opened on July 31, 1991, and used for further studies on formic acid decomposition catalyzed by thodium in order to assess in a more controlled manner any "aging" effects of the sludge on the formic acid decomposition reaction. The runs used the experimental conditions described in previous technical reports with $38.5 \mathrm{~mL}$ of the sludge, $2.1 \mathrm{~mL}$ of $88 \%$ formic acid, and 0.2 mmoles of hydrated thodium trichloride. The results are summarized in Table 1 and depicted in Figure 1.

The results indicated in Table 1 and Figure 1 suggest some problems with reproducibility with freshly opened bottles of sludge simulant suggesting some changes in the sludge simulant after opening by slow reactions. In order to speed up any possible air oxidation reactions, the sludge was aerated in the nine-day experiment, which reproduced within experimental errors the experiment with eight-day old sludge in both turnover

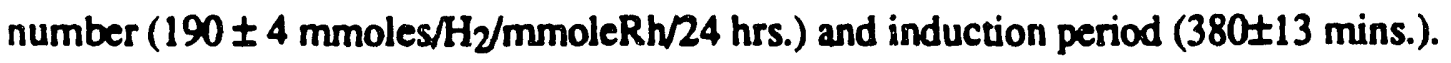

Some experiments were performed at $99-100^{\circ}$ using the $\mathrm{pH}=12.0$ low nitrite IDMS sludge simulant and smaller rhodium concentrations ( -0.05 mmoles $R h)$. In onder to obtain these higher temperatures a bath of white mineral oil was used to heat the reaction vessel. The setting on the hot plate heating the oil bath was first calibrated in order to keep the temperature fluctuations in the $\pm 1^{\circ} \mathrm{C}$ range. The results are given in Table 2. 
Table 1

\begin{tabular}{ccccc}
\hline $\begin{array}{c}\text { Time in days } \\
\text { (since opening } \\
\text { the botrle) }\end{array}$ & $\begin{array}{c}\text { Temperature } \\
\text { C }\end{array}$ & $\begin{array}{c}\text { Tumover } \\
\text { Number } \\
\text { (no. of points) }\end{array}$ & $\begin{array}{c}\text { Induction } \\
\text { Period in } \\
\text { Minutes }\end{array}$ & $\begin{array}{c}\text { pH at end of } \\
\text { experiment }\end{array}$ \\
\hline 1 & $87 \pm 1$ & $810(2)$ & 80 & 6.03 \\
6 & $92 \pm 2$ & $150(3)$ & 22 & 6.25 \\
7 & $87 \pm 2$ & $170(4)$ & 210 & $64(3)$ \\
8 & $92 \pm 2$ & $186(3)$ & 193 & 6.1 \\
$\begin{array}{c}8 \text { (after } \\
\text { bubbling air for }\end{array}$ & $92 \pm 2$ & $193(8)$ & 367 & 6.29 \\
2 hr. through \\
sludge)
\end{tabular}

Figure 1

Experimente with the bottle of $\mathrm{pH}=12.0$ low nitrite Purex Sludge opened 7/31/91 $38.5 \mathrm{~mL}$ sludge, $2.1 \mathrm{~mL} 88 \%$ formic ecid, 0.2 mmoles hydrated rhodium irlehloride

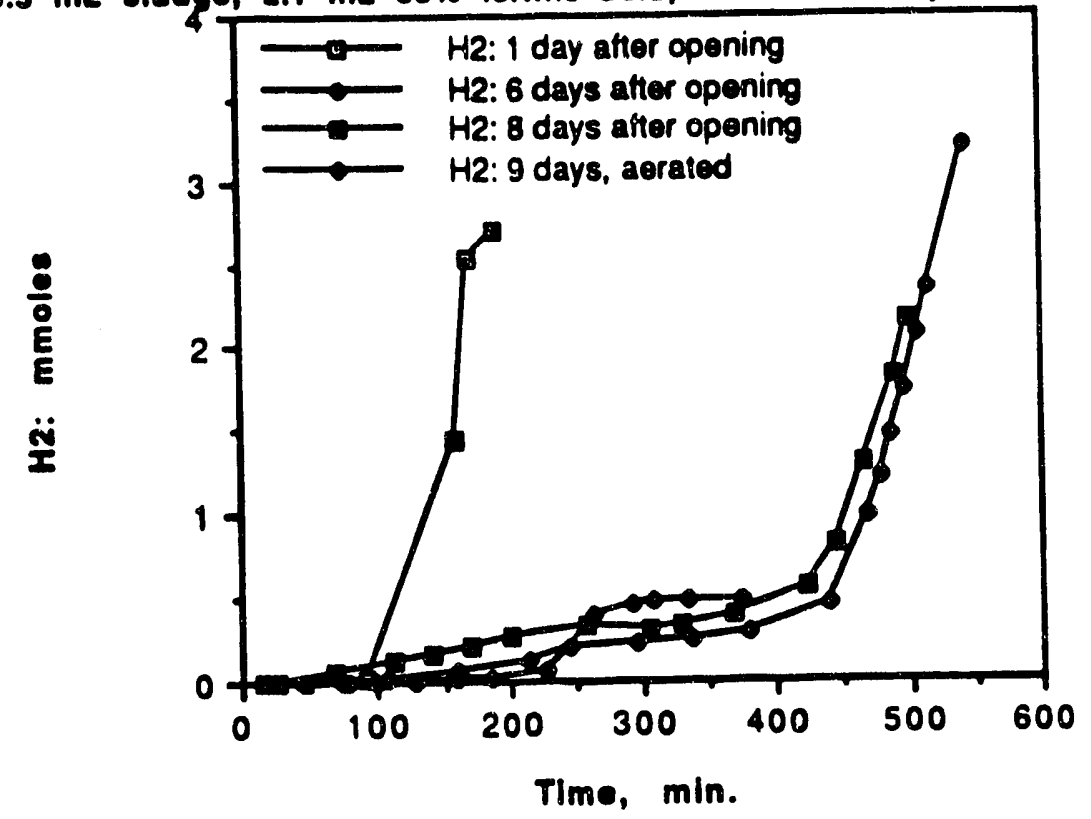

Table 2

$\mathrm{RhCl}_{3}$ (mmoles) Temp. $\left(^{\circ} \mathrm{C}\right.$ Induction Period Tumover perday Final $\mathrm{pH}$

$\begin{array}{ccccc}0.058 & 99-100 & 101 \mathrm{~min} \text {.(first) } & 28 & 6.4 \\ & & 260 \mathrm{~min} \text {. (second) } & 38 & \end{array}$


The hydrogen evolution data from these experiments are plotted in Figure 2. The following observations are of interest:

1. The induction periods and turnover numbers appear to be rather erratic at these low rhodium concentrations. An experiment at an even lower thodium concentration currently in progress appears not to give any hydrogen at all.

2. Two bursts of hydrogen evolution are observed in the first experiment using 0.058 mmoles of thodium.

The erratic nature of these results is suggestive of a heterogeneous rather than a homogeneous catalytic process where the particle size and surface area of the insoluble oxides are critical factors determining the catalytic activity.

Figure 2

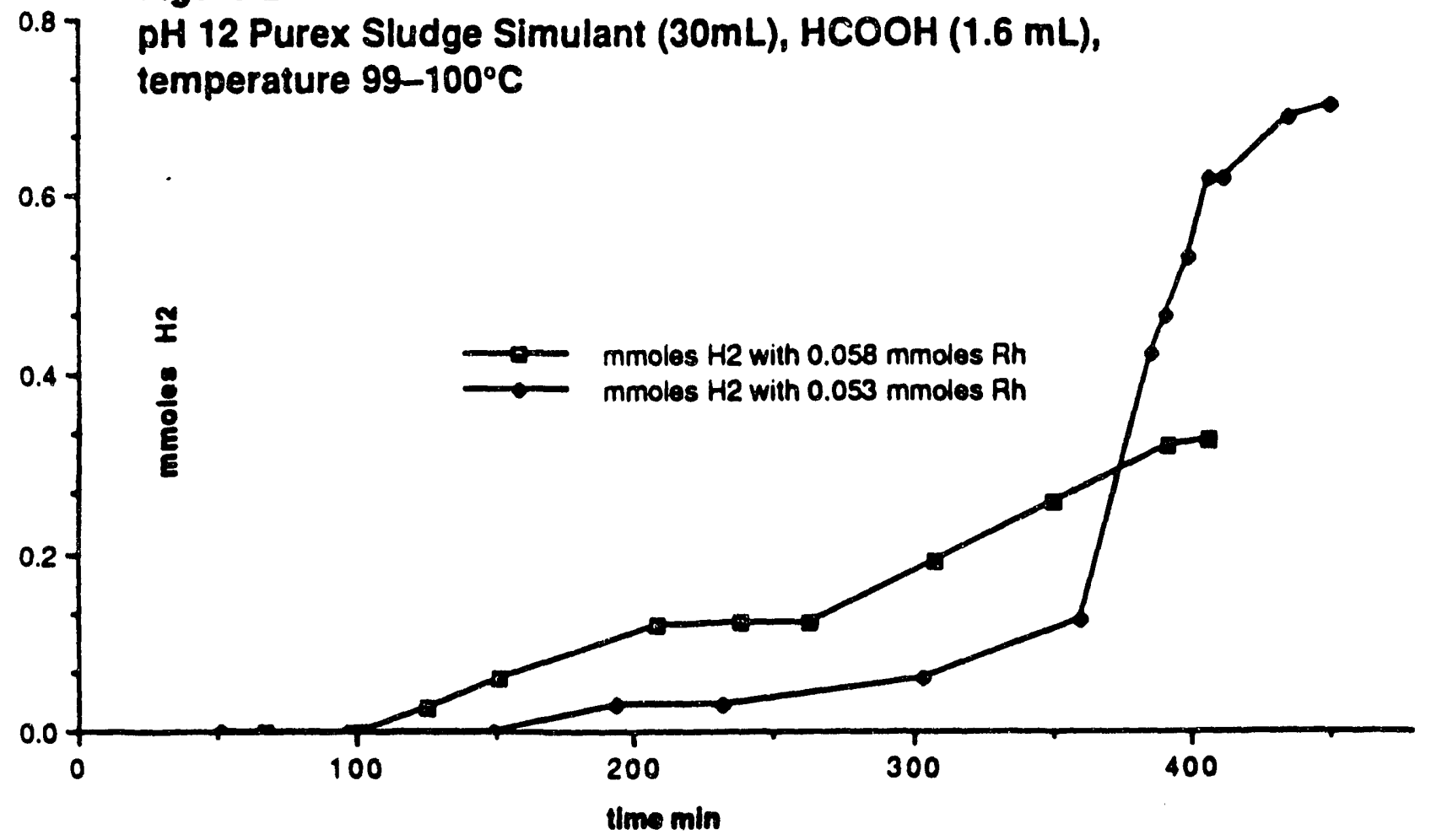

Finally, it has been of some concem to us that $\mathrm{CO}_{2}$ loss on heating from a mixture of authentic sludge simulant (Purex $\mathrm{pH}=12$ ) and formic acid will lead to a significant rise in $\mathrm{pH}$ in the early stages of a digestion reaction. This, however, is not the case. A sample containing $38.5 \mathrm{~mL}$ of sludge simulant with $2.1 \mathrm{~mL} 88 \%$ formic acid (initial $\mathrm{pH}=3.5$ ) was heated at $94^{\circ} \mathrm{C}$ in an open container for $2 \mathrm{hrs}$. corresponding to the time encompassing all of the $\mathrm{CO}_{2}$ evolution observed in the sludge simulant experiments. The container was then 
sealed and allowed to cool to room temperature. The $\mathrm{pH}$ was then measured and found to be -4.0 . This indicates that the intrinsic buffering capacity of the formic acid/formate and the other components in the sludge simulant prevented any major rise in the $\mathrm{pH}$. As might be expected, this $\mathrm{pH}$ is identical to that found at the end of digestion reactions for which no hydrogen production is observed.

B. Hydrogen evolution studies in a pure $\mathrm{HCO}_{2} \mathrm{H} / \mathrm{RhCl}_{3} / \mathrm{NaNO}_{2}$ system (L. Colletti):

A reaction vessel with a volume of $286 \mathrm{~mL}$ was charged with $38.5 \mathrm{~mL}$ of water, $1.5 \mathrm{~mL}$ of $88 \%$ formic acid, 0.1 mmoles of $\mathrm{RhCl}_{3}$, and $\mathrm{NaNO}_{2}$ to give $\mathrm{NO}_{2}-/ \mathrm{Rh}$ ratios of $1,2,3,4,6,10,20$, and 100 . The reaction mixtures were flushed with argon gas and then heated to $94^{\circ} \mathrm{C}$. The original red-orange color changed to black as the reaction took place suggestive of reduction to thodium metal. The off-gases were sampled by gas chromatography and analyzed in the usual manner. The $\mathrm{pH}$ was measured at both the beginning and the end of the experiment.

The results from these experiments are listed in Table 3. However, turnover number information from such experiments appeared to be kinetically questionable since the reactions took place over a short period ( $-5 \mathrm{~min}$.) relative to the analyses so that three or more data points could not taken during the period of hydrogen evolution and the reaction appeared to start before the final temperature was reached. In an attempt to minimize this problem an experiment was done using 0.077 mmoles $\mathrm{RhCl}_{3}$ and $0.311 \mathrm{mmoles} \mathrm{NaNO}_{2}$ (NO/ $/ \mathrm{Rh}$ ratio $=4 / 1)$ in which the formic acid was added only after the mixture reached the desired reaction temperature. Thus the mixture of $\mathrm{RhCl}_{3}$ and $\mathrm{NaNO}_{2}$ in a total of $38.5 \mathrm{~mL}$ of water was heated to a constant temperature of $96 \pm 2^{\circ} \mathrm{C}$. At this temperature $1.5 \mathrm{~mL}$ of degassed $88 \%$ formic acid was added. Again the off-gases were sampled by gas chromatography and analyzed and the $\mathrm{pH}$ was measured at the end of the experiment.

In the first set of experiments a color change from a clear orange to a fine suspension of black particles was observed. This color change is probably due to the reduction of rhodium(III) to metallic rhodium. This color change occurred in the temperaure range $75-90^{\circ} \mathrm{C}$ over a period of less than 5 minutes.

In the second experiment in which the formic acid was added only at $96^{\circ} \mathrm{C}$ the color change was significantly different. At room temperature with no added heat or formic acid the solution was a clear orange but upon heating became totally colorless. A possible explanation for this color change is the formation of $\left[\mathrm{Rh}\left(\mathrm{NO}_{2}\right)_{6}\right]^{3-}$ in solution which is reported ${ }^{3}$ to be colorless. When the formic acid was added, the colorless solution became 
In either set of these experiments evolution of all of the $\mathrm{H}_{2}$ and $\mathrm{N}_{2} \mathrm{O}$ and most of the $\mathrm{CO}_{2}$ is produced at the time the color is changing from orange to black, usually in a "burst," which has made it very difficult to get meaningful kinetic data from these experiments. In the experiments in which the $\mathrm{NO}_{2}-/ \mathrm{Rh}$ ratios were $3,4,6$, and 10 the black precipitate remained suspended for $\sim \mathbf{4 8} \mathrm{hr}$. before settling. In the experiments in which the $\mathrm{NO}_{2}-/ \mathrm{Rh}$ ratios were $1,2,20$, and 100 the black precipitate "clumped" together during the reactions. This suggests that a paricular range of $\mathrm{NO}_{2}-/ \mathrm{Rh}$ ratios is needed to keep the precipitate in suspension and that a too high or a too low $\mathrm{NO}_{2}-/ \mathrm{Rh}$ ratio will cause clumping. These observations are suggestive of heterogeneous catalysis by finely divided thodium metal which becomes catalytically inactive as the particle size becomes too large.

\section{Table 3}

Hydrogen Evolution Studies in a Pure $\mathrm{HCO}_{2} \mathrm{H} / \mathrm{RhCl}_{3} / \mathrm{NaNO}_{2}$ System $\mathrm{H}_{2}$ turnover mmoles $\mathrm{H}_{2} /$ mmoles

[NO2laRh]

1

2

3

4

6

10

20

100
$\mathrm{Bh} / 24 \mathrm{hr}$

61

123

116

313

153

262

351

553
Staringed

Einishine oH

2.0

2.0

2.0

2.0

2.0

2.1

2.0

2.1

2.1

2.2

2.4 
C. Studies on nitrogen oxide evolution upon reaction of nitrite with formic acid under the conditions of the IDMS sludge simulants (G. Vemparala)

This work is part of an ongoing study in which a sludge suspension is constructed starting with the most rudimentary components, namely water and formic acid/formate, i.e., a formic acid/formate buffer (1.57 acid/salt ratio) having a $\mathrm{pH}$ of 3.5 . We have nearly completed a series of studies to study the fate of nitrite ion and its reduction to the nitrogen oxide off-gases produced in the early stages of sludge digestion. Although several nitrite concentrations have been examined, the two sets of results shown here represent nitrite containing systems modelled after high nitrite sludge.

Figure 3 shows the gases produced by a formic acid/formate buffer $(\mathrm{pH}=3.5)$ containing sodium nitrite at an appropriate concentration to mimic high nitrite sludge. It is seen that the principal nitrogen containing gas is $\mathrm{N}_{2} \mathrm{O}$ although a smaller amount of $\mathrm{NO}$ is produced as well. After the reaction has reached completion, 1.5 mmoles NO, 4.1 mmoles $\mathrm{N}_{2} \mathrm{O}$, and -6 mmoles $\mathrm{CO}_{2}$ are seen to have been produced at $92^{\circ} \mathrm{C}$. The $\mathrm{N}_{2} \mathrm{O}$ can arise from the reduction of nitrite with formic acid acconding to the following equation:

$$
2 \mathrm{NO}_{2}^{-}+2 \mathrm{HCO}_{2} \mathrm{H}+2 \mathrm{H}^{+} \longrightarrow \mathrm{N}_{2} \mathrm{O}+3 \mathrm{H}_{2} \mathrm{O}+2 \mathrm{CO}_{2}
$$

Figure 4 shows the results of an experiment carried out under virtually identical conditions with one exception: the formic acid/formate buffer has been replaced by an acetic acid/acetate buffer having the same $\mathrm{pH}$ but lacking any reducing capabilities. Here one sees that only NO is produced, reflecting the role of the nitrite disproportionation reaction cocurring at $94^{\circ} \mathrm{C}$ and $\mathrm{pH}=3.5$ according to the following equation:

$$
2 \mathrm{H}^{+}+3 \mathrm{NO}_{2}-\longrightarrow \mathrm{NO}_{3}^{-}+2 \mathrm{NO}+\mathrm{H}_{2} \mathrm{O}
$$

Experiments with different concentrations of nitrite ion all give results consistent with Figures 3 and 4.

- When combined, the results of Figures 3 and 4 suggest that the NO off-gas observed at early stages of the formate digestion reaction results from the disproportionation of $\mathrm{NO}_{2}$ - rather than reduction by formic acid while $\mathrm{N}_{2} \mathrm{O}$ constitutes the reduction product of the nitrite/formic acid reaction. 
Figure 3

HCOOH (49.4 mmoles)NHCOONa (31.5 mmolea)NaNO2 (17.9 mmoles)

$60 \mathrm{~mL}$ solution, Temperature $92 \pm 2^{\circ}$

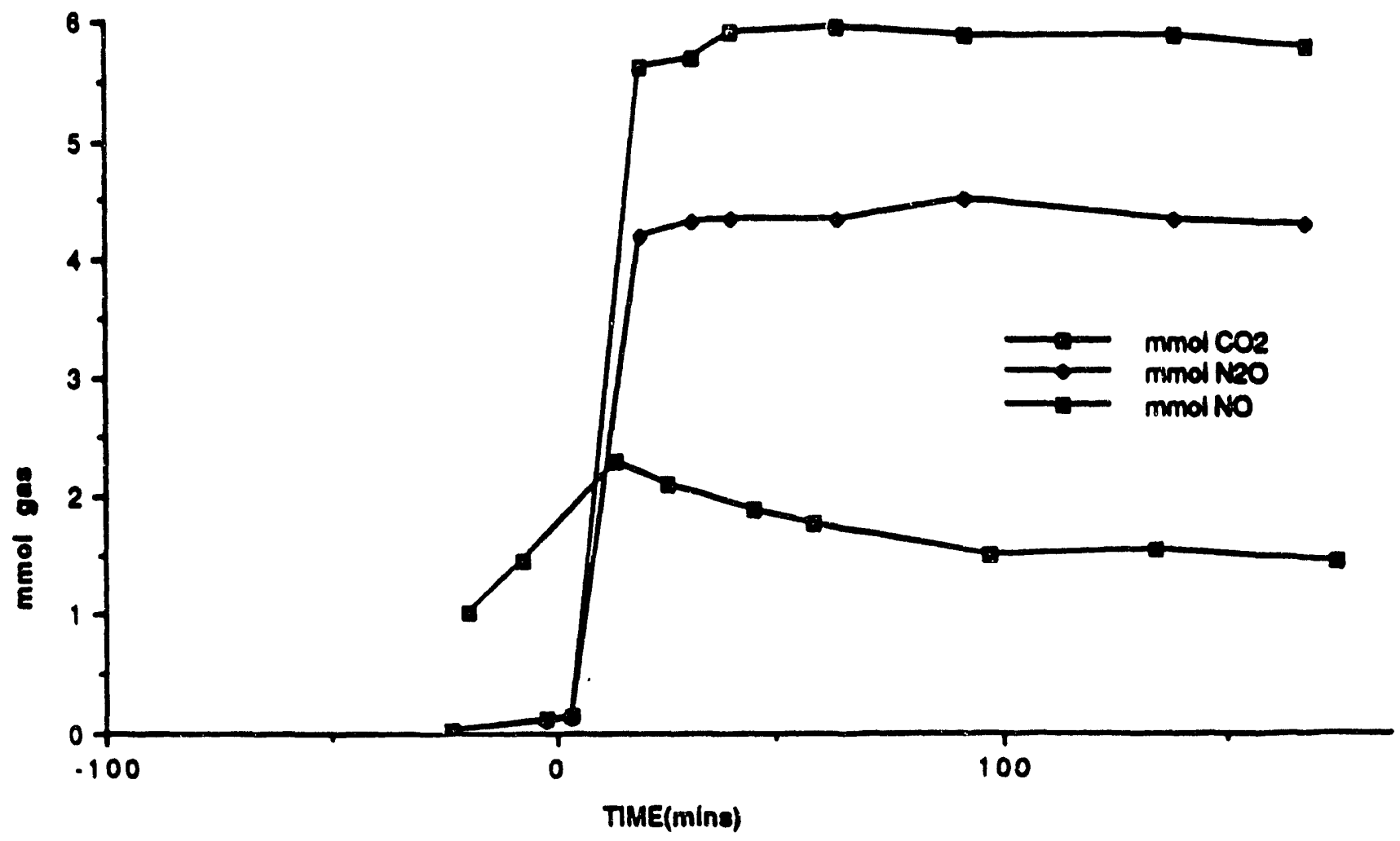

Figure 5 shows the production of hydrogen, $\mathrm{N}_{2} \mathrm{O}$, and $\mathrm{NO}$ which are produced when Purex $(\mathrm{pH}=12)$ sludge simulant reconstituted with sodium nitrite to model the high nitrite sludge is treated with formic acid at $91^{\circ} \mathrm{C}$. Here it is seen that the relative amounts of $\mathrm{NO}$ and $\mathrm{N}_{2} \mathrm{O}$ produced by the digestion are reversed from that seen in Figure 3 suggesting that nitrite disproportionation has taken precedence over reduction in the presence of real sludge simulant.

Since the high concentrations of NO produced in these reactions can be attributed to disproportionation (equation 2), one consequence of the data shown in Figure 5 is that high concentrations of nitrate ion are produced in the early stages of the high nitrite sludge digestion reaction. Thus in the absence of reactions leading to the degradation of $\mathrm{NO}_{3}$-, high concentrations of $\mathrm{NO}_{3}-$ are presence at the onset of hydrogen production. It is of interest, therefore, to see if $\mathrm{NO}_{3}$ - is reduced by formic acid under the conditions present in the beginning of a typical digestion reaction. With this in mind, two experiments were carried out with solutions composed of the usual formic acid/formate buffer ( $\mathrm{pH}=3.5, \mathrm{~T}=$ $92^{\circ} \mathrm{C}$ ) with added $\mathrm{NaNO}_{3}$. These systems produced absolutely no gaseous products $\left(\mathrm{CO}_{2}\right.$ 
or nitrogen oxides) indicating that nitrate ion is not reduced by formic acid at $\mathrm{pH}=3.5$ and $92^{\circ} \mathrm{C}$.

Holtze et al. ${ }^{7}$ note that the reduction reactions involving formic acid and nitric acid at low to moderate concentrations needed to be "...initiated by adding a small quantity of $\mathrm{NaNO}_{2}$." We have carried out two experiments in onder to see if nitrite ion initiates the reduction of nitrite ion by formic acid under the conditions of a formic acid digestion ( $\mathrm{pH}$ 3.5. $\mathrm{T}=94^{\circ} \mathrm{C}$ ). In these two experiments 0.85 mmoles and 6.9 mmoles of $\mathrm{NaNO}_{2}$ were added to a solution containing 6.9 mmoles of $\mathrm{NaNO}_{3}$ dissolved in $60 \mathrm{~mL}$ of a buffered (pH - 3.5) formic acid/fonnate solution each containing 49.4 mmoles formic acid and 31.5 mmoles formate. In both cases the $\mathrm{NO}$ and the gaseous reduction products, $\mathrm{N}_{2} \mathrm{O}$ and $\mathrm{CO}_{2}$, could be quantitatively accounted for by simultaneous disproportionation and reduction reactions of the nitrite ion in the mixture with no evidence being found for any reaction of $\mathrm{NO}_{3}$ - whatsoever.

We are currenuly examining how the relative rates of disproportionation (producing NO) versus reduction by formic acid (producing $\mathrm{N}_{2} \mathrm{O}$ ) are affected by formic acid under the usual conditions $\left(\mathrm{pH}=3.5, \mathrm{~T}=94^{\circ} \mathrm{C}\right.$ ). The experiments are nearly complete and indicate that the $\mathrm{NO} / \mathrm{N}_{2} \mathrm{O}$ ratios observed under experimental conditions with real sludge simulant can be closely approximated in our model system at low formic acid concentrations. Further information is expected to be available by the time of the next repor.

7Holze, K.; Finke, H.-D.; Kelm, M.; Deckwer, W.-D., Ger. Chem. Eng., 1979, 2, 361. 
Eigure 4

CH3COOH(110.4 mmols)/ CH3COONa (6 mmols)/ NaNO2(17.9 mmols), $60 \mathrm{~mL}$ soln. Temperature : $94 \pm 1^{\prime}$

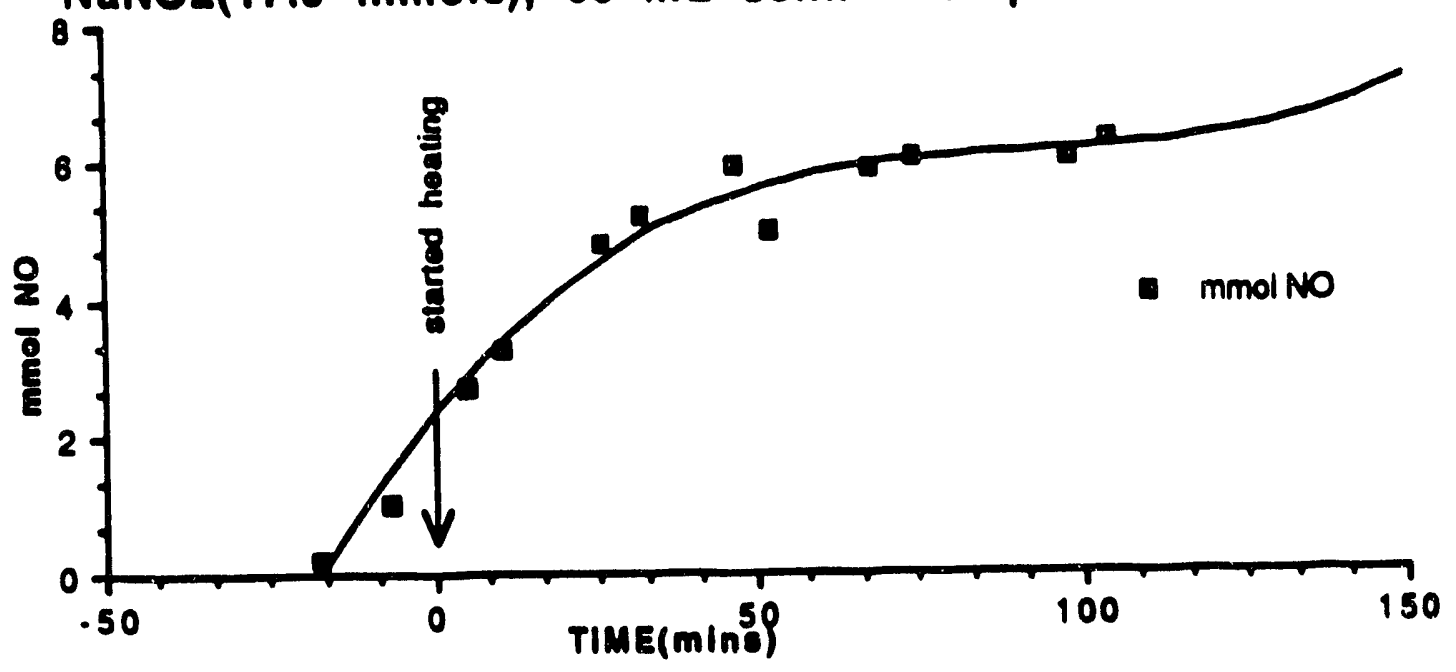

Figure 5

Bottle \#1 pH 12 Sludge $(38.5 \mathrm{~mL})$, HCOOH $(2.1 \mathrm{~mL})$,

NaNO2 (9.1 mmols), RhCl3 (0.2 mmols), temperature $91 \pm 2^{\circ} \mathrm{C}$

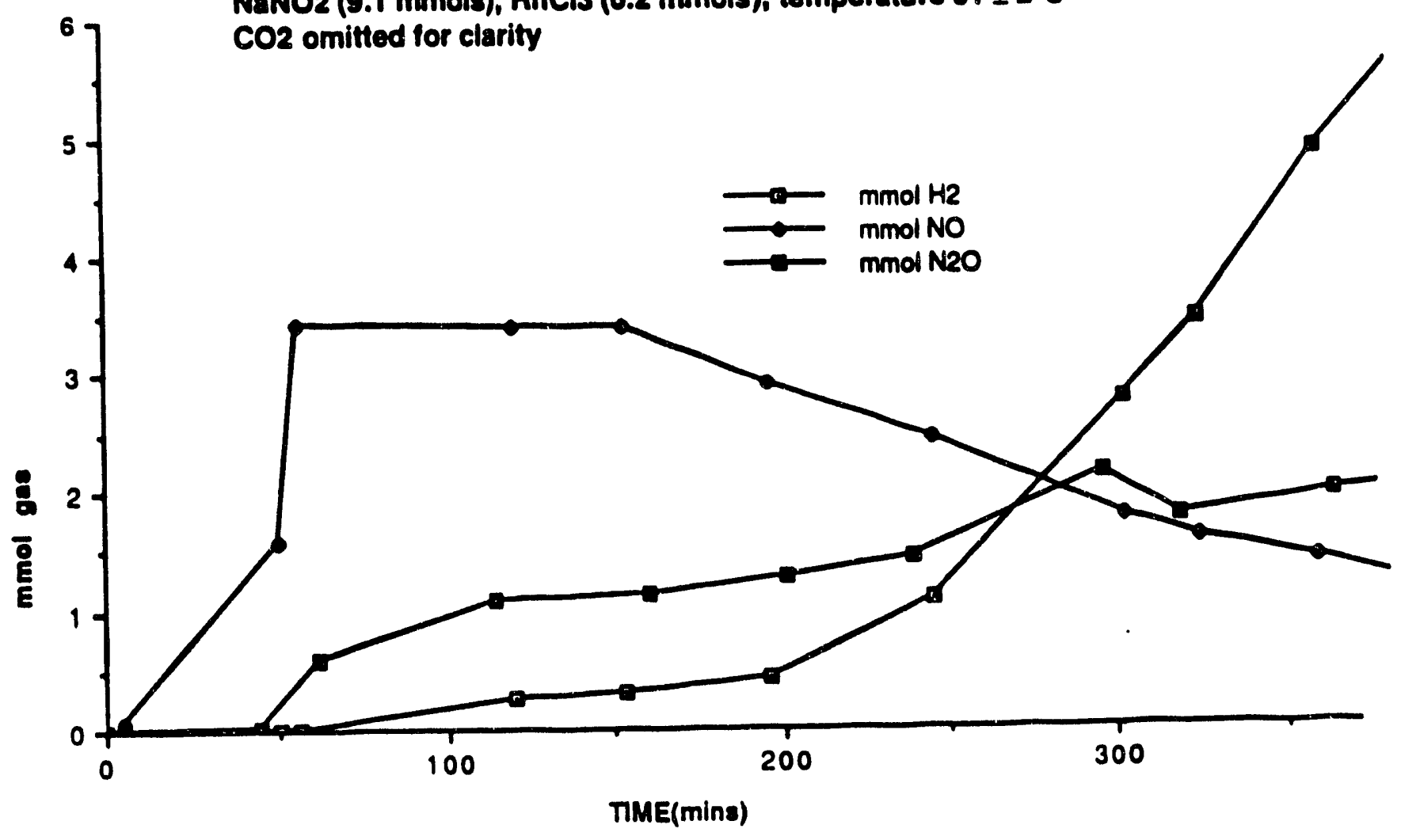




\section{TECHNICAL REPORT}

to the

Westinghouse Savannah River Laboratory

Aiken, South Carolina

on

\section{ELUCIDATION OF NOBLE METAL/FORMIC ACID CHEMISTRY DURING DWPF FEED PREPARATION}

by

R. B. King, Regents' Professor and Principal Investigator

A. D. King, Jr., Professor and Faculty Associate

N. K. Bhattacharyya, Post-Doctoral Fellow

L. Colletti, Graduate Studeni

G. Vemparala, Graduate Student

V. Vemparala, Graduate Student

\section{Report 7}

September, 1991

The September, 1991 report (Technical Report 7) was presented orally to TNX at the Savannah River Laboratory on October 3. Copies of the transparencies used are appended to this report.

Of particular interest was the observation that nitrilotriacetic acid, $\mathrm{N}\left(\mathrm{CH}_{2} \mathrm{CO}_{2} \mathrm{H}\right)_{3}$, NTA, appeared to be more effective than EDTA, $\left(\mathrm{HCO}_{2} \mathrm{CH}_{2}\right)_{2} \mathrm{NCH}_{2} \mathrm{CH}_{2} \mathrm{~N}\left(\mathrm{CH}_{2} \mathrm{CO}_{2} \mathrm{H}\right)_{2}$, at inhibiting the rhodium-catalyzed formic acid decomposition in low nitrite Purex sludges. This observation has been followed up since the October 3 presentation and further details will be presented in Technical Report 8. 


\section{ELUCIDATION OF \\ NOBLE METAL/FORMIC ACID \\ CHEMISTRY DURING DWPF FEED PREPARATION}

by

R. B. King, Regent's Professor

A. D. King, Jr. Professor

N. K. Bhattacharyya, Post-doctoral Fellow

L. P. Colletti, Graduate Student

G. Vemparala, Graduate Student

V. Vemparala, Graduate Student

Department of Chemistry

University of Georgia

Athens, Georgia 30602

Review for TNX at the Westinghouse Savannah River

Laboratory

October 3, 1991

Aiken, South Carolina 


\section{OBJECTIVES OF RESEARCH PROJECT}

- Evaluation of sludge simulants as media for hydrogen generation from formic acid

- Evaluation of the role of noble metals, particularly $\mathrm{Ru}, \mathrm{Rh}, \mathrm{Pd}, \mathrm{Ag}$, as key components in hydrogen generation catalyst systems

- Determination of other parameters affecting rate of hydrogen production from formic acid

- Development of methods for the inhibition of hydrogen generation from formic acid

- Determination of the homogeneous versus heterogeneous nature of the catalytic reaction

- Development of a kinetic model for the catalytic reaction

- Reconstruction of sludge simulants by components 


\section{REACTIONS OF FORMIC ACID WITH METALS OF SIGNIFICANCE IN THE SRS PROCESS}

- Formic Acid Decomposition $\mathrm{HCO}_{2} \mathrm{H} \longrightarrow \mathrm{H}_{2}+\mathrm{CO}_{2}$

- Formic Acid Dehydration $\mathrm{HCO}_{2} \mathrm{H} \longrightarrow \mathrm{H}_{2} \mathrm{O}+\mathrm{CO}$

- Reduction of Metals with Formic Acid $\mathrm{Mn+}+\mathrm{HCO}_{2} \mathrm{H} \longrightarrow \mathrm{M}(n-2)++2 \mathrm{H}++\mathrm{CO}_{2}$

- Formic Acid Oxidation

$2 \mathrm{HCO}_{2} \mathrm{H}+\mathrm{O}_{2} \longrightarrow 2 \mathrm{H}_{2} \mathrm{O}+2 \mathrm{CO}_{2}$ 
Composition of the HM and Purex Sludge Simulants Used in this Work

High Nitrite $\mathrm{pH}=11$ HM Sludge
Low Nitrite Purex $(\mathrm{pH}=12)$ Sludge
Differences in Major Components Amount, \% by weight Amount, \% by weight

\begin{tabular}{|c|c|c|c|}
\hline $\mathrm{Al}(\mathrm{OH})_{3}$ & 25.031 & 12.298 & $2 / 1$ \\
\hline $\mathrm{BaSO}_{4}$ & 0.219 & 0.505 & \\
\hline $\mathrm{Cs}_{3}\left(\mathrm{PO}_{4}\right)_{2}$ & 0.097 & 0.254 & \\
\hline $\mathrm{CaCO}_{3}$ & 1.478 & 5.148 & \\
\hline $\mathrm{CaSO}_{4}$ & 0.000 & 0.468 & \\
\hline $\mathrm{Cr}_{2} \mathrm{O}_{3}$ & 0.220 & 0.409 & \\
\hline $\mathrm{CsNO}_{3}$ & 0.028 & 0.003 & \\
\hline $\mathrm{CuO}$ & 0.054 & 0.182 & \\
\hline $\mathrm{Fe}(\mathrm{OH})_{3}$ & 25.893 & 51.204 & Redox, $-1 / 2$ \\
\hline $\mathrm{Nd}_{2} \mathrm{O}_{3}$ & 2.342 & 0.253 & \\
\hline KOH & 0.170 & 0.397 & \\
\hline $\mathrm{MgO}$ & 0.342 & 0.246 & • \\
\hline $\mathrm{MnO}_{2}$ & 6.650 & 7.320 & Redox \\
\hline $\mathrm{Na}_{2} \mathrm{CO}_{3}$ & 0.107 & 0.148 & \\
\hline $\mathrm{Na}_{2} \mathrm{SO}_{4}$ & 0.471 & 0.169 & \\
\hline $\mathrm{Na}_{3} \mathrm{PO}_{4}$ & 0.041 & 0.012 & \\
\hline $\mathrm{NaCl}$ & 0.476 & 1.545 & \\
\hline $\mathrm{NaF}$ & 0.259 & 0.275 & \\
\hline $\mathrm{NaI}$ & 0.000 & 0.027 & \\
\hline $\mathrm{NaNO}_{2}$ & 12.083 & 2.455 & $-5 / 1$ \\
\hline $\mathrm{NaNO}_{3}$ & 0.478 & 0.358 & \\
\hline $\mathrm{NaOH}$ & 1.367 & 3.507 & \\
\hline $\mathrm{Ni}(\mathrm{OH})_{2}$ & 1.308 & 4.507 & \\
\hline $\mathrm{PbSO}_{4}$ & 0.220 & 0.505 & \\
\hline $\mathrm{SeO}_{2}$ & 0.002 & 0.003 & \\
\hline $\mathrm{SiO}_{2}$ & 5.039 & 1.672 & \\
\hline $\mathrm{SrCO}_{3}$ & 0.408 & 0.038 & \\
\hline $\mathrm{TeO}_{2}$ & 0.028 & 0.031 & \\
\hline Zeolites & 9.342 & 1.661 & \\
\hline $\mathrm{ZnO}$ & 0.043 & 0.341 & \\
\hline $\mathrm{ZO}_{2}$ & 1.842 & 3.828 & \\
\hline
\end{tabular}




\section{SPECIAL FEATURES OF THE SLUDGE SIMULANTS}

- Carbonates and nitrites lead to copious gas evolution $\left(\mathrm{CO}_{2}, \mathrm{NO}, \mathrm{N}_{2} \mathrm{O}\right)$ upon treatment with formic acid, i.e.

$\mathrm{HCO}_{2} \mathrm{H}+\mathrm{CO}_{3} 2-\longrightarrow \mathrm{CO}_{2}+\mathrm{HCO}_{2}-\mathrm{OH}^{-}$

$\mathrm{HCO}_{2} \mathrm{H}+\mathrm{NO}_{2}-\left\{\mathrm{HNO}_{2}\right\}+\mathrm{HCO}_{2}-$

$$
\begin{aligned}
& 3 \mathrm{HNO}_{2} \longrightarrow 2 \mathrm{NO}+\mathrm{HNO}_{3}+\mathrm{H}_{2} \mathrm{O} \\
& 2 \mathrm{HNO}_{2}+2 \mathrm{HCO}_{2} \mathrm{H} \longrightarrow \mathrm{N}_{2} \mathrm{O}+2 \mathrm{CO}_{2}+3 \mathrm{H}_{2} \mathrm{O}
\end{aligned}
$$

- Redox-active components, particularly iron(III), might affect the relevant noble metal chemistry (although this point has not yet been investigated)

- The presence of nitrite can affect the noble metal chemistry by forming soluble noble metal nitrosyls or nitro complexes which can affect metal reduction potential
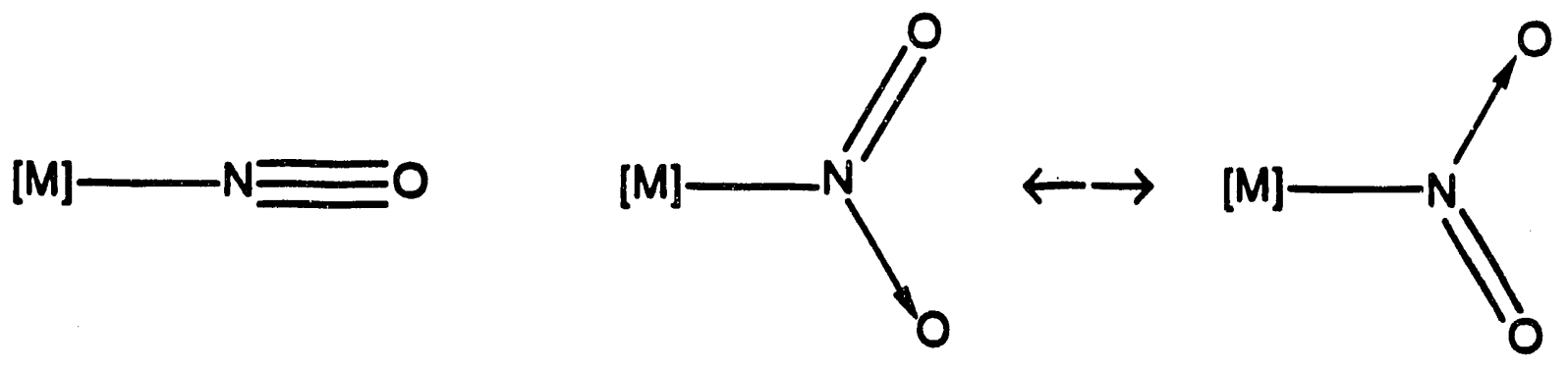

Metal Nitrosyl

Metal Nitro Complex 


\section{STUDIES OF METAL-CATALYZED FORMIC ACID DECOMPOSITION: EXPERIMENTAL DESIGN}

- Reactions are monitored by gas-chromatographic analyses of the gas phase for $\mathrm{H}_{2}, \mathrm{CO}_{2}, \mathrm{NO}, \mathrm{N}_{2} \mathrm{O}$ (as well as $\mathrm{CO}, \mathrm{N}_{2}, \mathrm{O}_{2}$, etc.) as a function of time and temperature.

- A closed system is used of approximately $250 \mathrm{~mL}$ volume (a "static system").

- Argon blanketing is used in most experiments.

- Gas samples are withdrawn as a function of time using gas syringes.

- Two dedicated gas chromatographs are used:

1) $\mathrm{H}_{2}$ analyses: $13 \times$ molecular sieve column on a Varian 90P gas chromatograph.

2) $\mathrm{CO}_{2}, \mathrm{NO}, \mathrm{N}_{2} \mathrm{O}$, analyses,etc.: Columpak $\mathrm{PQ}$ followed by a $13 \times$ molecular sieves column on a Fisher Model 1200 gas partitioner.

- Peak areas are measured directly on a HewlettPackard 3396 Series II Integrator. 


\section{COMPARISON OF STATIC AND FLOW SYSTEMS}

Static System (e.g., UGa work)

- All gaseous components remain in system allowing a more accurate material balance for determination of stoichiometries

- Problems with pressure buildup if large amounts of gases are generated

- Gaseous products (e.g., NO, $\mathrm{N}_{2} \mathrm{O}$ ) formed in early stages of reactions remain in system and thus are available for later reactions

Flow System (e.g., TNX work)

- Gaseous products are continually removed from the system making the determination of reaction stoichiometries less direct

- No problems with pressure buildup since the system remains at ambient pressure

- Gaseous products formed in early stages of reactions are removed and thus are not available for later reactions.

Comparison of data obtained by both methods

- Gas evolution versus time curves obtained by flow methods provide the rates of change $(\partial f / \partial t)$ of gas evolution obtained by the static method:

E.g. A buildup of $\mathrm{H}_{2}$ to a saturation value obtained by the static method will appear as a peak decaying to zero in the flow method 


\section{EXPERIMENTAL PROCEDURE FOR THE SLUDGE SIMULANT EXPERIMENTS}

- Sludge simulant ( $38.5 \mathrm{~mL}$ ) and $88 \%$ formic acid $(1.5 \mathrm{~mL})$ are taken in a $250 \mathrm{~mL}$ reaction vessel equipped with a rubber septum for gas sampling.

- The mixture is flushed with argon.

- A weighed quantity of the metal compound (e.g., $\mathrm{RhCl}_{3} \cdot 3 \mathrm{H}_{2} \mathrm{O}$ ) is added against a countercurrent of argon.

- The reaction mixture is initially stirred at room temperature and the gas phase sampled and analyzed by gas chromatography.

- The reaction mixture is then heated to the desired temperature $\left(80-100^{\circ} \mathrm{C}\right)$ and gas samples are analyzed periodically by gas chromatography 


\section{Summary of the Catalytic Activity of Noble}

Metals in

Formic Acid Decomposition to Hydrogen (Numbers are moles of $\mathrm{H}_{2}$ produced per day per mole of noble metal)

\begin{tabular}{|l|l|l|l|}
\multicolumn{1}{l}{} & Ruthenium & \multicolumn{1}{l}{ Rhodium } & Palladium \\
\hline & $\begin{array}{l}\text { Hydrated } \\
\text { RuCl } 3\end{array}$ & $\begin{array}{l}\text { Hydrated } \\
\mathrm{RhCl}_{3}\end{array}$ & $\mathrm{PdCl}_{2}$ \\
\hline & & & \\
\hline $\begin{array}{l}88 \% \text { Formic } \\
\text { Acida }\end{array}$ & Active & Inactive & Inactive \\
\hline $\begin{array}{l}3.3 \% \text { Formic } \\
\text { Acid }\end{array}$ & 4 & 0 & 3 \\
\hline $\begin{array}{l}3 \% \\
\mathrm{HCO}_{2} \mathrm{H} / \mathrm{NaNO}_{2}\end{array}$ & 3 & 118 & 5 \\
\hline $\begin{array}{l}0.76 \mathrm{M} \\
\mathrm{NaCO}_{2} \mathrm{H}\end{array}$ & 40 & 2.4 & 78 \\
\hline $\begin{array}{l}\text { IDMS sludge } \\
\text { simulant (pH } \\
11.0)\end{array}$ & 0 & 112 & 8 \\
\hline
\end{tabular}

(a) Data taken from Technical report 1 prepared March, 1991, entitled Preliminary Evaluation of Noble Metals as Catalysts for the Decomp ssition of Formic Acid.

CONCLUSIONS from these studies:

- $\mathrm{Rh}$ is the catalytically active noble metal for hydrogen evolution from formic acid in sludge simulants

- Nitrite ion is needed to promote the catalytic activity of Rh. 


\section{NITROUS ACID REACTIONS}

Formation of Nitrous Acid

$\mathrm{NaNO}_{2}+\mathrm{RCO}_{2} \mathrm{H} \longrightarrow \mathrm{HNO}_{2}+\mathrm{RCO}_{2} \mathrm{Na}$

Disproportionation of Nitrous Acid

$3 \mathrm{HNO}_{2} \longrightarrow 2 \mathrm{NO}+\mathrm{HNO}_{3}+\mathrm{H}_{2} \mathrm{O}$

Reduction of Nitrous Acid with Formate

$2 \mathrm{HNO}_{2}+2 \mathrm{HCO}_{2}-\longrightarrow \mathrm{N}_{2} \mathrm{O}+2 \mathrm{OH}^{-}+\mathrm{H}_{2} \mathrm{O}+2 \mathrm{CO}_{2}$

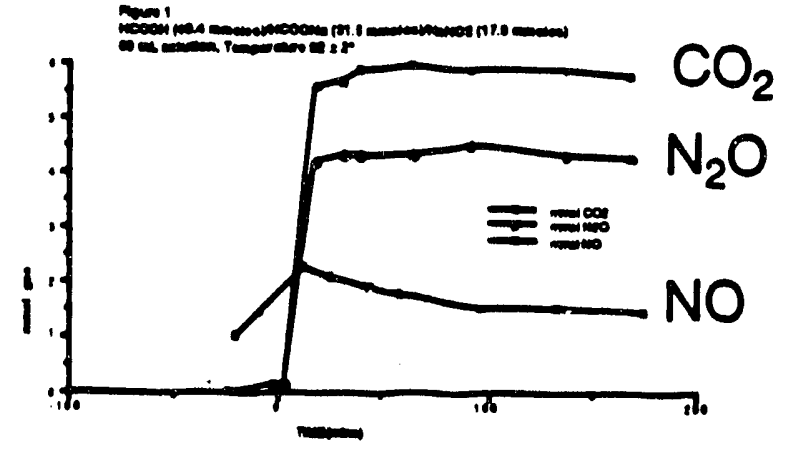

Formic acid $+\mathrm{NaNO}_{2}$

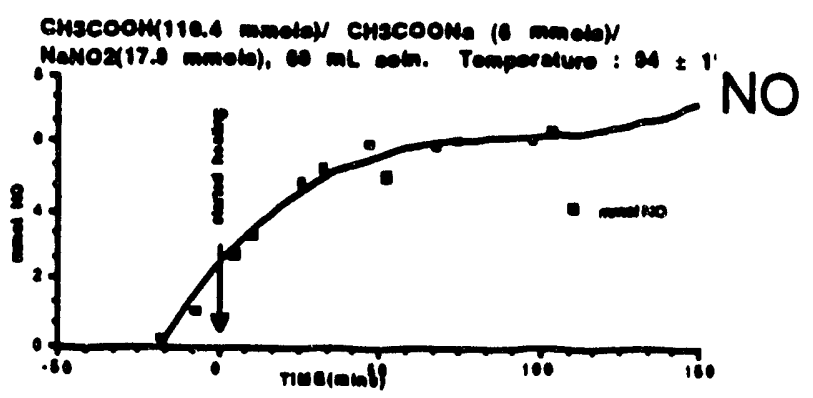

Acetic acid $+\mathrm{NaNO}_{2}$

- Disproportionation of nitrous acid as indicated by

NO production also increases the nitrate

concentration! 


\section{SUMMARY OF THE CATALYTIC ACTIVITY OF NOBLE METALS IN FORMIC ACID DECOMPOSITION TO HYDROGEN}

(Numbers are moles of $\mathrm{H}_{2}$ produced per day per mole of noble metal)

\begin{tabular}{|l|l|l|l|}
\multicolumn{2}{l}{ Ruthenium } & Rihodium & Palladium \\
\hline & Hydrated $\mathrm{RuCl}_{3}$ & ${\text { Hyydrated } \mathrm{RhCl}_{3}}_{3}$ & $\mathrm{PdCl}_{2}$ \\
\hline & & & \\
\hline $\begin{array}{l}\text { 88\% Formic } \\
\text { Acida }\end{array}$ & Active & Inactive & Inactive \\
\hline $\begin{array}{l}3.3 \% \text { Formic } \\
\text { Acid }\end{array}$ & 4 & 0 & 3 \\
\hline $\begin{array}{l}3 \% \\
\mathrm{HCO}_{2} \mathrm{H} / \mathrm{NaNO}_{2}\end{array}$ & 3 & 118 & 5 \\
\hline $\begin{array}{l}0.76 \mathrm{M} \\
\mathrm{NaCO}_{2} \mathrm{H}\end{array}$ & 40 & 2.4 & 78 \\
\hline $\begin{array}{l}\mathrm{HM} \mathrm{high} \mathrm{nitrite} \\
\text { sludge simulant } \\
\text { (pH 11.0) }\end{array}$ & 0 & 112 & 8 \\
\hline $\begin{array}{l}\text { IDMS low nitrite } \\
\text { Purex sludge } \\
\text { simulant (pH } \\
12.0) \dagger\end{array}$ & & $\begin{array}{l}580\left(95^{\circ} \mathrm{C}\right) \\
740\left(92^{\circ} \mathrm{C}\right) \\
170\left(92^{\circ} \mathrm{C}\right)\end{array}$ & \\
$64\left(87^{\circ} \mathrm{C}\right)$ & \\
$40\left(100^{\circ} \mathrm{C}\right)$ & \\
$280\left(100^{\circ} \mathrm{C}\right)$ & \\
\hline
\end{tabular}

† Extremely variable induction periods $(0.5-6.0 \mathrm{hrs}$.)

CONCLUSIONS from these studies:

- $\mathrm{Rh}$ is the catalytically active noble metal for hydrogen evolution from formic acid in sludge simulants

- Nitrite ion is needed to promote the catalytic activity of Rh.

- Low nitrite Purex sludge simulant gives erratic results 


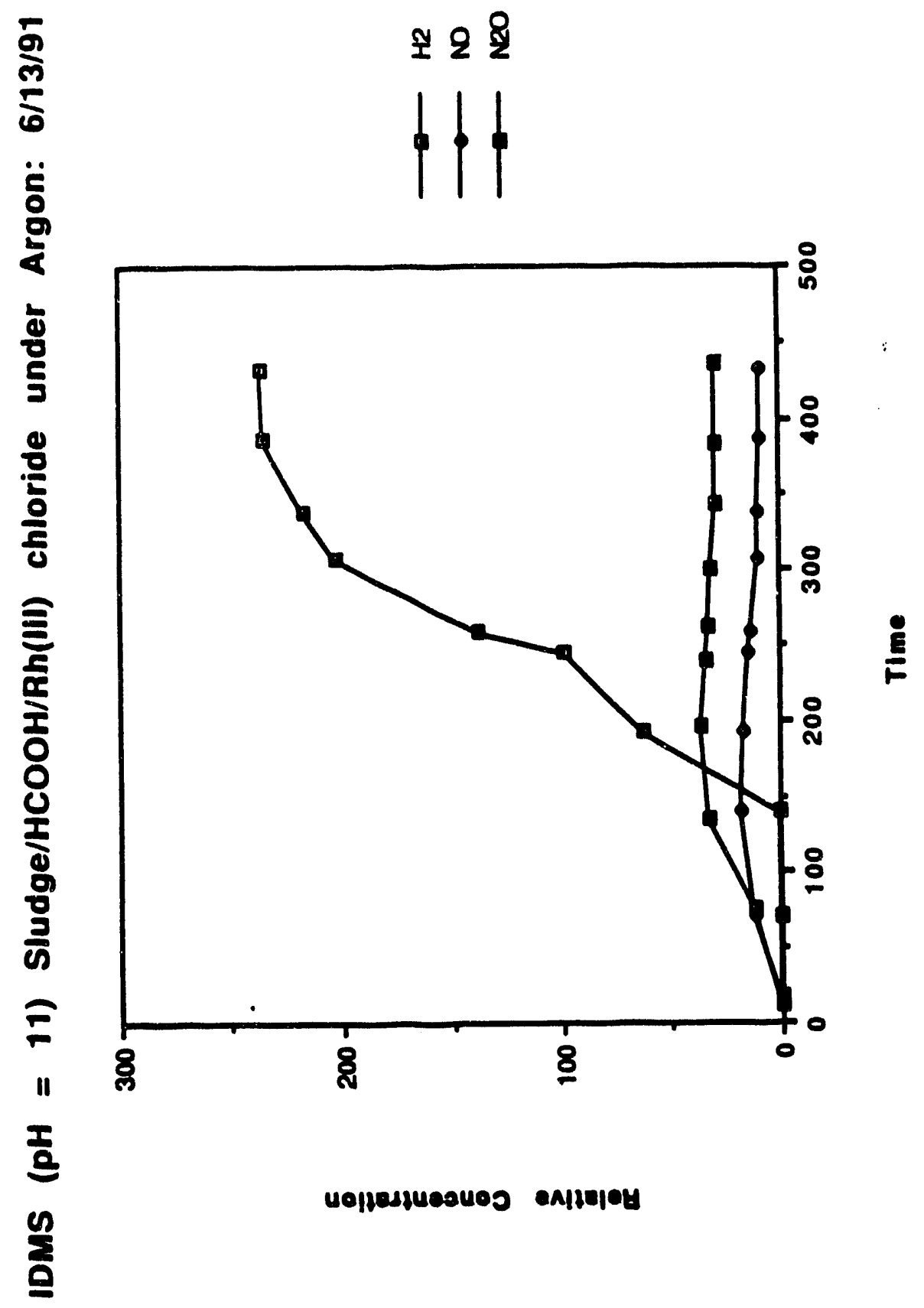




\section{RhCl $3(0.21 \mathrm{mmol}) / 1$ DMS PH 11(38.5ml)}

/Formlc Acld(1.5mI)/Air

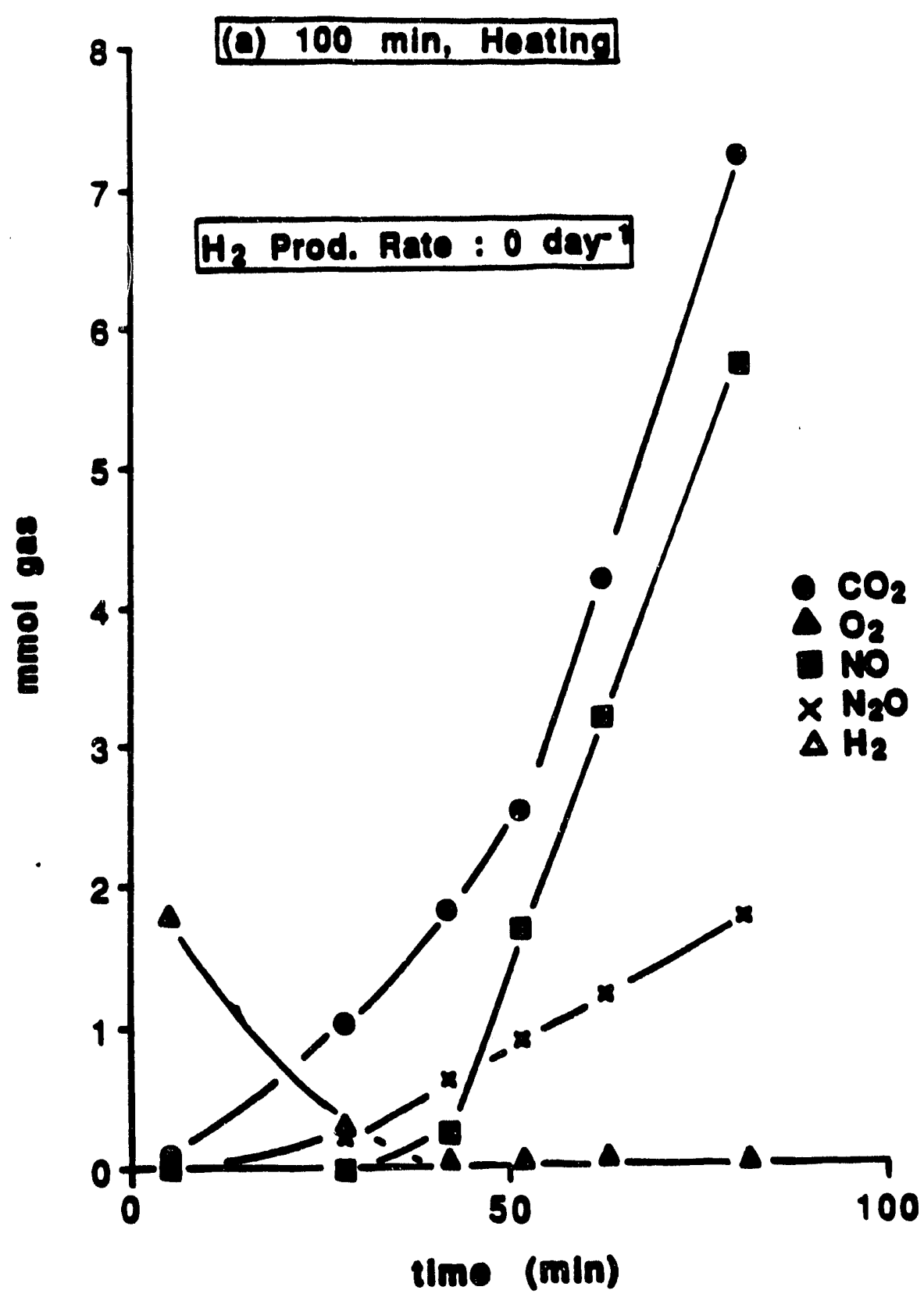




\section{$\mathrm{RhCl}_{3}(0.21 \mathrm{mmol}) / / \mathrm{DMS}$ PH $11(38.5 \mathrm{ml})$}

/Formlc Acld(1.5ml)/Alr

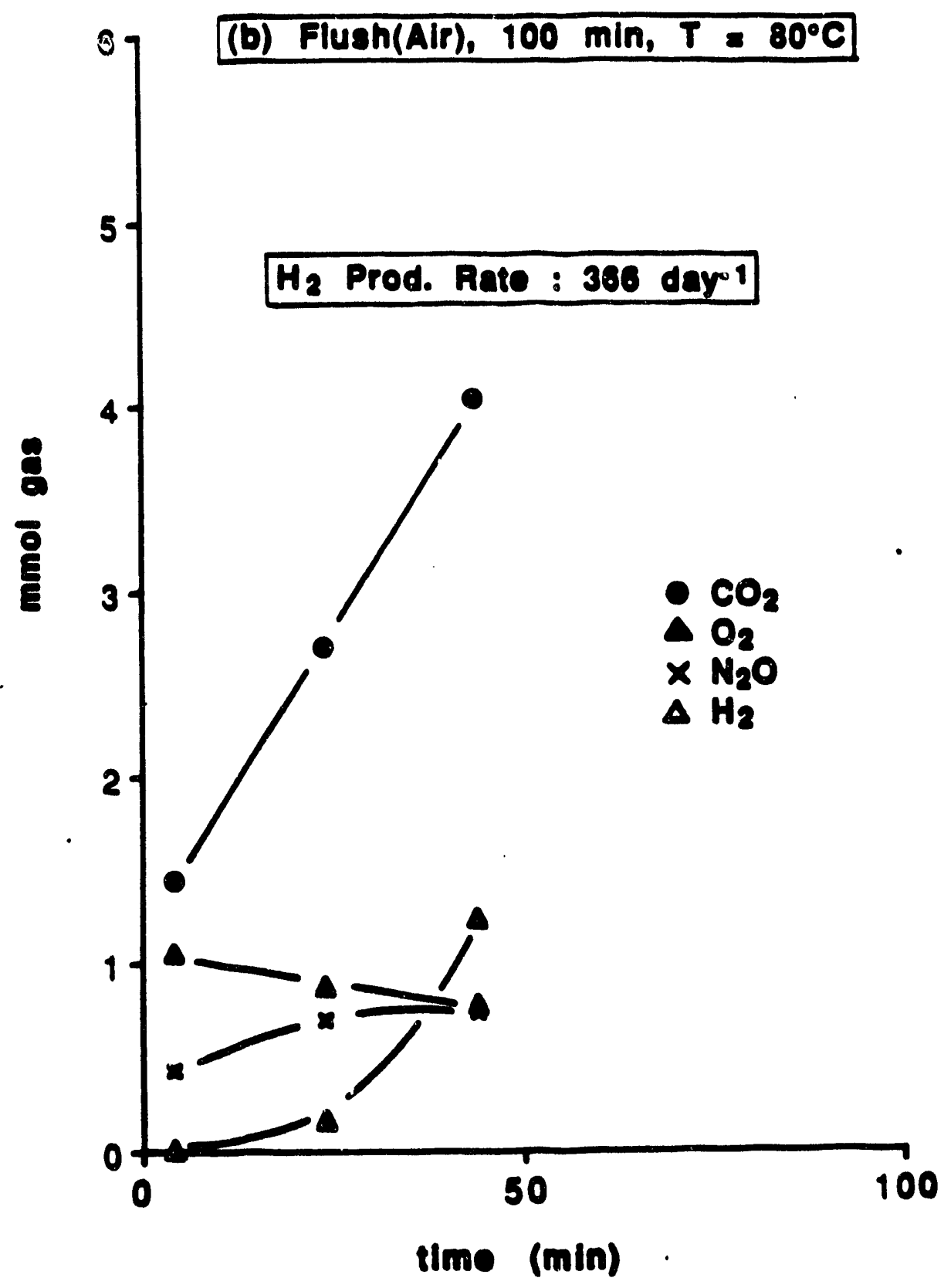


$\mathrm{RhCl}_{3}(0.21 \mathrm{mmol}) / 1 \mathrm{DMS} \mathrm{PH} \quad 11(38.5 \mathrm{ml})$ /Formlc Acld(1.5ml)/Air

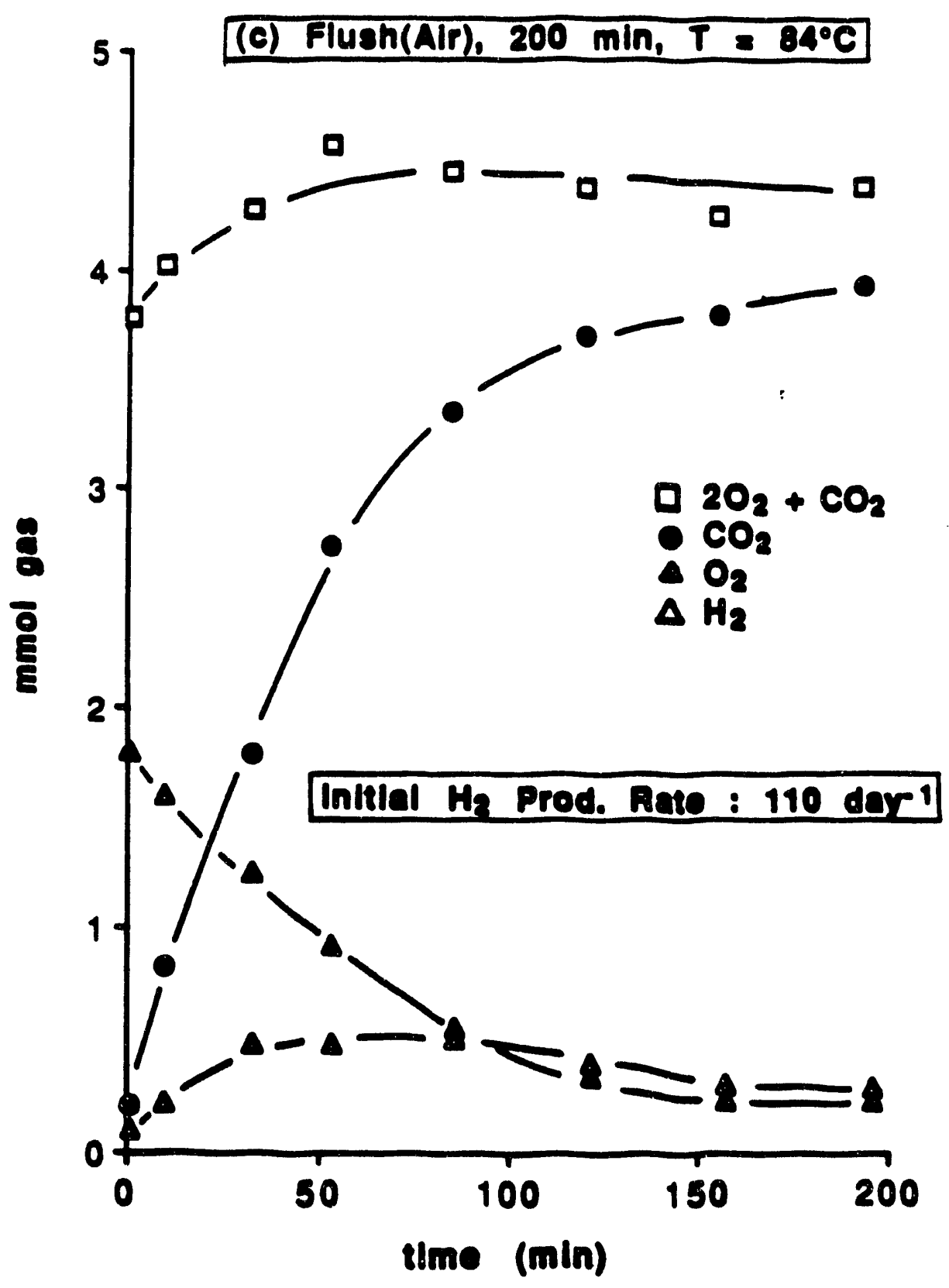




\section{$\mathrm{RhCl}_{3}(0.22 \mathrm{mmol}) / 1 \mathrm{DMS}$ PH 11(38.5m $)$}

/Formic Acld(1.5mI)/Ar, $T=84^{\circ} \mathrm{C}$

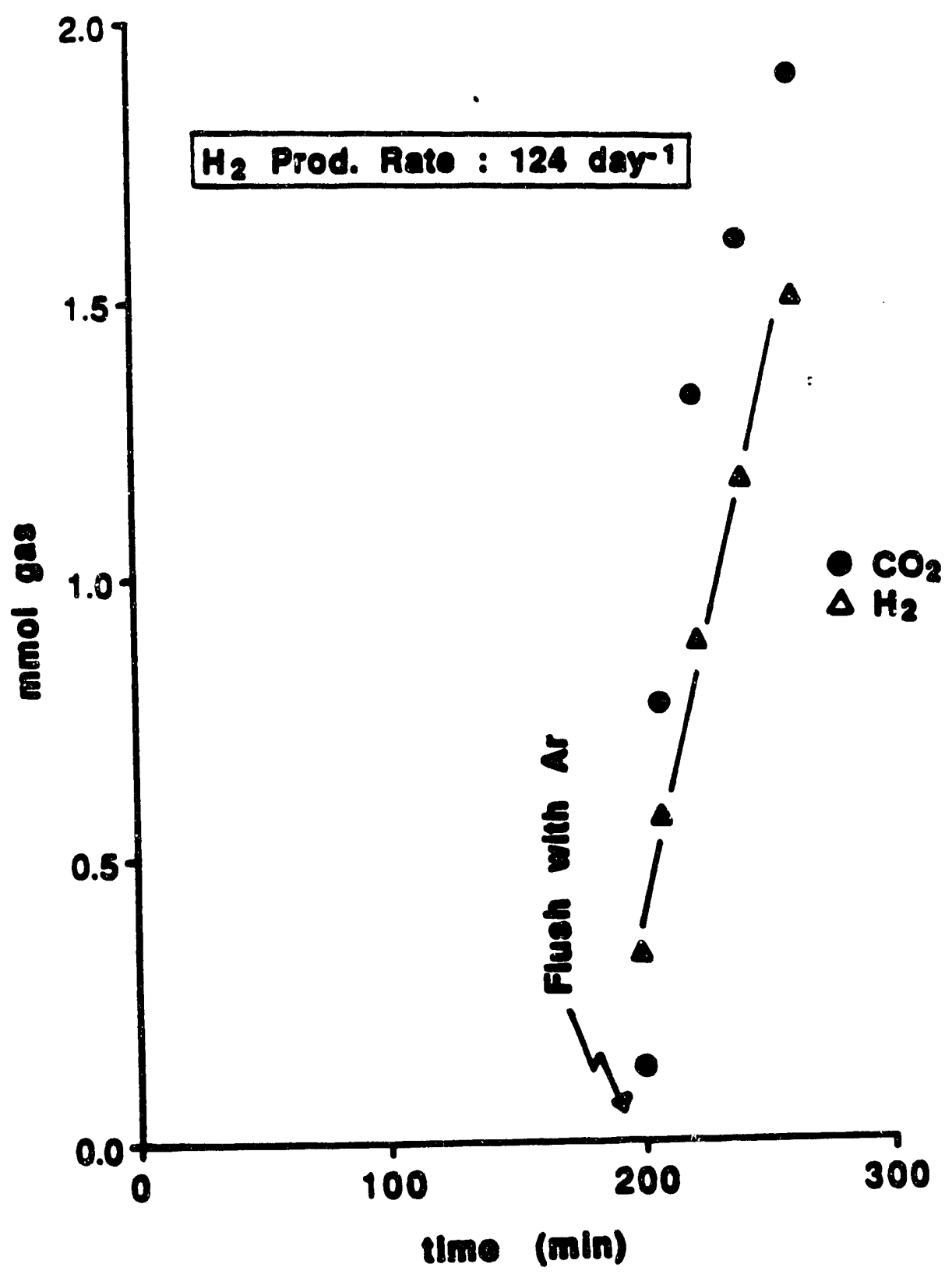


HYDROGEN EVOLUTION FROM FORMIC ACID IN LOW NITRITE $\left(\sim 2.5 \% \mathrm{NaNO}_{2}\right) \mathrm{pH}=12$ SLUDGE SIMULANT USING A RHODIUM CATALYST

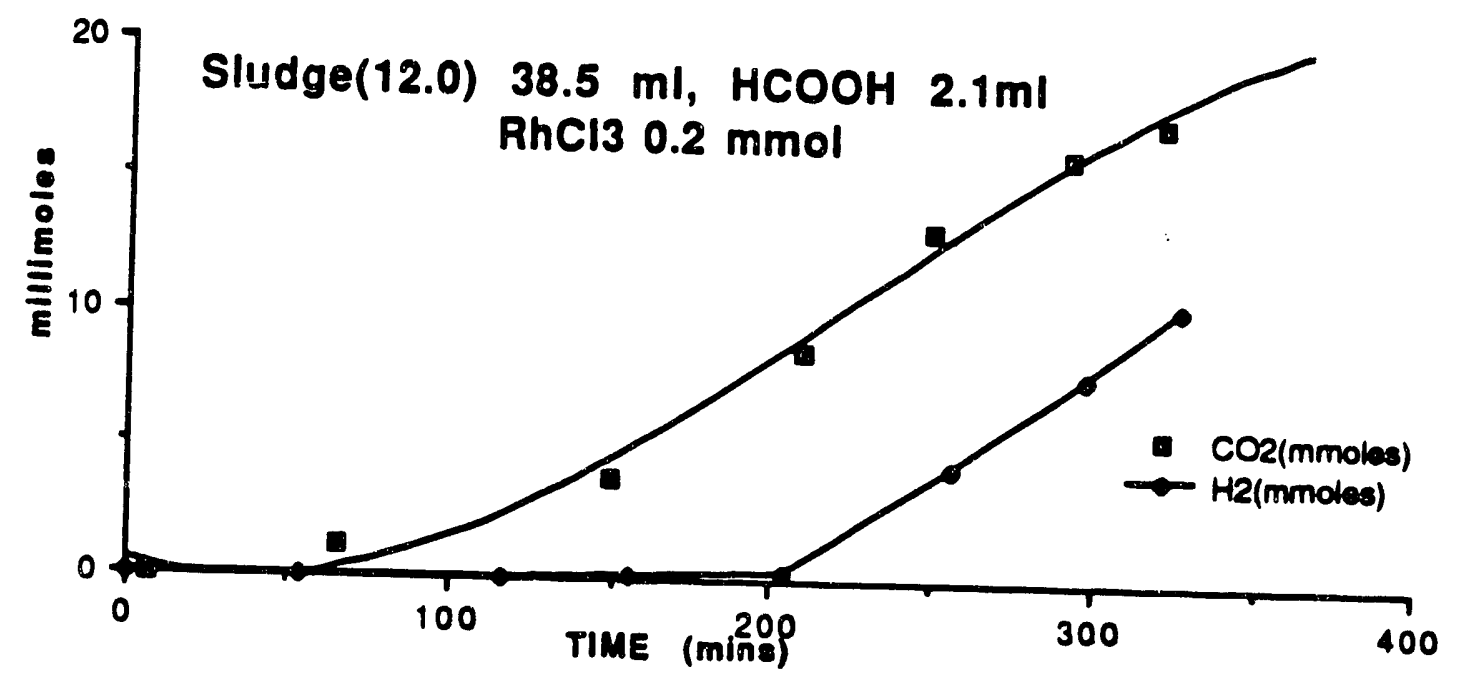

Features:

- $\mathrm{H}_{2}$ evolution after an induction period $(\sim 200 \mathrm{~min}$ in this experiment)

- The expected copious $\mathrm{CO}_{2}$ evolution from the carbonate in the sludge simulant as well as from formic acid decomposition $\left(\mathrm{HiO}_{2} \mathrm{H} \longrightarrow \mathrm{H}_{2}+\mathrm{CO}_{2}\right)$.

- Nitrogen oxides ( $\mathrm{NO}$ and $\mathrm{N}_{2} \mathrm{O}$ ) not produced in significant quantities in low nitrite sludge experiments. 


\section{EFFECT OF ADDED NITRITE ON Rh-CATALYZED HYDROGEN EVOLUTION FROM LOW NITRITE $\mathrm{pH}=12$ PUREX SLUDGE SIMULANT}

$38.5 \mathrm{~mL}$ Sludge Simulant, $2.1 \mathrm{~mL} \mathrm{HCO} 2 \mathrm{H}$, 9.1 mmoles $\mathrm{NaNO}_{2}, 0.2$ mmoles $\mathrm{RhCl}_{3} \cdot 3 \mathrm{H}_{2} \mathrm{O}, 91 \pm 2^{\circ} \mathrm{C}$,

Figure 3 $\mathrm{CO}_{2}$ omitted for clarity

Bottle 1 pH 12 Sludge $(38.5 \mathrm{~mL})$, HCOOH $(2.1 \mathrm{~mL}$

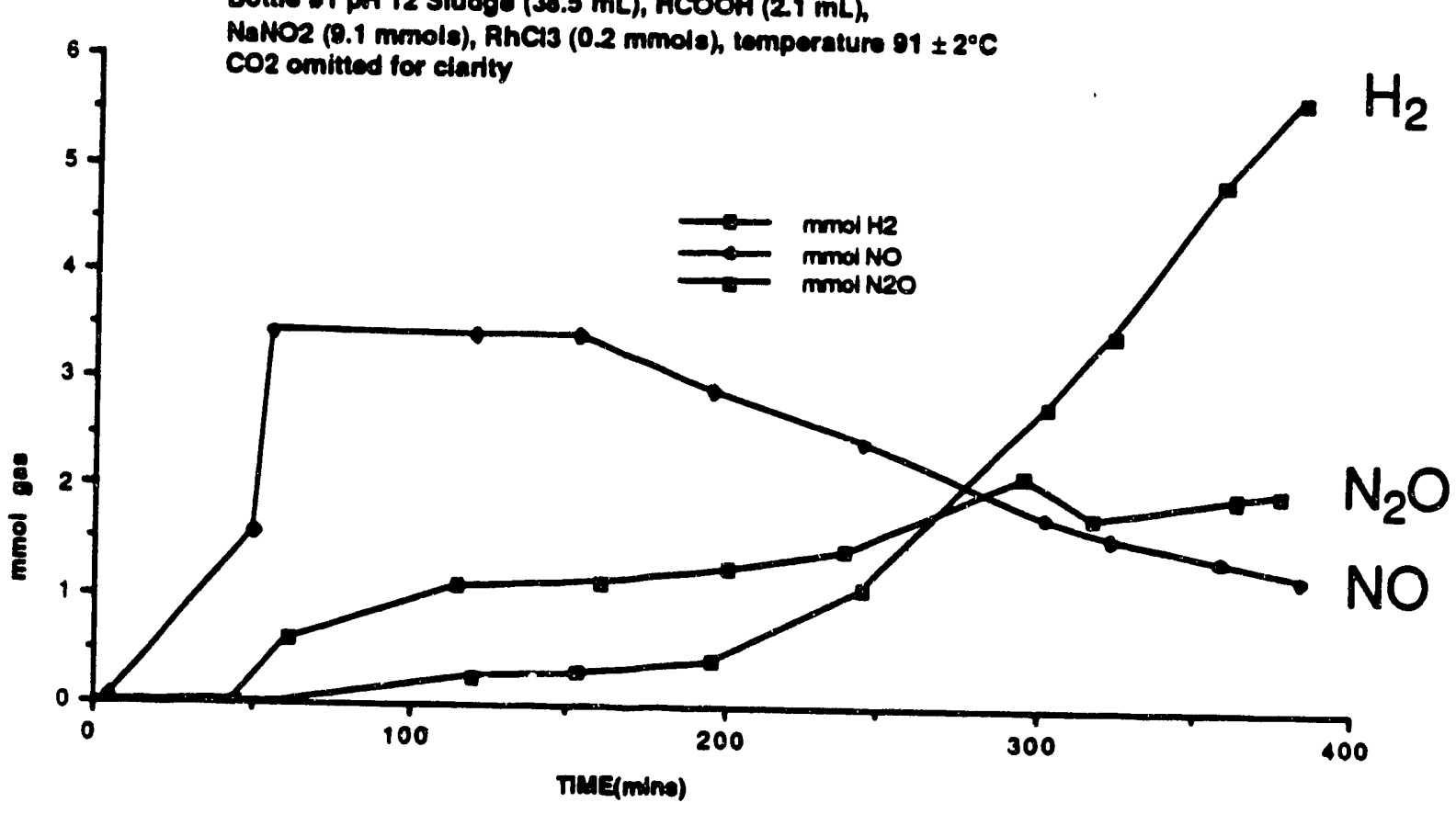

- $\quad$ Addition of nitrite to low nitrite sludge simulant leads to nitrous acid chemistry not found in the absence of added nitrite

- Initially produced NO is consumed upon further reaction $\Rightarrow$ Reduction to $\mathrm{N}_{2} \mathrm{O}$ and possibly $\mathrm{NH}_{3}$ (not yet proven) 


\section{INHIBITORS FOR THE Rh- CATALYZED GENERATION OF HYDROGEN FROM FORMIC ACID}

- Aminopolycarboxylic acids such as ethylenediamine tetraacetic acid (EDTA) and nitrilotriacetic acid (NTA).

- Mercury as $\mathrm{Hg}^{0}$ or $\mathrm{HgCl}_{2}$

Other potential inhibitors evaluated which appear unpromising:

- Dimethylglyoxime

- Oxalic acid

- Sodium sulfide

- Trimethyl phosphite

- Thiourea 


\section{INHIBITION OF HYDROGEN PRODUCTION WITH AMINOPOLYCARBOXYLIC ACIDS}

All experiments were done with $30 \mathrm{~mL}$ of low nitrite $\mathrm{pH} 12.0$ Purex sludge simulant and $1.6 \mathrm{~mL} 88 \%$ formic acid with 0.056 mmoles $\mathrm{RhCl}_{3} \cdot \mathrm{H}_{2} \mathrm{O}$ at $100 \pm 2^{\circ} \mathrm{C}$.

mmoles mmoles $\mathrm{H}_{2}$ turnover / $\mathrm{pH}$ at end of additive additive/Rh day * expt.

A. No additive

0

0

80

6.2

B. Ethylenediamine tetraacetic acid (EDTA)

$\begin{array}{lccc}0.52 & 6.7 & 85 & 4.8 \\ 0.77 & 13.8 & 35 & 5.7 \\ 1.04 & 18.6 & \sim 0 & 4.0\end{array}$

C. Nitrilotriacetic acid (NTA)

$\begin{array}{lccc}0.21 & 3.8 & 90 & 5.0 \\ 0.35 & 6.2 & & 0 \\ 0.52 & 9.3 & \sim 0 & 4.7 \\ 0.99 & 17.7 & \sim 0 & 4.7 \\ 1.05 & 18.8 & \sim 0 & 4.7 \\ 1.57 & 28.0 & \sim 0 & 4.3\end{array}$

"The designation " 0 " means that negligible $\mathrm{H}_{2}$ was produced after waiting at least $5 \mathrm{hr}$.<smiles>O=C(O)CN(CCN(CC(=O)O)CC(=O)O)CC(=O)O</smiles>

EDTA<smiles>O=C(O)CN(CC(=O)O)CC(=O)O</smiles>

NTA 


\section{RECOMMENDATIONS BASED ON \\ THE NITRILOTRIACETIC ACID (NTA) EXPERIMENTS}

- Nitrilotriacetic acid is a useful inhibitor for the rhodium-catalyzed hydrogen generation from formic acid

- $\quad$ Our experiments with low nitrite $\mathrm{pH}=12.0$ Purex sludge simulant indicate:

$\checkmark \quad$ A NTARh mole ratio of 6.2 corresponding to $\sim 67 \mathrm{mg}$. NTA appears to completely inhibit hydrogen production in an experiment using $1.6 \mathrm{~mL} 88 \%$ formic acid and 0.056 mmoles of rhodium as $\mathrm{RhCl}_{3} \cdot 3 \mathrm{H}_{2} \mathrm{O} \Rightarrow$

$\checkmark \quad \mathrm{H}_{2}$ production can be inhibited by using a $\frac{67 \times 100}{1600}=\sim 4 \%$ solution of NTA in $88 \%$ formic acid rather than pure $88 \%$ formic acid for the process in the DWPF plant.

Some important remaining questions:

- Effect of NTA on the catalytic activity of other noble metals, particularly Ru.

- Effect of small amounts of the NTA on the glass melter. 


\section{EVALUATION OF OTHER INHIBITORS FOR THE Rh- CATALYZED GENERATION OF HYDROGEN FROM FORMIC ACID}

mmoles Rh as mmoles $\mathrm{RhCl}_{3} \cdot 3 \mathrm{H}_{2} \mathrm{O} \quad \mathrm{NaNO}_{2}$
Additive mmoles additive
$\mathrm{H}_{2}$ Turnover per $24 \mathrm{hr}$.

A. Experiments with $0.76 \mathrm{M}$ Aqueous Formic Acld

$\begin{array}{llcllc}0.21 & 1.18 & \text { dimethylglyoxime } & 0.44 & 90 & 167 \\ 0.19 & 1.17 & \text { oxalic acid } & 0.41 & 95 & 79 . \\ 0.20 & 1.17 & \text { EDTA } & 0.43 & 85 & 0\end{array}$

B. Experiments with the IDMS (pH 11.0) Sludge Simulant

$\begin{array}{cccccc}0.18 & 0 & \text { none } & 0 & 82 & 112 \\ 0.19 & 0 & \mathrm{Na}_{2} \mathrm{~S} & 2.17 & & \begin{array}{c}\text { high } \\ 0.21\end{array} \\ 0.20 & 0 & \mathrm{TeO}_{2} & 2.0 & 80 & 62 \\ 0.13 & 0 & (\mathrm{MeO})_{3} \mathrm{P} & 2.0 & 82 & 117 \\ 0.2 & \mathrm{HgCl} & 0.97 & 85 & 7 \\ 0.2 & 0 & \mathrm{HgCl}_{2} & 2.0 & 96 & 1.3 \\ 0.2 & 0 & \mathrm{HgCl}_{2} & 19.6 & 96 & 0.01 \\ 0.2 & 0 & \text { EDTA } & 21.5 & 95 & 0 \\ & & \text { EDTA } & 2.2 & 96 & 16\end{array}$




\section{POSSIBLE MECHANISMS FOR THE Rh-CATALYZED \\ GENERATION OF HYDROGEN FROM FORMIC ACID}

Homogeneous catalysis:

Unstable soluble rhodium complex $\Rightarrow$

- Catalyst deactivated by reduction to catalytically inactive rhodium metal

- Role of nitrite ion in generating nitrorhodium catalyst intermediates

- Catalyst inhibition by strongly complexing ligands, e.g., EDTA or NTA, tying up active sites

Heterogeneous catalysis:

Small catalytically active rhodium metal clusters obtained by reduction of soluble rhodium compounds to the metal

- Catalyst deactivated by aggregation to larger particles

- Non-specific effects of added ions in affecting aggregation of the small rhodium metal clusters

- Catalyst inhibition by preventing reduction of soluble rhodium compounds to the metal 


\section{POSSIBLE ROLE OF NITRORHODIUM COMPLEXES IN THE HOMOGENEOUS CATALYSIS OF $\mathrm{H}_{2}$ PRODUCTION FROM FORMIC ACID}

$\mathrm{RhCl}_{3}\left(\mathrm{H}_{2} \mathrm{O}\right)_{3}+6 \mathrm{NO}_{2}-\longrightarrow\left[\mathrm{Rh}\left(\mathrm{NO}_{2}\right)_{6}\right]^{3-}+3 \mathrm{H}_{2} \mathrm{O}+3 \mathrm{Cl}^{-}$

Reported preparative method for $\mathrm{M}_{3}\left[\mathrm{Rh}\left(\mathrm{NO}_{2}\right)_{6}\right]$ salts $\left(\mathrm{M}=\mathrm{Na}, \mathrm{K}, \mathrm{NH}_{4}\right.$, etc.)

Substitution equilibria

$\left[\mathrm{Rh}\left(\mathrm{NO}_{2}\right)_{6}\right]^{3-}+\mathrm{H}_{2} \mathrm{O} \rightleftarrows\left[\mathrm{Rh}\left(\mathrm{NO}_{2}\right)_{5}\left(\mathrm{H}_{2} \mathrm{O}\right)\right]^{2-}+\mathrm{NO}_{2}-$

$\left[\mathrm{Rh}\left(\mathrm{NO}_{2}\right)_{5}\left(\mathrm{H}_{2} \mathrm{O}\right)\right]^{2-}+\mathrm{H}_{2} \mathrm{O} \rightleftarrows\left[\mathrm{Rh}\left(\mathrm{NO}_{2}\right)_{4}\left(\mathrm{H}_{2} \mathrm{O}\right)_{2}\right]^{-}+\mathrm{NO}_{2}-$

$\left[\mathrm{Rh}\left(\mathrm{NO}_{2}\right)_{4}\left(\mathrm{H}_{2} \mathrm{O}\right)_{2}\right]^{-}+\mathrm{H}_{2} \mathrm{O} \rightleftarrows \mathrm{Rh}\left(\mathrm{NO}_{2}\right)_{3}\left(\mathrm{H}_{2} \mathrm{O}\right)_{3}+\mathrm{NO}_{2}-$

Introduction of Formate

$\left[\mathrm{Rh}\left(\mathrm{NO}_{2}\right)_{4}\left(\mathrm{H}_{2} \mathrm{O}\right)_{2}\right]^{-}+\mathrm{HCO}_{2}-$

$$
\left[\mathrm{Rh}\left(\mathrm{NO}_{2}\right)_{4}\left(\mathrm{H}_{2} \mathrm{O}\right)\left(\mathrm{HCO}_{2}\right)\right]+\mathrm{H}_{2} \mathrm{O}
$$

Decomposition of Formate

$\left.\left[\mathrm{Rh}\left(\mathrm{NO}_{2}\right)_{4}\left(\mathrm{H}_{2} \mathrm{O}\right) \mathrm{HCO}_{2}\right)\right]^{-} \longrightarrow\left[\mathrm{Rh}\left(\mathrm{NO}_{2}\right)_{4}\left(\mathrm{H}_{2} \mathrm{O}\right) \mathrm{H}\right]-+\mathrm{CO}_{2}$

$\left[\mathrm{Rh}\left(\mathrm{NO}_{2}\right)_{4}\left(\mathrm{H}_{2} \mathrm{O}\right) \mathrm{H}\right]^{-}+\mathrm{H}_{2} \mathrm{O} \longrightarrow$

$\left[\mathrm{Rh}\left(\mathrm{NO}_{2}\right)_{4}\left(\mathrm{H}_{2} \mathrm{O}\right)(\mathrm{OH})\right]^{2-}+\mathrm{H}_{2}$

$\left[\mathrm{Rh}\left(\mathrm{NO}_{2}\right)_{4}\left(\mathrm{H}_{2} \mathrm{O}\right)(\mathrm{OH})\right]^{2-}+\mathrm{HCO}_{2} \mathrm{H} \longrightarrow$

$\left[\mathrm{Rh}\left(\mathrm{NO}_{2}\right)_{4}\left(\mathrm{H}_{2} \mathrm{O}\right)_{2}\right]^{-}+\mathrm{HCO}_{2}-$

Sum of Equations 5-8

$\mathrm{HCO}_{2} \mathrm{H} \longrightarrow \mathrm{CO}_{2}+\mathrm{H}_{2}$

Implications of Mechanistic Scheme

Nitrite ion essential to reaction

- Excess nitrite, however, can inhibit reaction by tying up catalytic sites forming $\left[\mathrm{Rh}\left(\mathrm{NO}_{2}\right)_{6}\right]^{3-}$ 


\section{EFFECT OF NITRITE CONCENTRATION ON $\mathrm{H}_{2}$ PRODUCTION WHEN $\left[\mathrm{NaCO}_{2} \mathrm{H}\right] /\left[\mathrm{HCO}_{2} \mathrm{H}\right]=0.64(\mathrm{pH}=$ 3.5)}

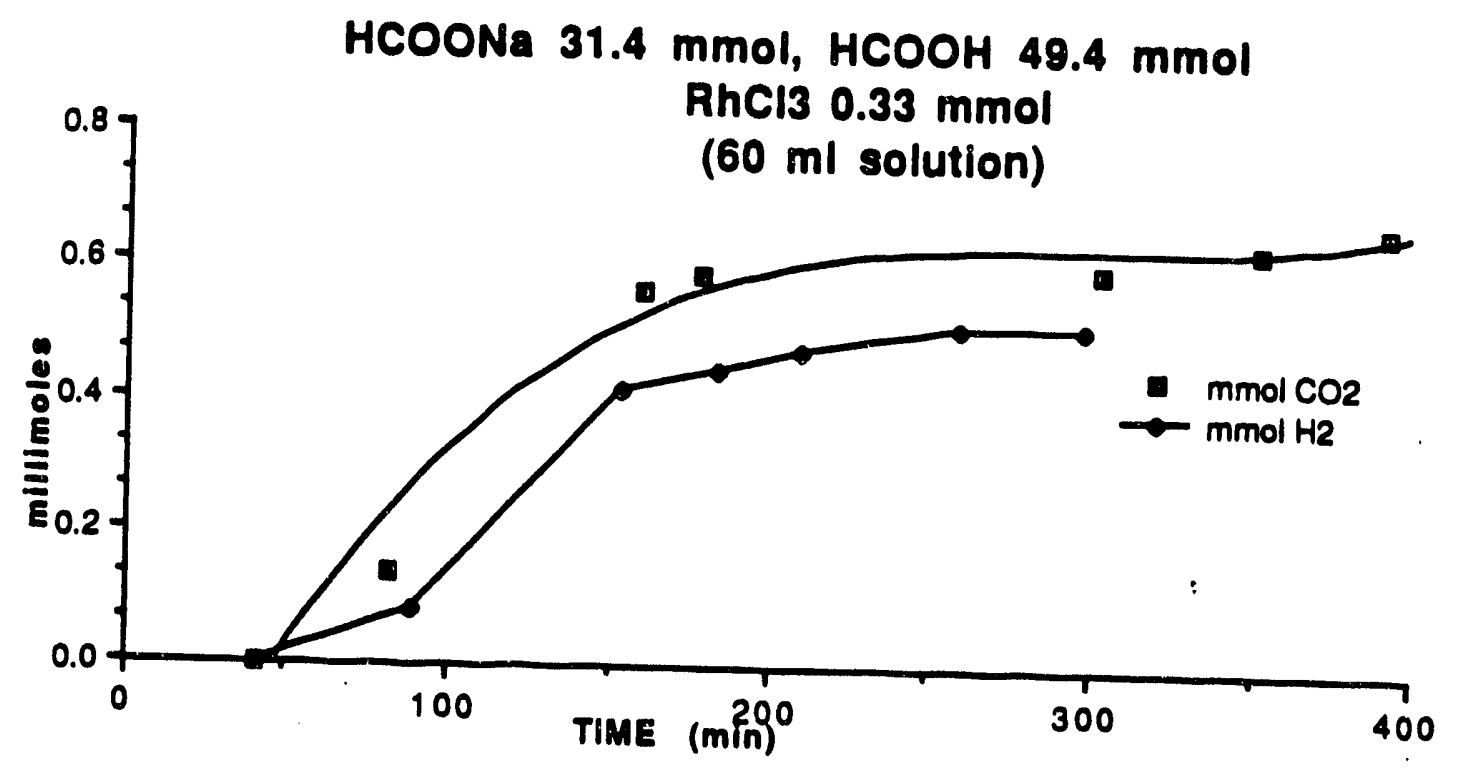

mmoles $\mathrm{H}_{2}$ at end $/ \mathrm{mmoles} \mathrm{Rh}=0.5 / 0.33 \approx 1.5$ (at $90^{\circ} \mathrm{C}$ ) Turnover number $\approx 21 \mathrm{mmoles} \mathrm{H}_{2} / \mathrm{mmole} \mathrm{Rh} / \mathrm{day}$

HCOONa $31.4 \mathrm{mmol}$, HCOOH $49.4 \mathrm{mmol}$

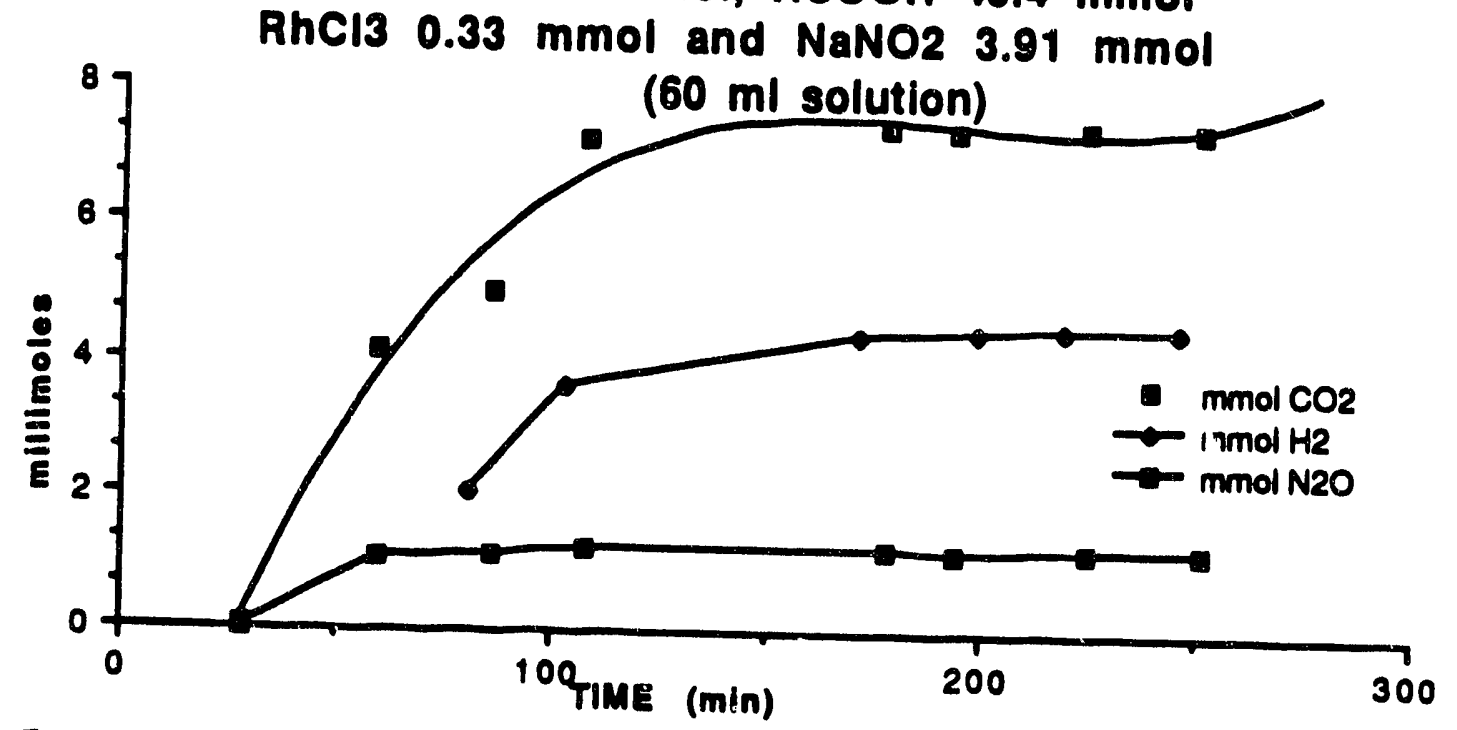

Turnover number $=275 \mathrm{moleH}_{2} / \mathrm{mole} \mathrm{Rh} /$ day at $83^{\circ} \mathrm{C}$ 


\section{EFFECTS OF ADDED IONS ON THE PRODUCTION OF HYDROGEN FROM FORMIC ACID AND $\mathrm{RhCl}_{3} \cdot 3 \mathrm{H}_{2} \mathrm{O}$}

Experimental Conditions: 0.077 mmoles $\mathrm{RhCl}_{3} \cdot 3 \mathrm{H}_{2} \mathrm{O}$, 0.311 mmoles of the ion, $1.5 \mathrm{~mL} 88 \%$ formic acid, $38.5 \mathrm{~mL}$ water, $96 \pm 2{ }^{\circ} \mathrm{C}$

\begin{tabular}{cccc} 
Added lon & Time, min. & mmoles $\mathrm{H}_{2}$ & mmoles $\mathrm{CO}_{2}$ \\
\hline $\mathrm{NO}_{2}-$ & 143 & 0.542 & 1.23 \\
$\mathrm{SO}_{4}{ }^{2-}$ & 139 & 0.122 & 0.170 \\
$\mathrm{NO}_{3}-$ & 124 & 0.097 & 0.146 \\
$\mathrm{NO}_{3}-$ & 427 & 0.444 & 0.321 \\
$\mathrm{Cl}-$ & 139 & 0.071 & 0.119 \\
$\mathrm{~F}-$ & 121 & 0.025 & 0.245
\end{tabular}

- Nitrite appears to be a much better catalyst promoter than the other ions $\Rightarrow$ possible special role of nitrorhodium complexes in catalytic cycle 


\section{OBSERVATIONS SUGGESTING HETEROGENEOUS CATALYSIS}

A. Experiments with the PUREX simulant:

- Poor reproducible behavior

- Variable induction periods

- Apparently random inhomogeneities

B. Experiments on the "ideal" $\mathrm{RhCl} / 3 / \mathrm{NaNO}_{2}$ system:

- Random catalyst life ( $\mathrm{pH}$ important)

- Bursts of hydrogen appear to correlate with formation of Rh particles

- Rh catalyst becomes inactive when particles aggregate decreasing the effective surface area

- Rh particles observed at $\geq 75^{\circ} \mathrm{C}$

- Fractional nitrite order

- Experiments with $\mathrm{RhCl}_{3} / \mathrm{NaNO}_{2}$ at $96^{\circ} \mathrm{C}$ :

0 Orange $\rightarrow$ colorless $\left[\mathrm{Rh}\left(\mathrm{NO}_{2}\right)_{6}\right]^{3-}$

$\checkmark$ Add formic acid:

Colorless $\rightarrow$ orange $\rightarrow$ black suspension

$\mathrm{H}_{2}$ "uurst" 


\section{CURRENT UNDERSTANDING OF THE EFFECTS OF VARIABLE ON THE HYDROGEN PRODUCTION RATE IN THE RHODIUM- CATALYZED DECOMPOSITION OF FORMIC ACID}

- Nitrite is an active promoter for the Rh-catalyzed production of hydrogen from formic acid

- Under ideal conditions the catalyst has a relatively short lifetime $\Rightarrow$ hydrogen production occurs in "bursts" $\Rightarrow$ reliable quantitative reaction rate measurements are difficult

- Hydrogen production is inhibited by added aminopolycarboxylic acids with nitrilotriacetic acid (NTA) being more effective than ethylenediamine tetraacetic acid (EDTA)

- Hydrogen production is inhibited by the addition of mercury or its compounds 


\section{REALISTIC PLANS FOR THE REMAINING FUNDED PERIOD (THREE-MONTHS) OF THE FORMIC ACID DECOMPOSITION PROJECT}

- Evaluation of nitrilotriacetic acid (NTA) as an inhibitor:

Effect on catalytic activity of other metals, particularly Ru

- Evaluation of the role of nitrite: Determination of catalytic activity of noble metals $(\mathrm{Ru}, \mathrm{Rh}, \mathrm{Pd})$ in nitrite-free sludge simulant

- Evaluation of the role of solid metal oxides on the catalytic activity of the $\mathrm{Rh} / \mathrm{NO}_{2}$ - system for formic acid decomposition in "ideal" systems:

$\mathrm{Al}_{2} \mathrm{O}_{3}$ (redox inactive)

$\mathrm{Fe}_{2} \mathrm{O}_{3}$ (redox active) 


\section{REALISTIC PLANS FOR THE \\ REMAINING FUNDED PERIOD \\ (THREE-MONTHS) OF THE \\ FORMIC ACID DECOMPOSITION \\ PROJECT}

- Evaluation of nitrilotriacetic acid (NTA) as an inhibitor:

Effect on catalytic activity of other metals, particularly Ru

- Evaluation of the role of nitrite:

Determination of catalytic activity of noble metals ( $R u, R h, P d)$ in nitrite-free sludge simulant

- Evaluation of the role of solid metal oxides on the catalytic activity of the $\mathrm{Rh} / \mathrm{NO}_{2}$ - system for formic acid decomposition in "ideal" systems:

$\mathrm{Al}_{2} \mathrm{O}_{3}$ (redox inactive)

$\mathrm{Fe}_{2} \mathrm{O}_{3}$ (redox active) 


\title{
TECHNICAL REPORT
}

wo the

Westinghouse Savannah River Laboratory

Aiken, Souch Carolina

on

\section{ELUCIDATION OF NOBLE METAL/FORMIC ACID CHEMISTRY DURING DWPF FEED PREPARATION \\ by}

R. B. King, Regenes' Professor and Principal Investigator

A. D. King, Jr.. Professor and Faculty Associate

N. K. Bhatucharyya, Post-Doctoral Fellow

L. Colletti, Graduate Student

G. Vemparala, Graduate Student

V. Vemparala, Graduate Student

Report 8

October, 1991

\begin{abstract}
:
Nitrilotriacetic acid (NTA) is shown to inhibit the thodium-catalyzed evolution of hydrogen from formic acid in low nitrite Purex sludge simulants both by reducing the total amount of hydrogen produced and by lengthening the time period during which hydrogen evolution takes place. Large scale evaluation of NTA as a hydrogen evolution inhibitor is recommended using a 10\% solution of NTA in formic acid in place of the pure formic acid used in the current process.
\end{abstract}




\section{EFFECT OF NITRILOTRIACETIC ACID ON THE RHODIUM CATALYZED EVOLUTION OF HYDROGEN FROM FORMIC ACID IN PUREX SLUDGE SIMULANTS}

Observations at the University of Georgia indicate that shodium is an active catalyst for the decomposition of formic acid to hydrogen and carton dioxide (equation 1)

$$
\mathrm{HCO}_{2} \mathrm{H} \longrightarrow \mathrm{H}_{2}+\mathrm{CO}_{2}
$$

in Purex sludge simulants and that the nitrite ion present in this sludge simulant plays an important role in the catalytic activity of this system. 1,2 This unwanted hydrogen evolution occurs as a sharp "spike" over a relatively shor period of time. ${ }^{3}$ Of imporance is the development of practical methods for inhibiting this unwanted hydrogen evolution or at least to spread this hydrogen evolution over a longer period of time during which the concentration of hydrogen in the off gases can be kept below a dangerous level by dilution methods.

Obvious candidates for inhibitors for this hydrogen evolution include the aminopolycarboxylic acids ethylenediamine tetraacetic acid (EDTA) and nitrilotriaceric acid (VTA) which have the following strictures:

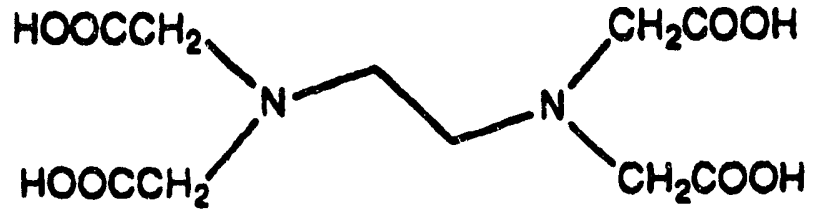

EDTA<smiles>O=C(O)CN(CC(=O)O)CC(=O)O</smiles>

NTA

These aminopolycarboxylic acids, because of their ability to form very stable complexes with noble metals, can inhibit both homogeneous and heterogeneous catalytic activity of noble metuls by the following mechanisms:

Homogeneous: The aminopolycarboxylic acids can till vacant noble metal coordination sites thereby making them unavailable for substrate (e.g., formate) coordination so that homogeneous catalysis cannot take place.

Heterogeneous: Complexation of noble metals with aninopolycurboxylic acids can

'Technical report 4 prepared June,1991

2 Technieal report 5 prepared July, 1991.

3Technicel repon 6 prepared August, 1991. 
inhibit the reduction (e.g., by formic acid) of soluble noble metal compounds to small catalytically active insoluble particles of the free noble metal.

Our initial experiments to evaluate EDTA and NTA as inhibitors for the rhodium-catalyzed hydrogen evolution from formic acid are summarized in Table $1 .^{4}$

\section{Table 1}

Inhibition of Hydrogen Production with Aminopolycarboxylic Acids

All experiments were done with $30 \mathrm{~mL}$ of low nitrite pH 12.0 Purex sludge simulant and $1.6 \mathrm{~mL} 88 \%$ formic acid with $0.056 \mathrm{mmoles} \mathrm{RhCl}_{3} \cdot 3 \mathrm{H}_{2} \mathrm{O}$ at $100 \pm 2{ }^{\circ} \mathrm{C}$.

mmoles additive inmoles additive/Rh $\mathrm{H}_{2}$ tumover/day* $\mathrm{pH}$ at end of expt.

A. Noanditive

$\begin{array}{llll}0 & 0 & 80 & 6.2\end{array}$

B. Ethylenediamine termaceric ucid (EDTA)

$\begin{array}{lccc}0.52 & 6.7 & 85 & 4.8 \\ 0.77 & 13.8 & 35 & 5.7 \\ 1.04 & 18.6 & -0 & 4.0\end{array}$

C. Nimilotriacetic acid (NTA)

$\begin{array}{lccc}0.21 & 3.8 & 90 & 5.0 \\ 0.35 & 6.2 & -0 & 4.7 \\ 0.52 & 9.3 & -0 & 4.7 \\ 0.99 & 17.7 & -1 & 4.7 \\ 1.05 & 18.8 & -0 & 4.3 \\ 1.57 & 28.0 & -0 & 4.3\end{array}$

*The designation " - 0 " means that negligible $\mathrm{H}_{2}$ was produced after waiting $5106 \mathrm{hr}$.

These experiments, which each were run for a period of at least $5 \mathrm{hr}$. suggested that both EDTA and NTA could inhibit the rhodium-catalyzed evolution of hydrogen from formic acid but that NTA was more effective than EDTA possibly because NTA has three

4Technical report 7 prepared September, 1991, and presented at the Weatinghouse Savannah River Laboratory (TNX alto) On October 3, 1991. 
coordinating $\mathrm{CH}_{2} \mathrm{CO}_{2} \mathrm{H}$ "acetic acid arms" bonded to the donor nitrogen atom whereas EDTA has only two coordinating $\mathrm{CH}_{2} \mathrm{CO}_{2} \mathrm{H}$ "acetic acid arms" bonded to each donor nitrögen atom. Under these conditions a NTA/Rh mole ratio as little as a 6.2 appeared to eliminate the rhodium catalyzed hydrogen evolution from formic acid for 5 hours. On the scale used, this corresponds to $0.0668 \mathrm{~g}$. NTA in $1.6 \mathrm{~mL}$ of formic acid or $84.2 \%$ solution of NTA in $88 \%$ formic acid. This preliminary observation suggests that NTA might be a promising candidate to inhibit the rhodium-catalyzed hydrogen evolution from formic acid.

Furcher experiments were carried out to evaluate the following points:

(1) The effect of NTA in the inhibition of the rhodium-catalyzed hydrogen production from formic acid over longer periods of time than 5 to 6 hr.

(2) The effect of NTA on the ruthenium-catalyzed hydrogen production from formic acid since ruthenium is more abundant than rhodium in fission products and since ruthenium-EDTA complexes have been shown by Taqui Khan and coworkers to be active homogeneous catalysts for a number of reactions including the closely related water gas shift reaction (equation 2).5.6

$$
\mathrm{CO}+\mathrm{H}_{2} \mathrm{O} \longrightarrow \mathrm{CO}_{2}+\mathrm{H}_{2}
$$

Table 2 summurizes experiments designed to test these two points whereas Figures 1 and 2 depict the hydrogen evolution as a function of time for the rhodium and ruthenium experiments. respectively, sumuarized in Table 2. Table 2 also shows that palladium (inuroduced as $\mathrm{PdCl}_{2}$ ) is not an active catalyst for the evolution of hydrogen from formic acid in the low-nitrite Purex sludge simulant.

Figure 1 shows the time dependence of hydrogen evolution from formic acid catalyzed by thodium in low nitrite Purex sludge simulant in the presence of various amounts of NT'A over longer periods of time than the initial experiments summarized in Figure 1. The addition of NTA is seen not to suppress completely the evolution of hydrogen over periods of time significantly longer than the 300 minutes used in the preliminary experiments summarized in Table 1. Instead added NTA has the effect of reducing the amount of hydrogen evolution and to spread the hydrogen evolution over a longer period of time. Thus when 1.05 mmoles of NTA is added to the reaction mixture (closed squares in Figure 1) it takes -1450 minutes to produce the same -0.17 mmoles of $\mathrm{H}_{2}$ that is produced in -350 minutes in the absence of any added NTA. The use of 1.05 minoles of NTA $(0.2 \mathrm{~g}$.) in an experiment with $1.6 \mathrm{~mL}$ of $88 \%$ formic acid corresponds to

5M. M. Taqui Khan, S. B. Halligudl, and S. Shukla, Angew. Chem. Int. Ed., 27, 1735 (1988).

6M. M. Taqui Khan. S. B. Halligudi, N. N. Rao, and S. Shukla. J. Mol. Catal., 51, 161 (1989). 
a 12.5\% solution of NTA in formic acid.

Figure 2 shows the effect of NTA on the ruthenium-catalyzed evolution of hydrogen from formic acid. In this case NTA does not appear to inhibit significandy the hydrogen evolution from formic acid catalyzed by ruthenium.

Table 2

Effect of Nitrilotriacetic Acid (NTA) on the Metal-Catalyzed Formic Acid Decomposition in Low Nitrite Purex Sludge Simulants

\begin{tabular}{|c|c|c|c|c|c|c|}
\hline Expt. & netal & moles NTA & $\mathrm{emp},{ }^{\circ} \mathrm{C}$ & $\begin{array}{c}\text { mmoles } \mathrm{H}_{2} \\
\text { at end of } \\
\text { expt. }\end{array}$ & $\begin{array}{l}\text { pH at end of } \\
\text { expe. }\end{array}$ & $\begin{array}{l}\text { wotal } \\
\text { duration } \\
\text { of expl. }\end{array}$ \\
\hline
\end{tabular}

A. $\mathrm{RhCl}_{3} \cdot 3 \mathrm{H}_{2} \mathrm{O}$

$\begin{array}{llcllll}\text { A0 } & 0.056 & 0 & 101 & 0.43 & 6.2 & 500 \mathrm{~min} \\ \text { A1 } & 0.056 & 0.37 & 100 & 0.23 & 5.6 & 548 \mathrm{~min} \\ \text { A2 } & 0.056 & 1.05 & 101 & 0.18 & 6.1 & 1447 \mathrm{~min} \\ \text { A3 } & 0.056 & 1.57 & 99 & 0.10 & 7.5 & 1833 \mathrm{~min}\end{array}$

B. $\mathrm{RuCl}_{3} \cdot 3 \mathrm{H}_{2} \mathrm{O}$

$\begin{array}{llccccc}\text { B1 } & 0.1 & 0 & 100 & 0.38 & 4.3 & 658 \mathrm{~min} \\ \text { B2 } & 0.1 & 1.05 & 100 & 0.35 & 4.7 & 14012 \mathrm{~min} \\ \text { B3 } & 0.1 & 1.57 & 99 & 0.64 & 5.3 & 1589 \mathrm{~min}\end{array}$

C. $\mathrm{PdCl}_{2}$

\begin{tabular}{lllllll} 
C & 0.12 & 0 & 99 & 0 & 4.3 & 1459 min \\
\hline
\end{tabular}

\section{Recommendation}

The experiments outlined in this report indicate that addition of NTA in sufficient quantities can retard significantly the rate of hydrogen evolution from formic acid in low nitrite Purex sludge simulants. The hydrogen evolution data depicted in Figure 1 suggest the evaluation of a $10 \%$ solution of NTA in formic acid as a substituie for pure formic acid in larger scale studies to be perfonned at the TNX site of the Savannah River Laboratory. 
Figure 1

Rhodium Catalyzed Hydrogen Evolution from Formic Acid in Low Nitrite Purex Sludge in the Presence of NTA

(experiments $\mathrm{A} 0, \mathrm{~A} 1, \mathrm{~A} 2$, and $\mathrm{A} 3$ in Table 2)

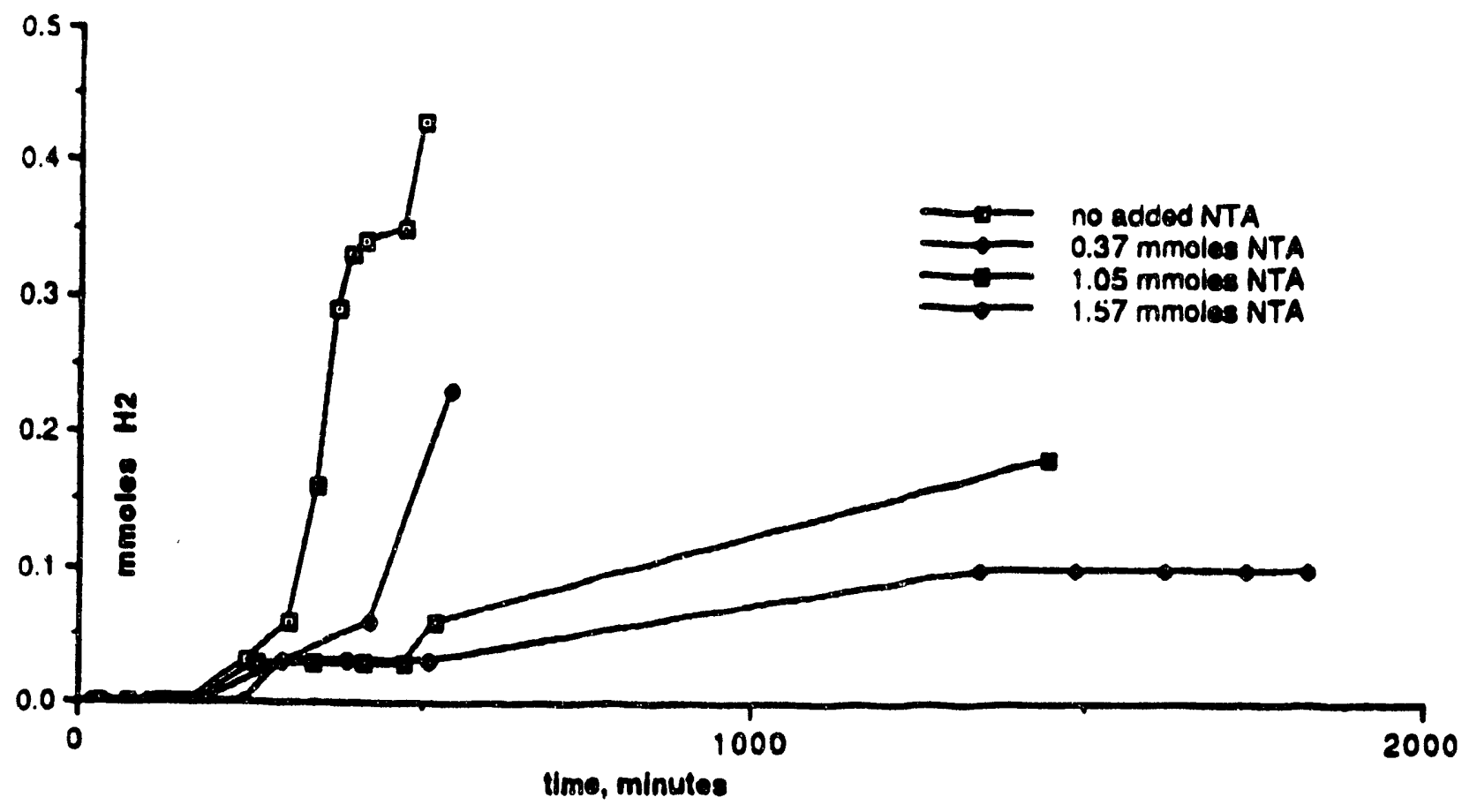


Figure 2

Ruthenium Catalyzed Hydrogen Evolution from Formic Acid in Low Nitrite Purex Sludge in the Presence of NTA

(experiments B1, B2, and B3 in Table 2)

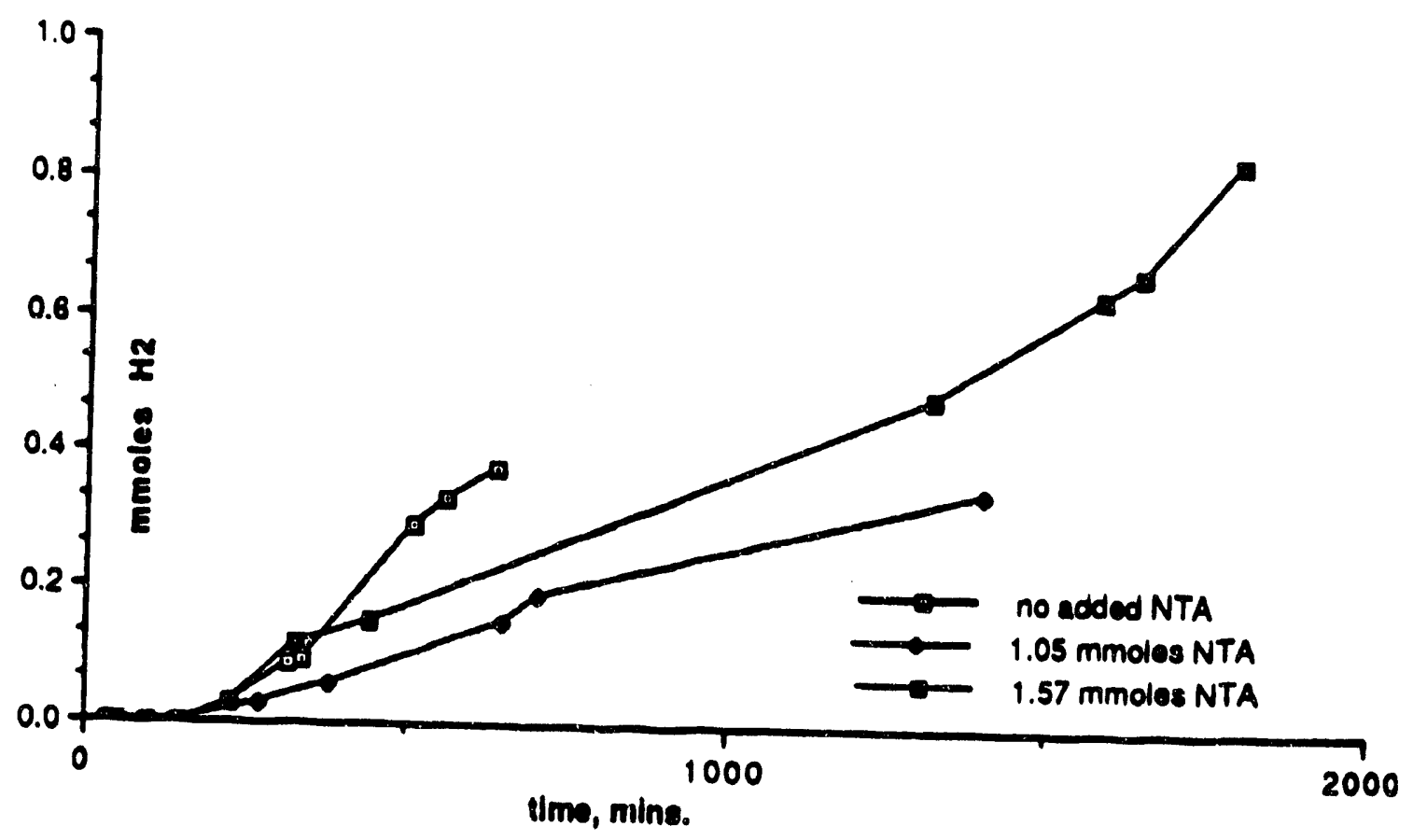




\section{TECHNICAL REPORT}

to the

Westinghouse Savannah River Laboratory

Aiken, South Carolina

on

\section{ELUCIDATION OF NOBLE METAL/FORMIC ACID CHEMISTRY DURING DWPF FEED PREPARATION}

by

R. B. King, Regents' Professor and Principal Investigator

A. D. King, Jr., Professor and Faculty Associate

N. K. Bhattacharyya, Post-Doctoral Fellow

L. Colletti, Graduate Student

G. Vemparala, Graduate Student

Y. Vemparala, Graduate Student

\section{Report 9}

November, 1991

This technical report prepared by Prof. A. D. King, Jr., summarizes some applications of water soluble polymers such as gelatin for controlling the flocculation rate of heterogeneous noble metal catalysts obtained by the reduction of noble metal salts. We propose the investigation of some of these ideas for control of the rate of noble metal catalyzed hydrogen generation from formic acid in the IDMS sludges. 
There are two early papers by Müller 1,2 concerned with the catalytic decomposition of formic acid in solution which may have an important bearing on the future direction of the SRL/TNX research program. Both involve heterogeneous catalysis of HCOOH by solid $\mathrm{Pt}^{1}$ and other transition metals $\mathrm{s}^{2}$ of interest to us such as $\mathrm{Rh}$ and $\mathrm{Ru}$. Both papers note that $\mathrm{H}_{2}$ production commences immediately after the transition metal involved has been reduced to a zero valent state producing a suspension of colloidal particles. Characteristically, the $\mathrm{H}_{2}$ is produced in a short-lived "burst" in which a great deal of $\mathrm{H}_{2}$ is produced over a short ( ${ }_{5} \mathrm{~min}$ ) period of time. However, in both papers, Muller notes that the addition of gelatine suppresses this "burst" of $\mathrm{H}_{2}$ and has the effect of slowing up the initial rate of $\mathrm{H}_{2}$ production while extending the length of time over which $\mathrm{H}_{2}$ is produced. This is illustrated graphically in Fig. 6 of Ref. 2 which shows that the addition of between 0.50 and $5.00 \mathrm{~g}$ of gelatine to $50 \mathrm{cc}$ of a formic acid/formate solution, $\mathrm{pH}=3.1$, has the effect of damping out of the "spike" of $\mathrm{H}_{2}$ production while extending catalytic life of osmium metal particles resulting from the reduction of $\mathrm{K}_{2} \mathrm{OsO}_{4}$. The same effect is found with suspensions of $R u$, Pt. and $I r$, as seen by comparing Fig. 1 with Fig. 7 of ref. 2. Müller concludes that colloidal particles of metal (Os, Ru, Pt, Ir) are responsible for the catalytic decomposition of formic acid. He goes on to invoke a well known aspect of surface and colloid chemistry, the so called "protective colloid effect" to explain the role gelatin plays in damping out the "spike" while extending the catalytic activity of the metals over long periods of time albeit at lower activitles.

Basically, the idea is this, ${ }^{3}$ gelatin and many other high molecular weight polymers, can stabilize colloids, i.e. prevent flocculation from occurring. The common explanation is that the polymers absorb on the surface of the colloid particles and prevent them from approaching close enough to bind with each other, thus preventing the formation of larger "clumps" of particles call "flocs". This particular mode of stabilization is often referred to as "steric stabilization" or as the "protective colloid effect."

It is easy to see how the addition of a polymeric stabilizing agent like gelatin could exert a pronounced effect on rates of reaction which are catalyzed by colloidal metal. since the catalysis occurs at the solution-metal surface, any process that reduces metal-solution surface area will, all else being equal, cause a reduction in the rate of reaction. Flocculation necessarily leads to a reduction in solid-solution surface area so that flocculation has the effect of reducing catalytic activity. One expects, therefore, that the addition of a suspending agent, i.e. a polymer capable of stabilizing colloidal particles, will slow up the rate of flocculation and by doing so act to maintain a colloidal suspension having a high solid-solution surface area. This of course will have the effect of keeping the catalytic activity exhibited by the metal suspension at a high level over long periods of time, as was observed by Müller. 
This observation by Mülier opens up a whole new direction that ought to be pursued in our attempts to ameliorate the effects of $\mathrm{H}_{2}$ generation during sludge digestion.

1. Müller shows that the prolongation of catalytic activity brought on by gelatin occurs at the expense of $\mathrm{H}_{2}$ production rate i.e. the metal suspension maintains catalytic activity for long periods of time but the actual rate of $\mathrm{H}_{2}$ production is much less than that during the "spike" observed in the absence of gelatin. This probably reflects the fact that the adsorbed polymer takes up surface area, thus lessens the rate at which formic acid can adsorb and decompose at the metal-solution interface. This effect in itself is important because a process in which a gradual buildup of $\mathrm{H}_{2}$ occurs is more amenable to intervention by engineering than one in which a rapid evaluation of $\mathrm{H}_{2}$ occurs over a short period of time.

2. There are a number of polymeric materials which, at low concentrations, act to increase the rate of flocculation. These are often referred to as flocculating agents or "clarifiers." Very high molecular weight water soluble polymers tend to be more effective as flocculating agents. Also, polymer concentration plays a significant role in determining the effectiveness of a given polymer acting as a flocculating or as a stabilizing agent. Indeed, the same polymer may act as a flocculating agent at low concentrations and act as a stabilizing agent at high concentrations. Gelatin itself acts to "clarify" suspensions at low concentrations while serving as a stab.lizer at high concentrations such as those employed by Müller. Thus it may be possible to find a polymeric additive that will accelerate the flocculation process in formic acid-sludge mixtures, and by so doing, suppress $\mathrm{H}_{2}$ production entirely.

3. The stabilization of colloids is of course well known to detergent manufacturers and this leads us to a third approach to preventing catalytic decomposition of HCOOH at the solid-solution interface, namely the prevention of the formation of colloidal particles in the first place. Here sequestering agents used as "builders" in household detergents, such as nitrilotriacetic acid (NTA), sodium silicate, or polyphosphates will be added to the sludge prior to the addition of formic acid with the expectation that the transition metal ions will be stabilized with respect to reduction thus preventing the formation of catalytically active colloidal parti.ies of $R h, R u$, etc. It is expected that these sequestering agents will be most effective at $\mathrm{pH} \approx 7$ and that they will be most effective in binding metal ions having high valences, hence exhibit some selectivity towards $\mathrm{Rh}^{+3}$. Indeed, current experiments indicate that NTA does inhibit $\mathrm{H}_{2}$ generation in formic acid-sludge mixtures containing rhodium.

Experiments along the lines outlined above will be carried out in the immediate future. We have ordered and received two samples of a water soluble polymer often used to control flocculation, 
polyacrylic acid. One sample has a low molecular weight $(2000)$ and can be expected to stabilize colloidal particles thus eliminate the spike in $\mathrm{H}_{2}$ production as mentioned in part (1) above. The second sample has a high molecular weight $(250,000)$ and one hopes that it will speed up flocculation, hence decrease $\mathrm{H}_{2}$ production when added to formic acid-sludge mixtures as described in part 2 above. We also purchased another common ingredient in surfactant builders, carboxymethyl cellulose to see if its dispersant action will inhibit flocculation, hence eliminate the "spike" of $\mathrm{H}_{2}$ production in the same manner as the low molecular weight polyacrylic acid mentioned above. Finally, we have received samples of sodium silicate which we will use to extend the studies outlined in part 3 .

There are a number of other water soluble polymers that may prove effective in promoting or stabilizing flocculation in the systems of interest here, the most prominant being polyethylene oxides (PEO). These are nonionic and therefore pH insensitive, and, if time permits, we will examine the effects of high and low molecular weight $P E O$ on $\mathrm{H}_{2}$ production from formic acid sludge systems. 


\section{References:}

1. Müller, E. and Hentschel, H., Ber. 59, 1854 (1926).

2. Müller, E. and Loerpabel, w., Monatsh 53/54, 825 (1929).

3. An excellent discussion concerning the factors that influence Flocculation can be found in: Chapter 11 of "Principles of Colloid and Surface Chemistry, 2nd Ed.. by P. C. Hiemenz, Marcel Dekker, N.Y. 1986. 


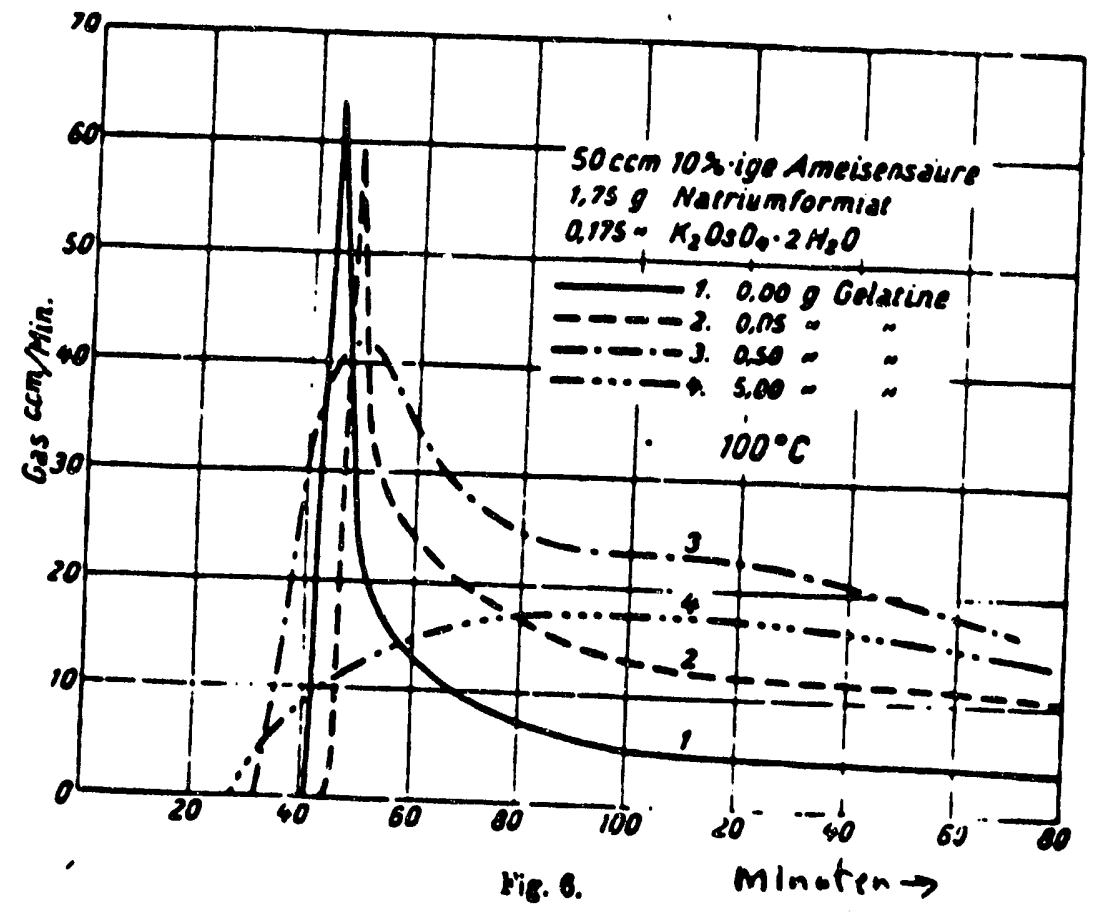

Fig. 6, Muller, E. and Loerpabel, W., Monatsh. 53/54, 825 (1929) 


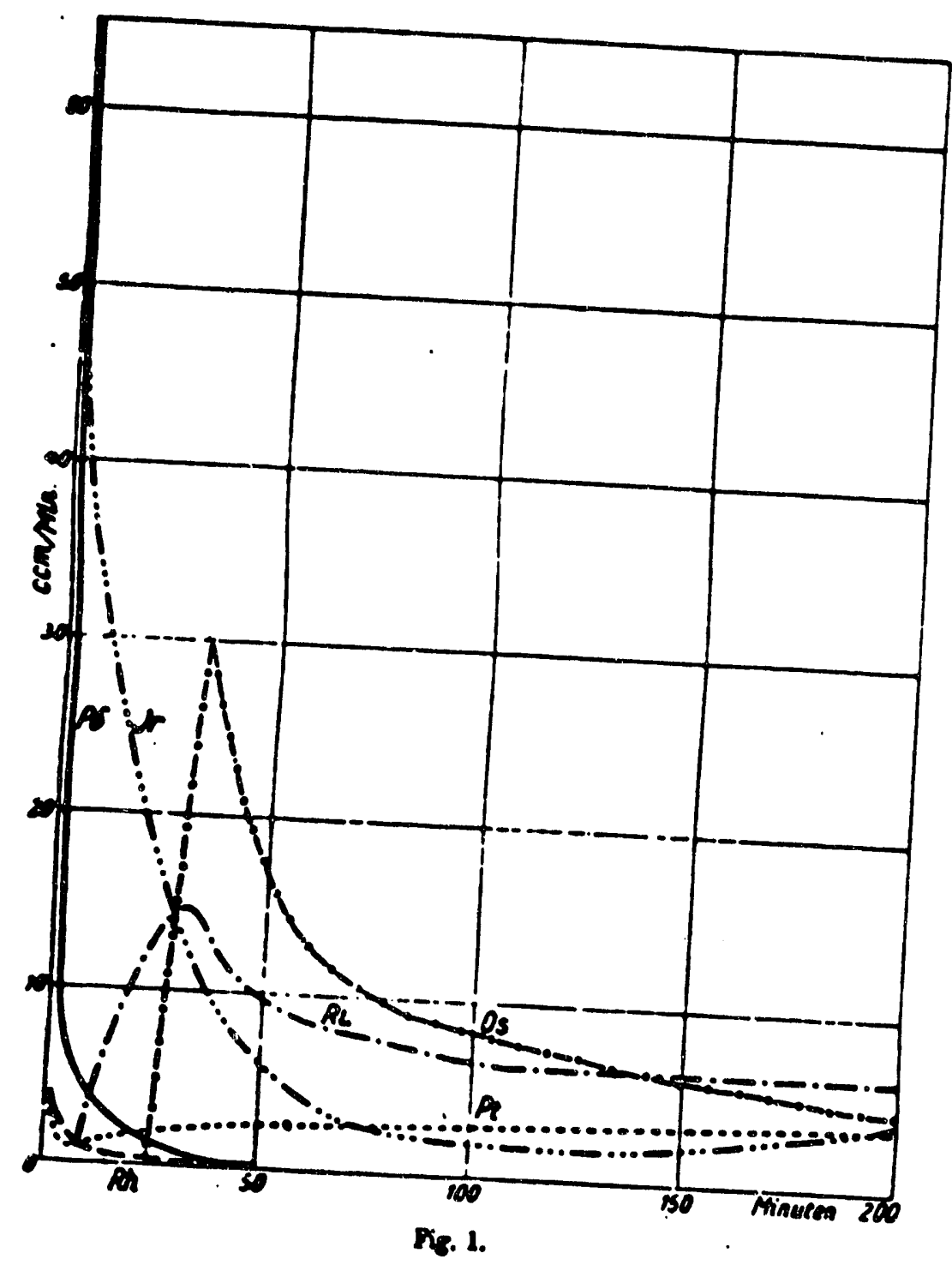

No Gelatin. $\quad T=100 \mathrm{C}$

F1g. 1, Muller, E. and Loerpabel, W., Monatsh. 53/54, 825 (1929) 


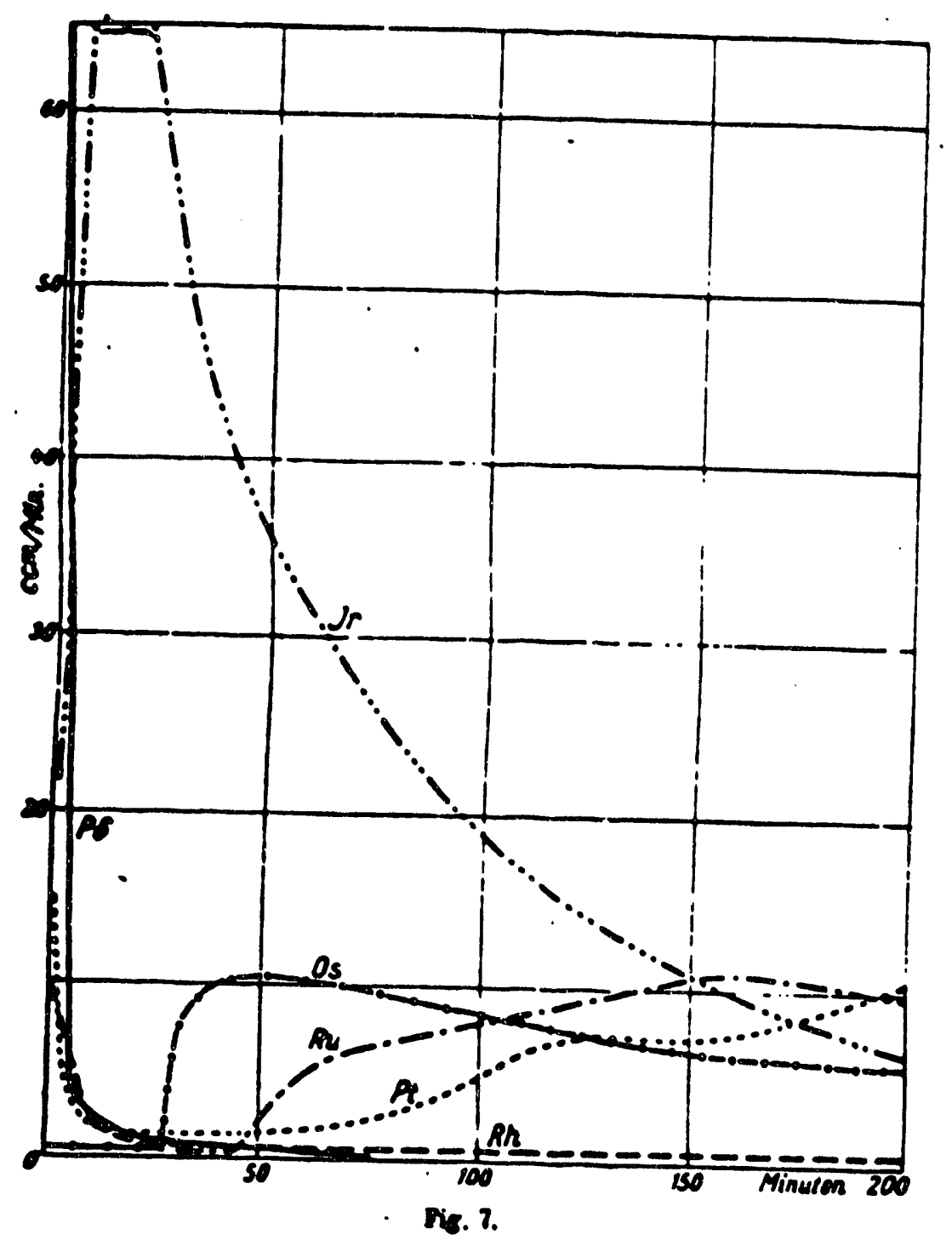

1 Gram Gelatin per $50 \mathrm{~mL}$. $T=100 \mathrm{C}$

Fig. 7, Muller, E. and Loerpabel, W., Monatsh. 53/53, 825 (1929) 


\section{TECHNICAL REPORT}

to the

Westinghouse Savannah River Laboratory

Aiken, South Carolina

on

\section{ELUCIDATION OF NOBLE METAL/FORMIC ACID CHEMISTRY DURING DWPF FEED PREPARATION}

by

R. B. King, Regents' Professor and Principal Investigator

A. D. King, Jr., Professor and Faculty Associate

N. K. Bhattacharyya, Post-Doctoral Fellow

L. Colletti, Graduate Student

G. Vemparala, Graduate Student

V. Vemparala, Graduate Student

Report 10

December, 1991

\section{Abstract}

The catalytic activities of the three noble metals rhodium, ruthenium, and palladium for the evolution of hydrogen from formic acid are compared in Purex and HM sludge simulants containing various amounts of nitrite including a nitrite-free sludge simulant. All three noble metals are catalytically active for hydrogen evolution but in different regimes. Rhodium appears to require nitrite for significant catalytic activity in the sludge simulant media. However, the catalytic activity of ruthenium is high only in the absence of nitrite so that nitrite is a strong inhibitor for the ruthenium-catalyzed formic acid decomposition. Preliminary experiments suggest that the catalytic activity of palladium is promoted by the addition of chloride and is relatively insensitive to the presence of nitrite. 


\section{EFFECT OF NITRITE ON THE NOBLE METAL CATALYZED EVOLUTION OF HYDROGEN FROM FORMIC ACID IN SLUDGE SIMULANTS}

The three noble metals ruthenium, rhodium, and palladium are important components in high level nuclear waste. Each metal has the potential of catalyzing the decomposition of formic acid to hydrogen and carbon dioxide according to the following equation':

$\mathrm{HCO}_{2} \mathrm{H} \longrightarrow \mathrm{H}_{2}+\mathrm{CO}_{2}$

Previous work suggested that, of these three noble metals, rhodium was most active in catalyzing formic acid decomposition and that the catalytic activity of rhodium was promoted by the addition of nitrite. ${ }^{2}$ However, until recently no experiments had been performed to establish the role of nitrite in actual sludge simulants because no nitrite-free samples of sludge simulants were available.

Several weeks ago a sample of nitrite-free sludge simulant was obtained from Westinghouse Savannah River Laboratory (WSRL/TNX), who in turn had procured it from their contractor. The composition of this sludge simulant was checked by the analytical laboratory of WSRL. Table 1 compares the composition of this nitrite-free sludge simulant with that of the Purex sludge simulant used in most of the experiments summarized in Technical Reports 5 through 8. We have studied the formic acid decomposition reaction catalyzed by rhodium, ruthenium, and palladium in the presence of this sludge simulant. This report compares the catalytic activity for formic acid decomposition (equation 1) of these three noble metals in the nitrite-free sludge simulant with that found with the earlier nitrite-containing sludge simulants (Purex and HM). The catalytic activity of these metals is found to be quite different in the presence of this nitritefree sludge when compared with earlier results obtained with the original Purex and HM sludges. In order to evaluate whether differences in the sludge simulant compositions other than the presence or absence of nitrite are responsible for the observed differences in catalytic activity, experiments have also been performed in which known amounts of nitrite have been added to the nitrite-free sludge simulant immediately before carrying out the catalytic experiments.

\footnotetext{
1 Technical Report 1 to WSRL on Elucidation of Noble Metalformic Acid Chemistry During DWPF Feed Preparation prepared March, 1991.

2Technical Report 5 to WSRL on Elucidation of Noble MetaVFormic Acid Chemistry During DWPF Feed Preparation prepared July, 1991.
} 


\section{Experimental Section}

The reactions were carried out in $250 \mathrm{~mL}$ glass vessels equipped with a threaded outlet with an O-ring adapter. A pressure gauge was attached to the system via a side arm. The other two side arms near the top were capped with rubber septa through which needles could be inserted to flush the system or for gas sampling. The reaction vessels have two wells. In one well a thermocouple attached to a cyclic heater was placed to maintain a constant temperature. The other well was used to double check the temperature of the reaction mixture by a digital readout thermometer.

In all of the experiments $30 \mathrm{~mL}$ of sludge simulant was used. To this sludge simulant was added either $10 \mathrm{~mL}$ of the noble metal chloride solution or the desired amount of the noble metal compound and $10 \mathrm{~mL}$ of water. At this stage a measured amount of additional solid sodium nitrite was added in some experiments. The contents of the reaction vessel were then treated with $1.6 \mathrm{~mL}$ of $88 \%$ formic acid. The system was then stoppered and flushed with argon to remove all air. The flask was then heated to $\sim 100^{\circ}$ and gas samples were taken periodically and analyzed by the standard gas chromatographic procedure. 1

The results of these experiments are summarized in Table 2. Plots of hydrogen evolution versus time for the experiments using rhodium, ruthenium, and palladium chlorides are given in Figures 1, 2, and 3, respectively.

\section{Results and Discussion}

\section{A. Acid titration studies (Table 3)}

Sodium nitrite, being the salt of a strong base $(\mathrm{NaOH})$ and a weak acid $\left(\mathrm{HNO}_{2}\right)$, exhibits basic properties in aqueous solution. For this reason the amounts of sodium nitrite in the sludge simulant is expected to affect the $\mathrm{pH}$ attained upon treatment with formic acid. Table 3 summarizes the $\mathrm{pH}$ values obtained when the five sludge simulants used in the experiments summarized in Table 2 are treated with the same amount of formic acid. As expected, larger amounts of added sodium nitrite lead to higher $\mathrm{pH}$ values. However, the $\mathrm{pH}$ differences before heating and in the absence of catalytic formic acid decomposition do not appear to be large enough to have a significant effect on the relevant noble metal chemistry.

\section{B. Rhodium experiments}

The results summarized in Table 2 and depicted in Figure 1 confirm the role of 
nitrite ion as a promoter of the rhodium-catalyzed decomposition of formic acid in sludge simulant media. In all of the rhodium experiments hydrogen was produced in a relatively short "burst" and essentially no additional hydrogen was produced after the first $-2 \mathrm{hr}$ $(\sim 120 \mathrm{~min})$. The amount of hydrogen produced in the initial "burst" was relatively small ( $0.44 \mathrm{mmol})$ in the absence of nitrite but increased consistently as increasing amounts of nitrite were added to the system. The profile of hydrogen evolution versus time in the experiment using the Purex sludge simulant is almost identical to that of the experiment using the nitrite-free sludge simulant with $625 \mathrm{mg}$ added sodium nitrite.

\section{Ruthenium experiments}

Experiments summarized in previous technical reports ${ }^{3}$ indicate negligible catalytic activity of ruthenium trichloride for formic acid decomposition (equation 1) in the IDMS sludge simulant, which is $-0.3 \mathrm{M}$ in nitrite. However, the results summarized in Table 2 and depicted in Figure 2 indicate that in the nitrite-free sludge ruthenium is a more active catalyst for formic acid decomposition than rhodium in the presence of nitrite. Furthermore, nitrite is seen in Figure 2 to be a strong inhibitor for the evolution of hydrogen from formic acid catalyzed by ruthenium. The inhibition of the catalytic activity of ruthenium by addition of nitrite may be a consequence of the formation of catalytically inactive ruthenium nitrosyl derivatives. We plan to test this hypothesis by experiments in which ruthenium is added as ruthenium nitrosyl nitrate rather than ruthenium chloride; we have a sample of ruthenium nitrosyl nitrate on hand for this purpose.

\section{Palladium experiments}

Experiments summarized in previous technical reports ${ }^{3}$ indicate that palladium is only about $\sim 10 \%$ as active as rhodium in the high-nitrite HM sludge simulant. The experiments summarized in Table 2 and depicted in Figure 3 indicate that palladium is quite active as a catalyst for formic acid decomposition in the presence of nitrite-free sludge simulant. Furthermore, this high catalytic activity of palladium is not inhibited significantly by addition of nitrite to the nitrite-free sludge simulants (Figure 3). This is in marked contrast to recent results which confirm the previous result that palladium is relatively inactive towards formic acid decomposition in nitrite-containing Purex and HM sludge simulants (Table 2). Analytical data indicate the nitrite-free sludge simulant to be unusually high in chloride (Table 1) possibly because, in the absence of sodium nitrite, sodium

\footnotetext{
3Technical Report 4 to WSRL on Elucidation of Noble MetaVFormic Acid Chemistry During DWPF Feed Preparation prepared June, 1991.
} 
chloride was added to maintain the required quantity of sodium in the preparation of the nitrite-free sludge. We thus suspect that chloride might be a promoter of the catalytic activity of palladium, possibly either by forming $\mathrm{PdCl}_{4}{ }^{2-}$ and related chloropalladium complexes or by stabilizing colloidal palladium metal. We plan to test this hypothesis by experiments in which chlorite is added to the nitrite-containing Purex and HM sludge simulants before carrying out catalytic reactions using palladium chloride.

\section{Summary and Recommendations}

The experiments outlined in this report indicate that all three noble metals found in nuclear fission wastes (ruthenium, rhodium, and palladium) are catalytically' active for hydrogen zvolution from formic acid under certain conditions. In the Purex and HM sludge simulants, which contain substantial amounts of nitrite but only minor amounts of chloride, rhodium is clearly the most active of the three noble metals. Suppression of undesirable hydrogen evolution in these systems consists of finding an acceptable way to inhibit this unwanted rhodium catalytic activity possibly by addition of a complexing agent to tie up the rhodium coordination sites needed for the catalytic process. Nitrilotriacetic acid, $\mathrm{N}\left(\mathrm{CH}_{2} \mathrm{CO}_{2} \mathrm{H}\right)_{3}$, is an example of a metal complexing agent which appears to show some promise as an inhibitor of this rhodium catalytic activity. ${ }^{4}$

A suggestion from the previous work on the role of nitrite as a promoter of the rhodium catalyzed hydrogen evolution from formic acid is the reduction of the catalytic activity of the rhodium by chemical removal of nitrite from the sludge. The work summarized in this proposal suggests that this approach would be unpromising. Thus although removal of nitrite from the sludge might serve to eliminate significant catalytic activity of the rhodium present, it would concurrently increase even more drastically the catalytic activity of the larger amounts of ruthenium present.

The results in this report also suggest a possible role of chloride in the noble metal catalyzed evolution of hydrogen from formic acid. Thus preliminary work suggests that palladium is a very active catalyst for hydrogen evolution from formic acid in the presence of chloride. If feeds containing significant amounts of chloride are to be processed in the DWPF plant, then we may need to learn how to inhibit the decomposition of formic acid catalyzed by palladium as well as rhodium.

The results discussed in this report suggest at least two principal regimes for the noble metal catalyzed decomposition of formic acid (equation 1) in the nitrite-containing

\footnotetext{
${ }^{4}$ Technical Repon 8 to WSRL on Elucidation of Noble MetalFormic Acid Chemistry During DWPF Feed Preparation prepared October, 1991.
} 
sludge simulants in the presence of all three noble metals of interest in the open systems studied at W'SRLTNX. Initially in the presence of nitrite rhodium is the active metal. However, in an open system nitrite is removed by reaction with acid according to the following equation:

$$
3 \mathrm{NO}_{2}^{-}+3 \mathrm{H}^{+} \longrightarrow 3 \mathrm{HNO}_{2} \longrightarrow 2 \mathrm{NO}+\mathrm{NO}_{3}^{-}+\mathrm{H}^{+}+\mathrm{H}_{2} \mathrm{O}
$$

As the nitrite is removed by this process the catalytic activity of rhodium for formic acid decomposition subsides. This is also in accord with the observation that the rhodium catalyzed evolution of hydrogen in the experiments depicted in Figure 1 stops after approximately $2 \mathrm{hr}$. after substantial nitrite has been removed by the process indicated in equation 2 as indicated by the presence of substantial amounts of nitric oxide in the gas phase. However, a second phase of hydrogen production can start at relatively late reaction times when so much nitrite is removed that ruthenium becomes catalytically active. 
Table 1

Comparison of the Compositions of the Purex Sludge and the Nitrite-Free Sludge Simulants Used in this Work

Component Low-nimite Punex Sludge Nonimite Sludge

pH $11.1 \quad 11.4$

A. Inductively Coupled Plasma and Atomic Absorption, weight \%

$\begin{array}{ccc}\mathrm{Al} & 6.4 & 12.8 \\ \mathrm{Ba} & 0.5 & 0.2 \\ \mathrm{~B} & 0.01 & 0.01 \\ \mathrm{Ca} & 3.3 & 2.2 \\ \mathrm{Cr} & 0.01 & 0.04 \\ \mathrm{Cu} & 0.19 & 0.03 \\ \mathrm{Fe} & 22.3 & 19.4 \\ \mathrm{~Pb} & 1.0 & 0.2 \\ \mathrm{Mg} & 0.1 & 0.4 \\ \mathrm{Mn} & 8.0 & 6.6 \\ \mathrm{Nd} & 0.35 & 0.6 \\ \mathrm{Ni} & 4.3 & 1.0 \\ \mathrm{P} & 0.13 & 0.4 \\ \mathrm{~K} & 0.7 & 0.2 \\ \mathrm{Na} & 3.6 & 1.7 \\ \mathrm{Si} & 2.6 & 3.8 \\ \mathrm{Sr} & 0.05 & 0.35 \\ \mathrm{Ti} & 0.005 & <0.01 \\ \mathrm{Zn} & 0.5 & 0.06 \\ \mathrm{Zr} & 0.002 & <0.01\end{array}$

B. Ions by Ion Chromatography in Supernatant Liquid, $\mathrm{mg} / \mathrm{L}$

$\begin{array}{ccc}\mathrm{Cl}^{-} & -0 & 4500 \\ \mathrm{NO}_{3}^{-} & 660 & 610 \\ \mathrm{NO}_{2}^{-} & 3300 & 12 \\ \mathrm{C}_{2} \mathrm{O}_{4}^{2-} & -0 & 29 \\ \mathrm{SO}_{4}^{2-} & 1500 & 1400\end{array}$


Table 2

Studies on the Noble Metal Catalyzed Formic Acid Decomposition in Sludge Simulants Containing Variable Amounts of Nitrite

\begin{tabular}{|c|c|c|c|c|c|c|c|}
\hline $\begin{array}{l}\text { Sludge } \\
\text { Type }\end{array}$ & $\begin{array}{c}\mathrm{NaNO}_{2} \\
(\mathrm{mg})\end{array}$ & $\underset{\text { Temp. }}{\text { Temp. }}$ & $\begin{array}{c}\mathrm{H}_{2} \\
\text { turnover, } \\
\text { day }\end{array}$ & $\begin{array}{c}\text { Duration } \\
\text { of expt. } \\
\text { (min) }\end{array}$ & $\begin{array}{l}\mathrm{mmol} \mathrm{H} \\
\text { (end of } \\
\text { expr.) }\end{array}$ & $\begin{array}{l}\text { pH } \\
\text { (end of } \\
\text { expt.) }\end{array}$ & $\begin{array}{c}\text { Color } \\
\text { (end of expt) }\end{array}$ \\
\hline \multicolumn{8}{|c|}{ A. $\mathrm{PdCl}_{2}(0.04 \mathrm{mmol})$ added: } \\
\hline no nitrite & 0 & 100 & 450 & 490 & 4.21 & 3.2 & green-white \\
\hline no nitrite & 125 & 101 & 90 & 339 & 0.67 & 3.2 & black \\
\hline no nitrite & 625 & 99 & 300 & 464 & 3.29 & 3.7 & black \\
\hline Purex & 0 & 97 & -0 & 1400 & 0.09 & 4.9 & red-brown \\
\hline HM & 0 & 95 & -0 & 450 & 0.09 & 5.7 & black \\
\hline \multicolumn{8}{|c|}{ B. $\mathrm{RuCl}_{3}(0.06 \mathrm{mmol})$ added: } \\
\hline no nitrite & 0 & 100 & 900 & 1452 & 6.00 & 3.7 & $\tan$ \\
\hline no nitrite & 125 & 100 & high & 1440 & $-30 \%$ volc & 3.6 & yellow-tan \\
\hline no nitrite & 625 & 100 & 20 & 1881 & 1.14 & 3.7 & ycllow-brown \\
\hline Purex & 0 & 100 & 10 & 5672 & 0.69 & 5.5 & brown \\
\hline $\mathrm{HM}$ & 0 & 98 & 35 & 1761 & 1.44 & 4.3 & brown \\
\hline \multicolumn{8}{|c|}{ C. $\mathrm{RhCl}_{3}(0.06 \mathrm{mmol})$ added: } \\
\hline no nitrite & 0 & 98 & d & 1842 & 0.44 & 3.1 & black \\
\hline no nitrite & 125 & 97 & d & 429 & 0.67 & 3.3 & gray-white \\
\hline no nitrite & 625 & 93 & d & 437 & 2.90 & 3.8 & green-white \\
\hline Purex & 0 & 98 & 90 & 375 & 1.00 & 6.3 & brown-black \\
\hline HMM & 0 & 99 & & 450 & $50 \%$ volc & 6.7 & dark brown \\
\hline
\end{tabular}

aThe Purex sludge simulant is $-0.06 \mathrm{M}$ in nitrite; the HM sludge is $-0.3 \mathrm{M}$ in nitrite. bThese turnover numbers were estimated from the slope of the mmoles $\mathrm{H}_{2}$ versus time plot during the period of steady hydrogen evolution.

cBecause of leakage problems arising from the large amount of hydrogen produced, the exact amount of hydrogen present at the end of the experiment could not be determined. dAfter an initial burst of hydrogen, almost no further hydrogen was produced. 
Table 3

Effect on pH by Adding Formic Acid to Various Sludge Simulants

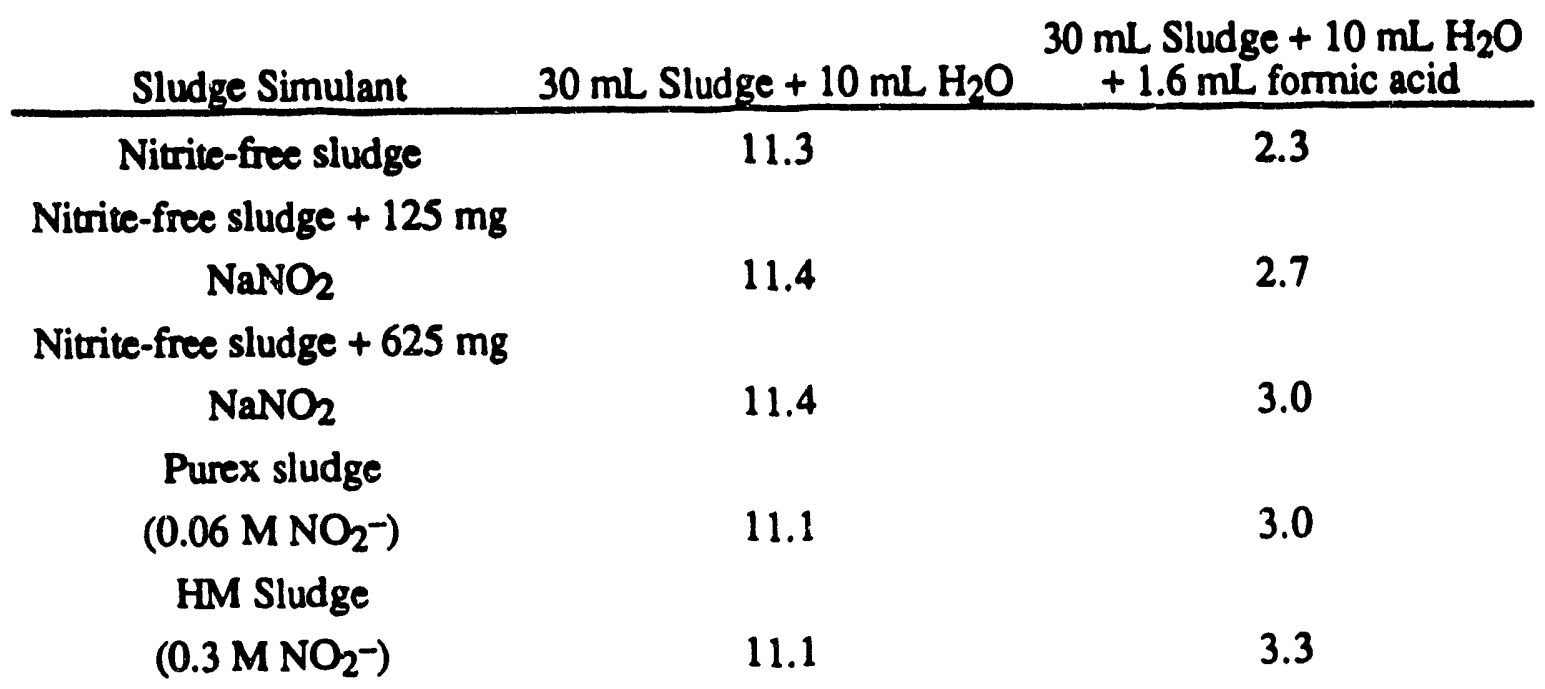

Figure 1

Sludge experiments with added rhodium chloride (0.06 mmol)

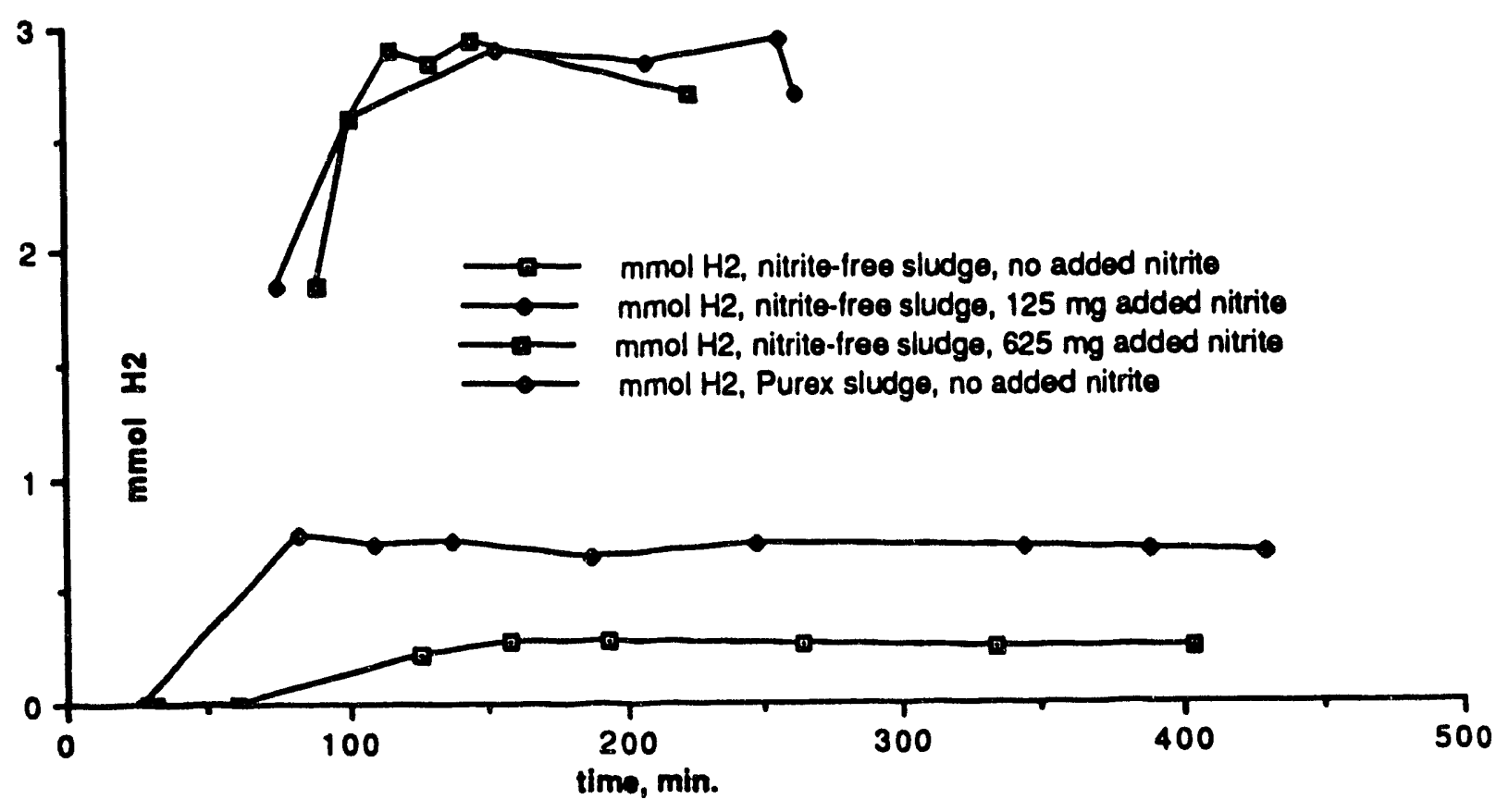




\section{Figure 2}

Sludge experiments with added ruthenium chloride (0.06 mmol)

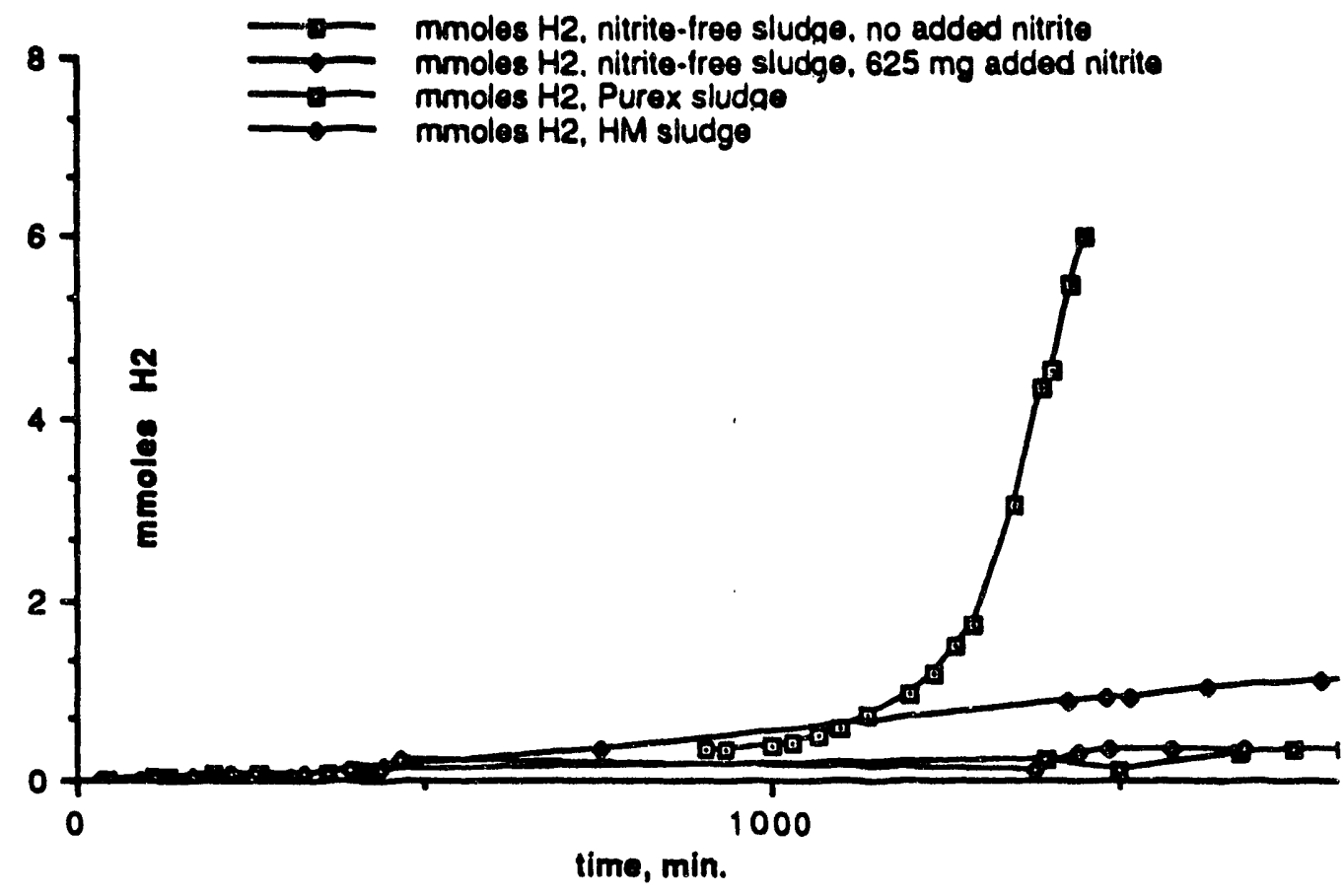

Figure 3

Nitrite-free sludge experiments with added palladium chloride $(0.04 \mathrm{mmol})$

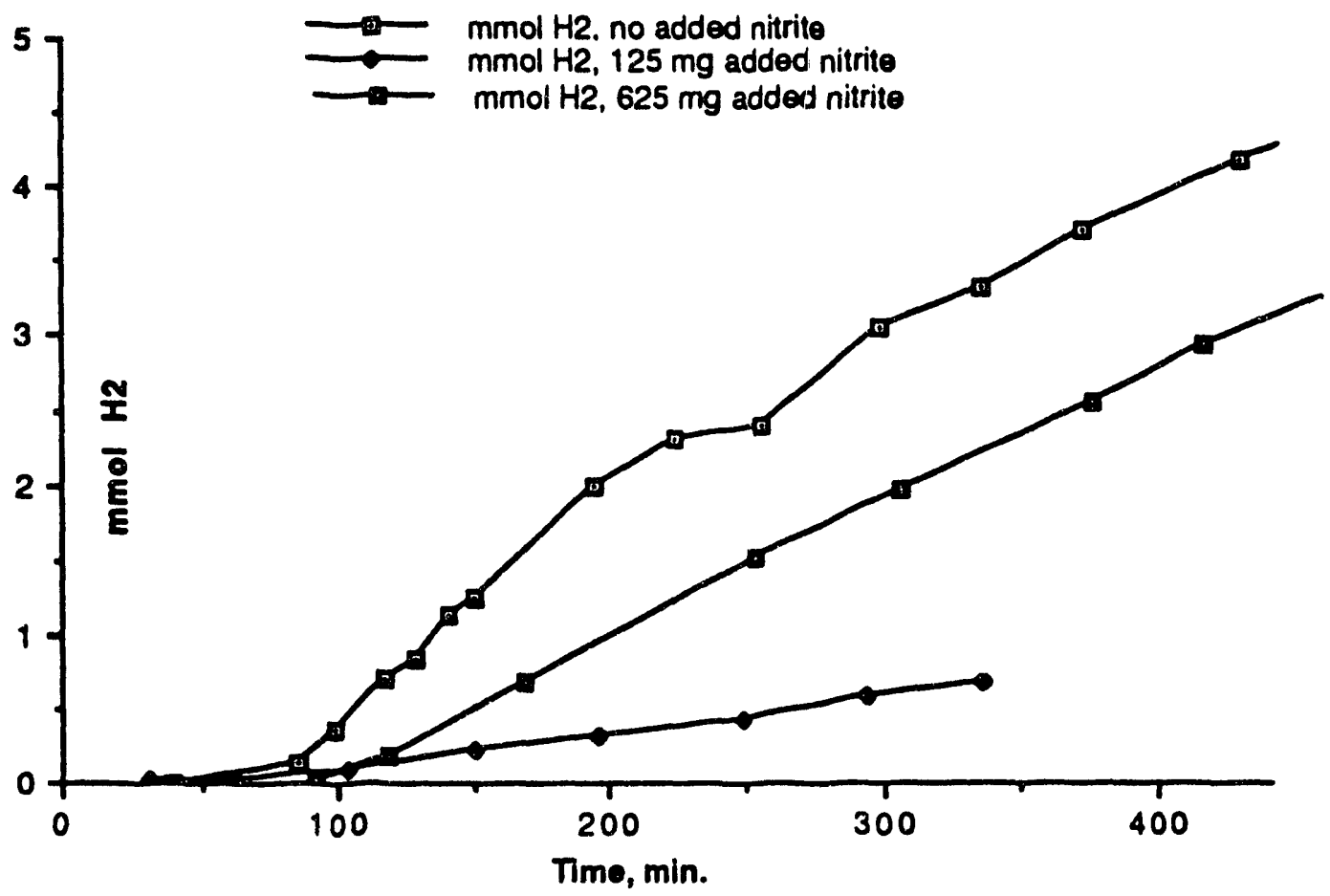




\title{
TECHNICAL REPORT
}

to the

Westinghouse Savannah River Laboratory

Aiken, Soudr Carolina

on

\section{ELUCIDATION OF NOBLE METAL/FORMIC ACID CHEMISTRY DURING DWPF FEED PREPARATION}

by

R. B. King, Regents' Protessor and Principal Investigator

A. D. King, Jr., Professor and Faculty Associate

N. K. Bhattacharyya, Post-Doctoral Fellow

L. Colletti, Graduate Student

G. Veinparala, Graduate Student

V. Vemparala, Graduate Student

Report 11

January, 1992

\begin{abstract}
Experiments are reported relating to the hrogeneous versus heterogeneous nature of the rhodium catalyst for the decromposition of formic acid to carbon dioxide and hydrogen. Thus sodium tripolypitosphate did not inhibit significantly the rhodiumcatalyzed generation of hydrogen from fornic acid in the presence of low nitrite Purex sludge simulant. Sodium siiicate. sodium carboxymethylcellulose, and polyacrylic acid samples of molecular weights 250,000 and 2,000 showed some tendency to inhibit hydrogen production in this system bu: not enough to be usetul as practical inhibitors. In an ideal system rathen than an actual sludge simulant addition of solid aluminum cxide to rhodium trichioride generated an active catalyst for formic acid decomposition even in the absence of added nitrite. However, iron oxide and silicon dioxide did not promote the catalytic activity of thodium chloride in the absence of nitrite.
\end{abstract}


The Effect of Water-Soluble Polymers on the Activity of Rhodium Catalysts for Formic Acid Decomposition (N. K. Bhattacharyya)

A previous technical report ${ }^{1}$ suggested the use of water-soluble polymers for controlling the flocculation rate of heterogeneous noble metal catalysts obtained by the reduction of noble metal sults. Thus the addition of a polymeric stabilizing agent could exert a pronounced effect on rates of reaction which are catalyzed by colloidal metal. This idea was tested experimentally by using the following water-soluble polymers:

(1) Sodium tripolyphosphate.

(2) Aqueous sodium silicate solution containing $14 \% \mathrm{NaOH}$ and $27 \% \mathrm{SiO}_{2}$.

(3) Sodium carbomethoxycellulose.

(4) Polyacrylic acids of inolecular weights 2,000 and 250,000.

In all cases experiments were performed using $30 \mathrm{~mL}$ of the low nitrite Purex sludge simulant $(0.06 \mathrm{M}$ in nitrite), $10 \mathrm{~mL}$ of a $1.4 \mathrm{mg} / \mathrm{mL}$ solution of rhodium trichloride, and $1.6 \mathrm{~mL}$ of $88 \%$ formic acid at $100 \pm 2^{\circ} \mathrm{C}$ (except for the sodium silicate experiments which were performed at $94 \pm 2^{\circ} \mathrm{C}$ ). Representutive results for each of the additives are plotted in Figure 1. Hydrogen production was most rapid in the experiment using sodium tripolyphosphate as an additive. The other three additives exhibited some tendency to slow the rate of hydrogen production but not enough to be of interest as practical inhibitors.

\section{Effect of Solid Oxides on Hydrogen Generation (Lisa Colletti)}

The sludge simulants consist of a mixture of insoluble metal hydroxides/oxides with $\mathrm{Al}_{2} \mathrm{O}_{3}$ and $\mathrm{Fe}_{2} \mathrm{O}_{3}$ as major components. Experiments were performed in order to assess the role of these insoluble inetal hydroxides/oxides on hydrogen generation using "ideal" systems consisting of $1.5 \mathrm{~mL}$ of formic acid, $35.5 \mathrm{~mL}$ of water, 0.077 mmoles of rhodium trichloride dissolved in $3 \mathrm{~mL}$ of water, and 0.311 minoles of the solid oxide (31.7 $\mathrm{mg}$ of $\mathrm{Al}_{2} \mathrm{O}_{3}, 49.7 \mathrm{mg}$. of $\mathrm{Fe}_{2} \mathrm{O}_{3}$, or $18.7 \mathrm{mg}$ of silica gel) at $97 \pm 1^{\circ} \mathrm{C}$. Experiments were done both in the absence of nitrite and in the presence of 0.311 mmoles of $\mathrm{NaNO}_{2}$ dissolved in $2.1 \mathrm{~mL}$ of water. The results are plotted in Figure 2.

The observations froin these experimenes can be summarized as follows:

(1) Substantial hydrogen evolution as a sudden burst followed by leveling off was observed in the presence of nitrite regardless of the solid oxide present. This is consistent

\footnotetext{
1 Technical Report 9 to WSRL on Elucidation of Noble MetalfFormic Acid Chemistry during DWPF Feed Preparation prepared November, 1991.
} 
with previous reports on the role of nitrite in promoting the rhodium-catalyzed decomposition of fornic acid. ${ }^{2}$

(2) Substantial but gradual hydrogen evolution occurred in the presence of alumina even in the absence of nitrite. The role of the rhodium catalyst in hydrogen generation from formic acid in the presence of alumina was confirmed by a control experiment in which a mixture of $31.7 \mathrm{mg} \mathrm{Al} \mathrm{O}_{3}$ (0.311 mmoles), $1.5 \mathrm{~mL}$ of $88 \%$ formic acid, and 38.5 $\mathrm{mL}$ of water was shown to give negligible amounts of hydrogen upon heating to $96 \pm 2^{\circ} \mathrm{C}$ in the absence of any added rhodium.

(3) Hydrogen evolution in the presence of iron oxide or silica gel in the absence of nitrite was negligible.

These results thus indicate that either nitrite or alumina promote the catalytic activity of rhodium for the decomposition of formic acid to hydrogen. However, the different patterns of hydrogen evolution suggest the possibility of different mechanisms for each of these two types of promoters.

A previous technical report ${ }^{3}$ discusses the possibility of either homogeneous or heterogeneous catalysis for the rhodium-catalyzed decomposition of formic acid to give hydrogen. Our current observations may provide examples of both types of behavior. Thus the sudden burst of hydrogen in the nitrite-promoted rhodium systems may arise from an active homogeneous nitrorhodium catalyst which has a limited lifetime under the actual reaction conditions. On the other hand the gradual evolution of hydrogen in the presence of alumina may arise from heterogeneous particles of metallic rhodium which are prevented from aggregating into catalytically inactive bulk rhodium metal by the alumina surface.

2Technical Report 5 to WSRL on Elucidation of Noble MetalfFormic Acid Chemistry during DWPF Feed Preparation prepared July, 1991.

3Tochnical Report 6 to WSRL on Elucidation of Noble Metal/Formic Acid Chemistry during DWPF Feed Preparation prepared August, 1991. 
Figure 1

Low Nitrite Purex Sludge, $30 \mathrm{~mL}$; Rhodium Trichloride, $14 \mathrm{mg}$;

$1.6 \mathrm{~mL} 88 \%$ formic acid

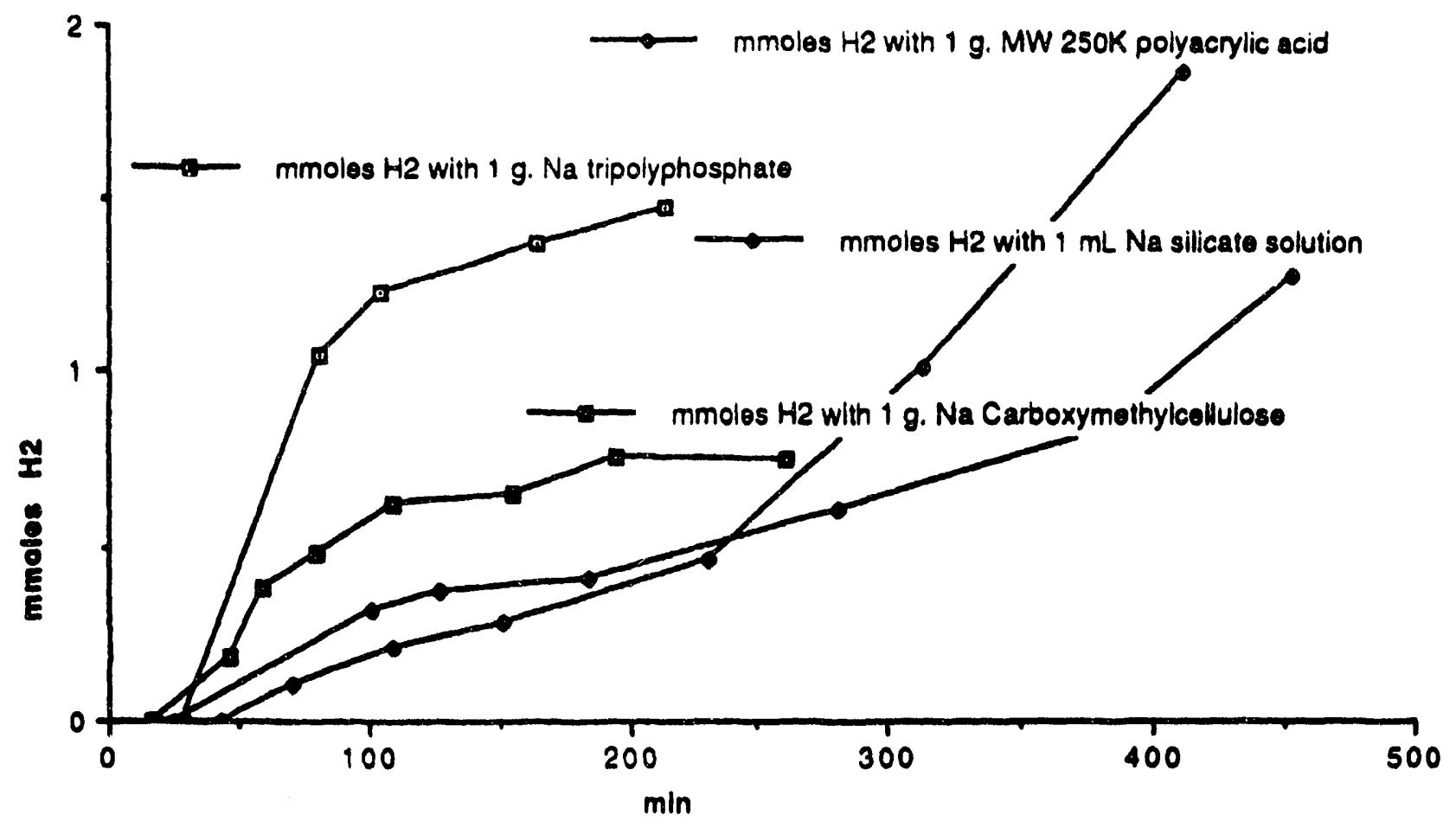


Figure 2

Effect of Solid Oxides and Nitrite on Hydrogen Generation from Formic Acid $0.077 \mathrm{mmol}$ Rh, $1.5 \mathrm{~mL} 88 \%$ formic acid, $35.5 \mathrm{~mL}$ water

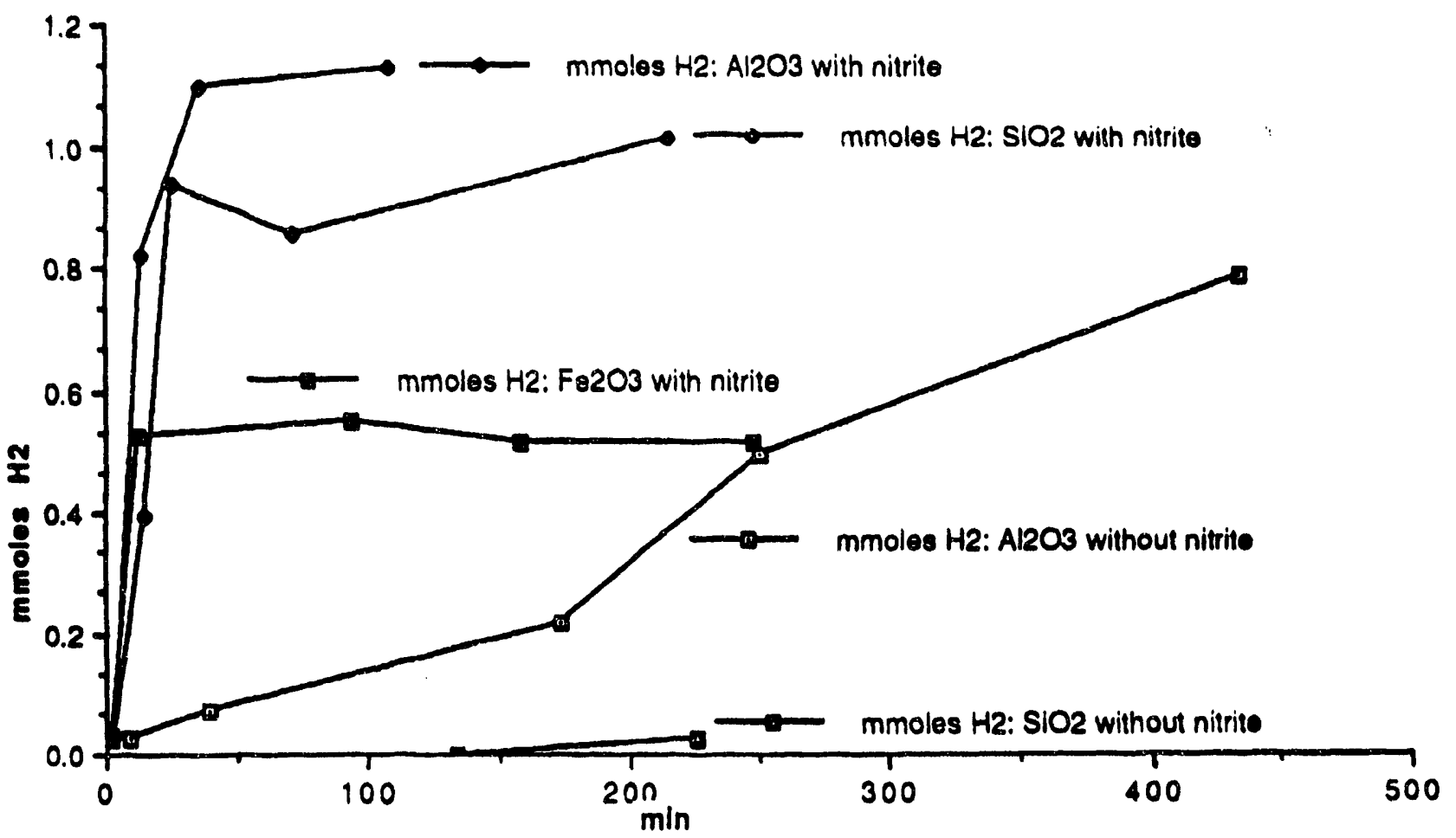



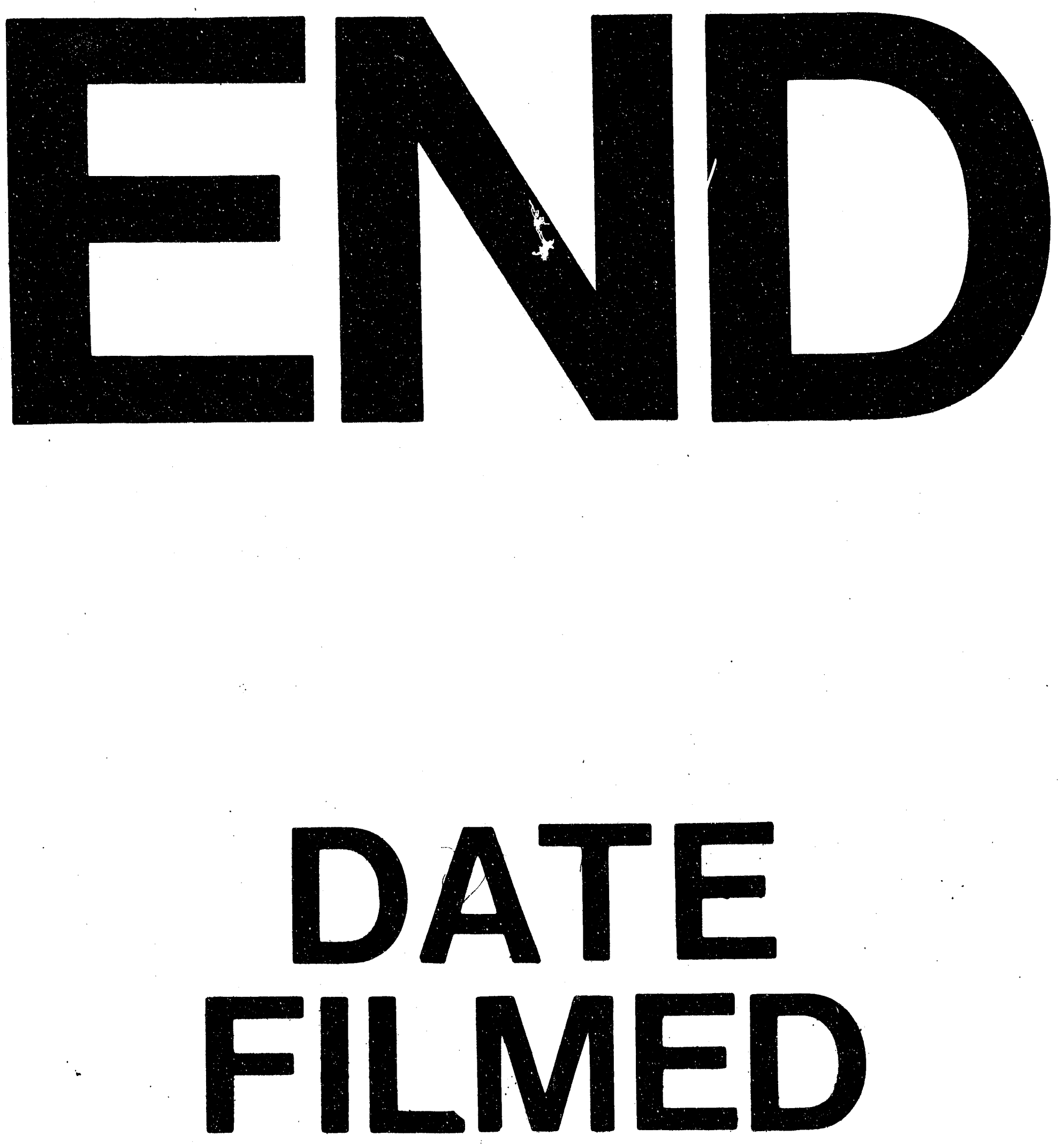

f

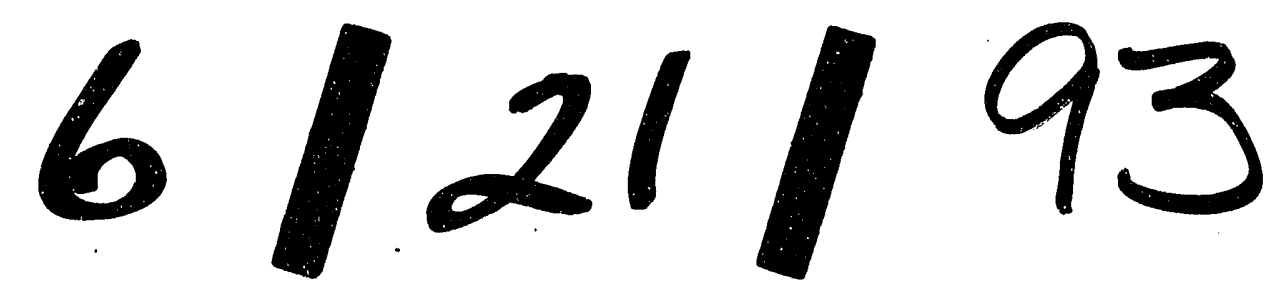


